\title{
STEELCITY LIVING: Hamilton, Stelco and the Post-industrial City
}

\author{
by \\ Desirae Cronsberry
}

A thesis submitted to the Faculty of Graduate and Postdoctoral Affairs in partial fulfillment of the requirements for the degree of

Master of Architecture

in

Azrieli School of Architecture

Carleton University

Ottawa, Ontario

(C) 2015

Desirae Cronsberry 



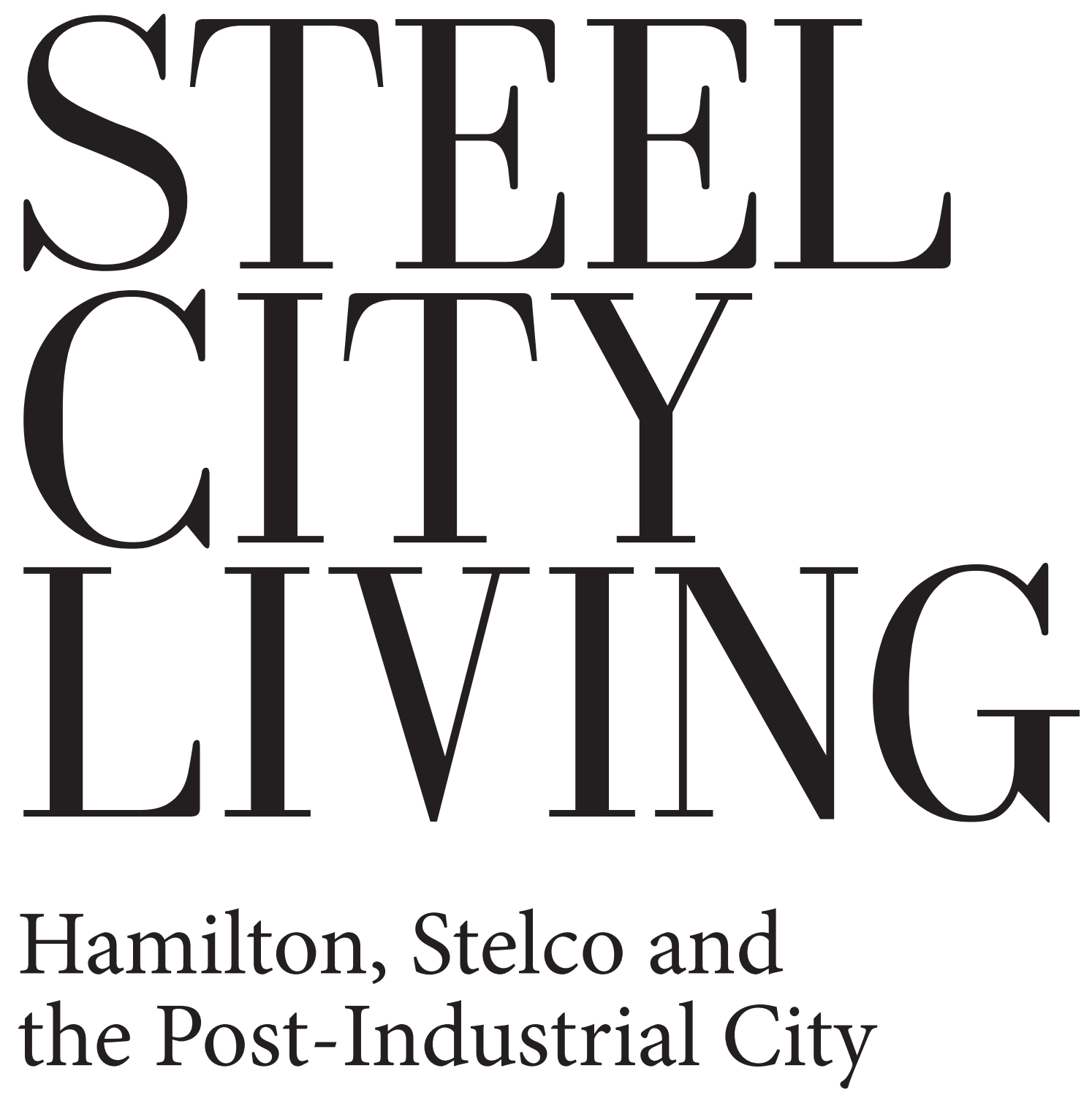


$\leq$

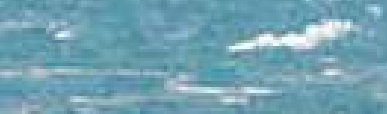

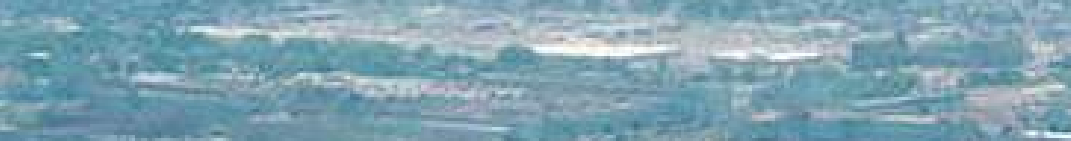

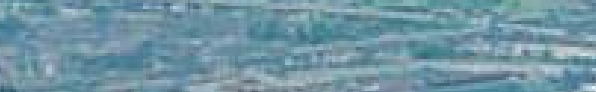

$\rightarrow$

$+2$

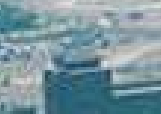

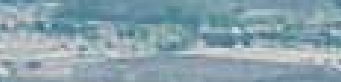

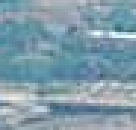

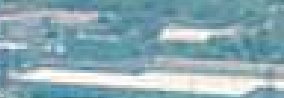

$\lim _{i=0}$

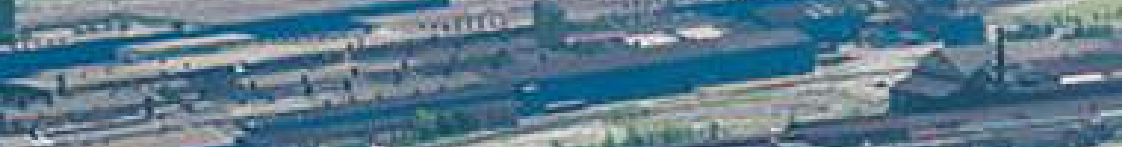
18. 5.

a

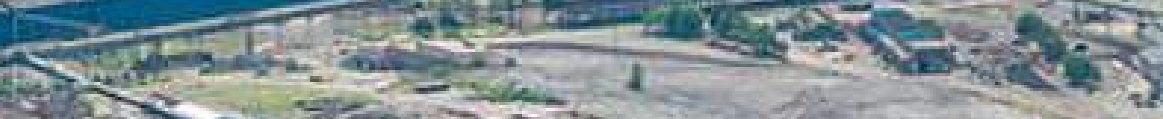

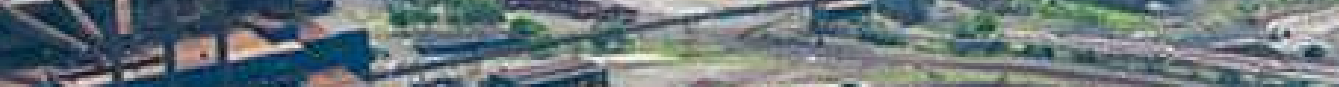

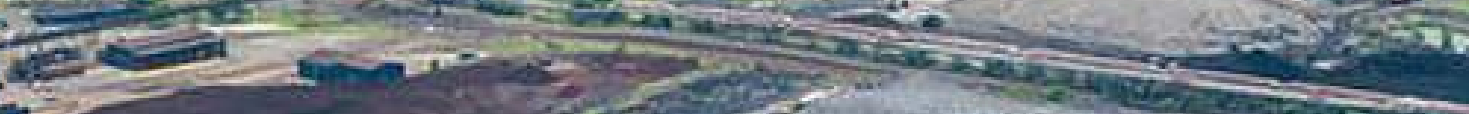<smiles>CCC#CC#CCCC</smiles>

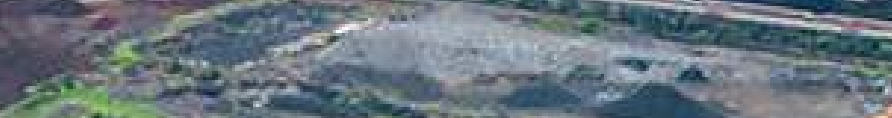
$\sin _{2}$ $m$ mak

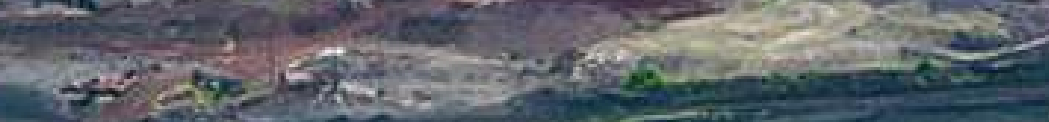

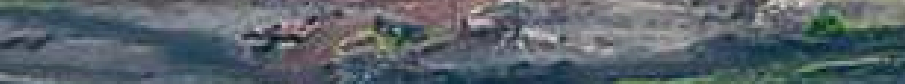

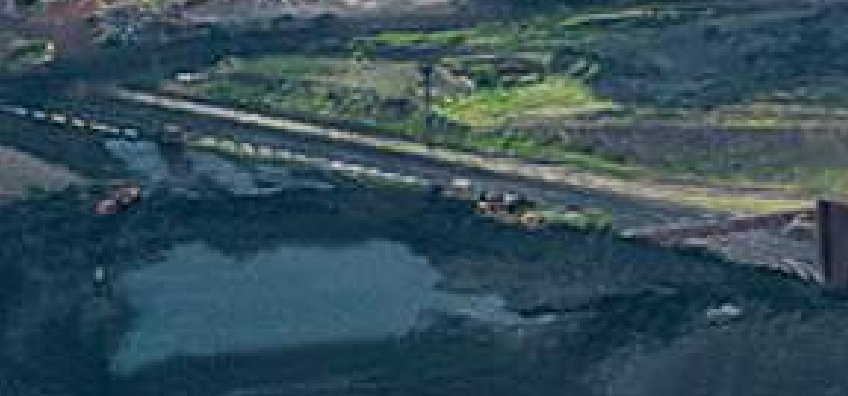

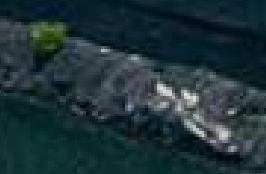
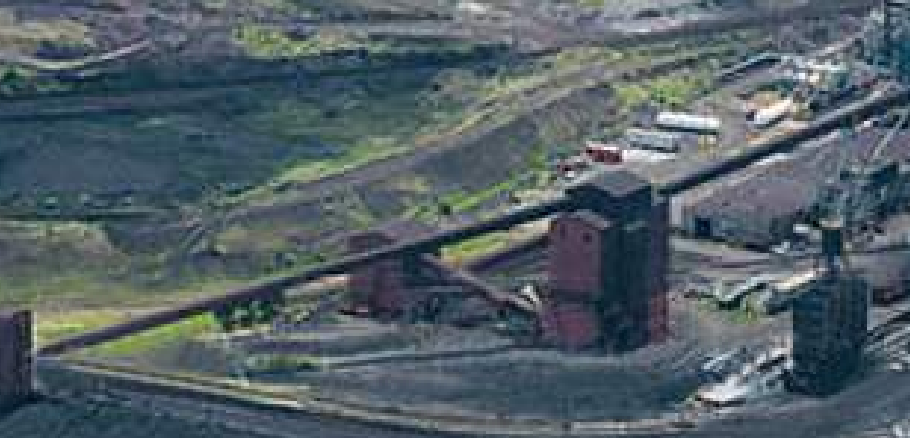

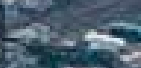
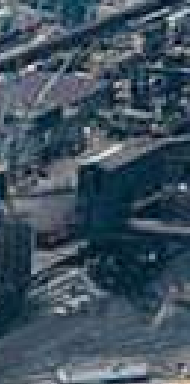

ins

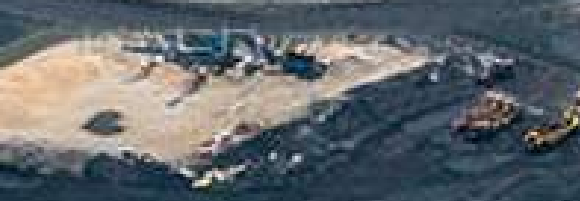

Sis:
interis
200303
e.8.4 

Fin

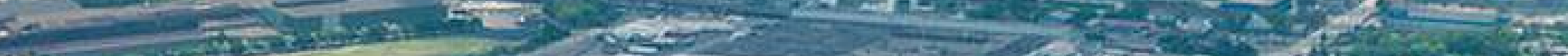

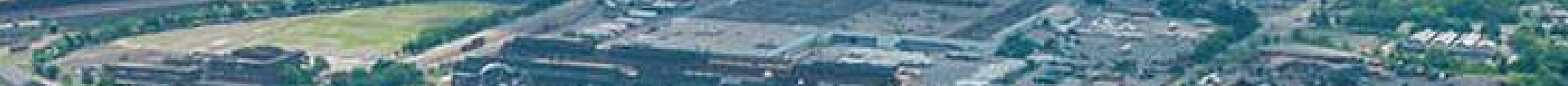

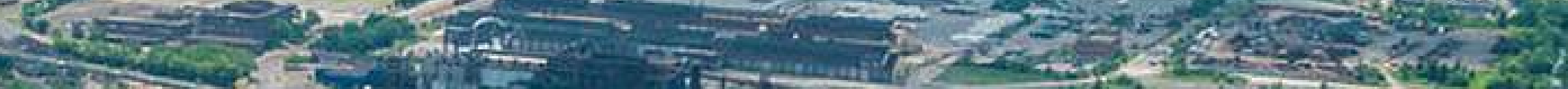

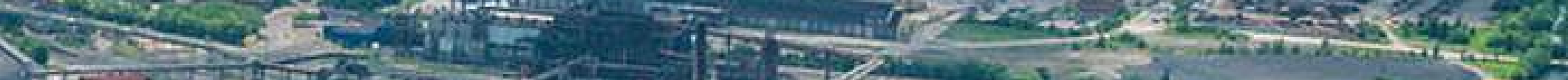

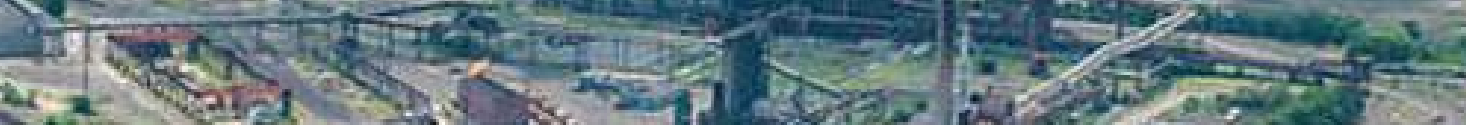

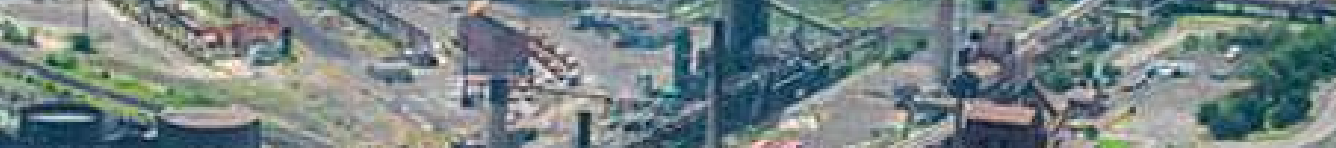

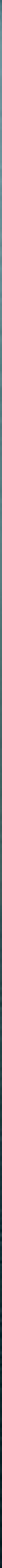





\begin{abstract}
Brownfield sites in Canada play an essential role in the future development of post-industrial cities. Fundamentally unproductive, these spaces are of no benefit to the city's recovery and therefore must be adapted for a new use. U.S. Steel Canada (Stelco) has defined Hamilton's economy and cultural identity as a blue collar city for more than a century. Now under bankruptcy protection and seeking potential buyers, concerns of the city's capacity to exist as an industrial based economy have increased. The growing inventory of brownfields and the demand for affordable housing in Hamilton are influential factors in its season of heightened urban renewal. SteelcityLivingseekstosetaprecedentfordevelopmentandaffordable housing enriched by the remediation and preservation of Stelco's industrial ruins and the significance of Hamilton's cultural past.
\end{abstract}



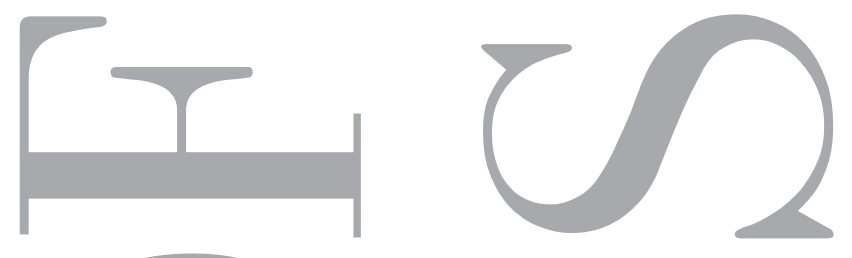

02
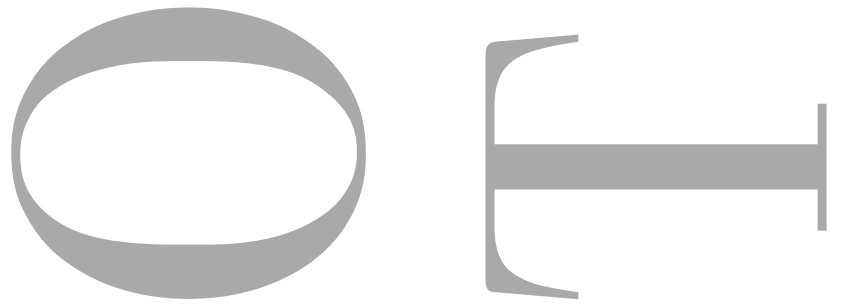

06

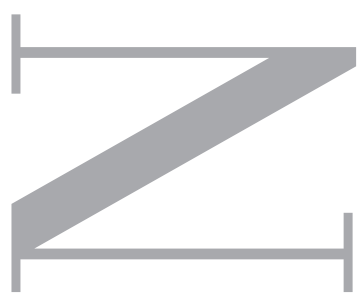

30

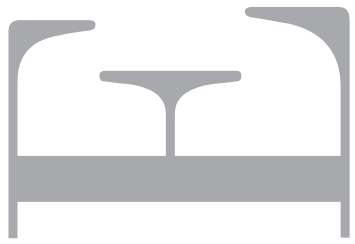

54
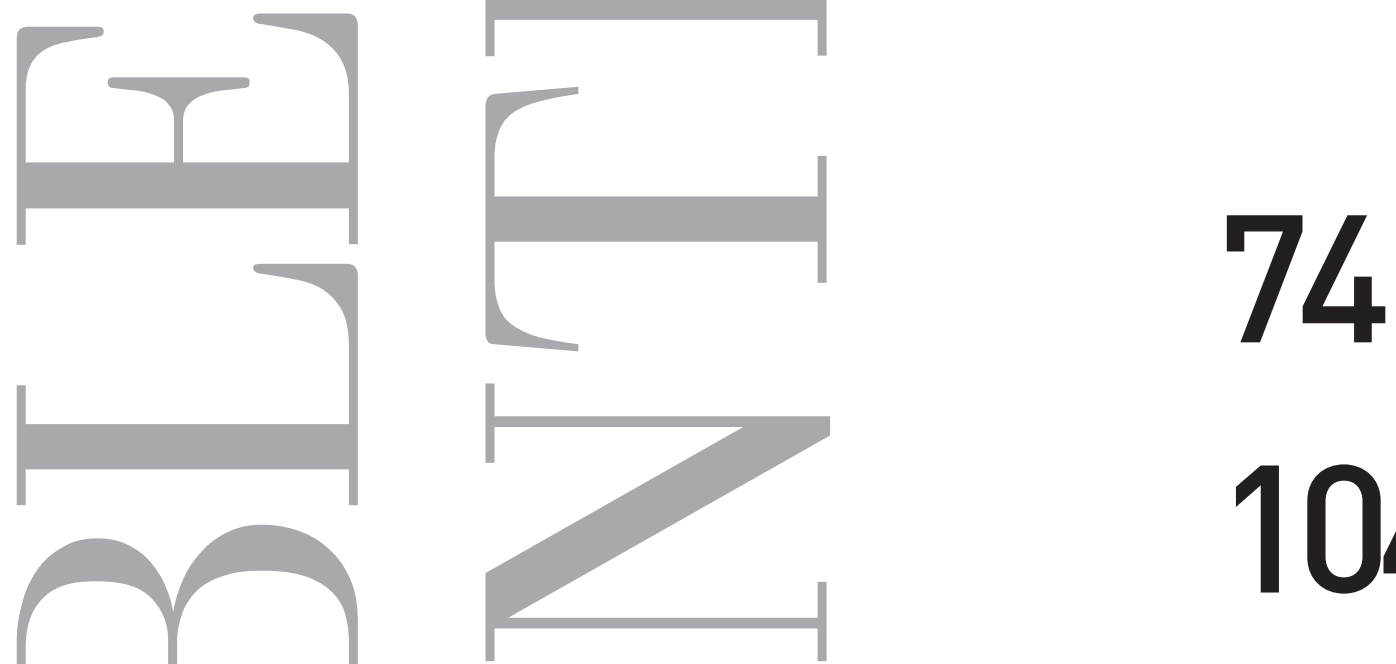

104
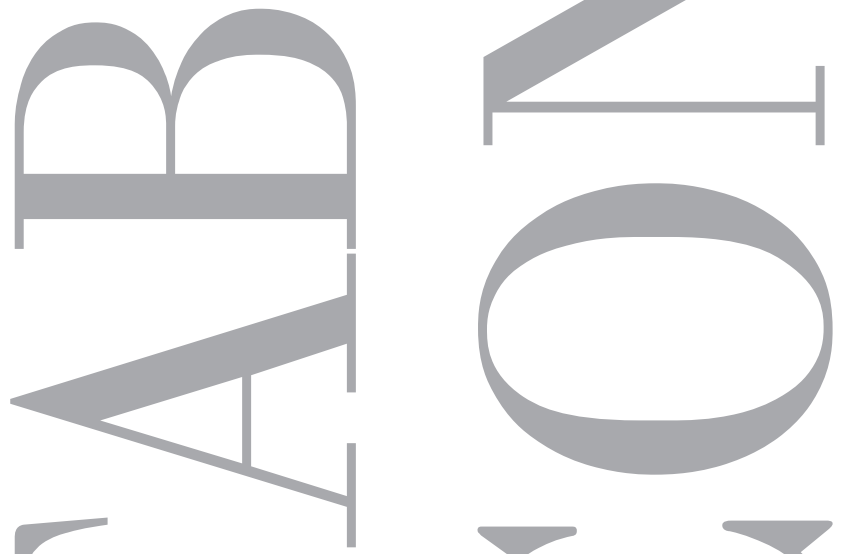

120
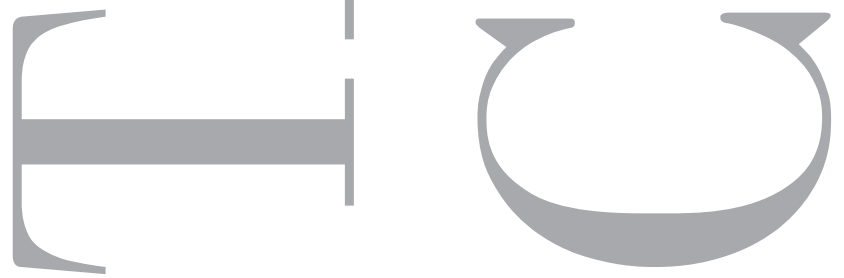

146 
RUST BELT CITIES

ChITY

Hammer Town

SITE

Stelco

$\underset{\text { Steelcity Living }}{\text { DESIGN }}$

LANDSCAPE

HAMILTON HOUSING

Affordable?

$\$ 100,000$ HOUSE

NEIGHBOURHOOD 


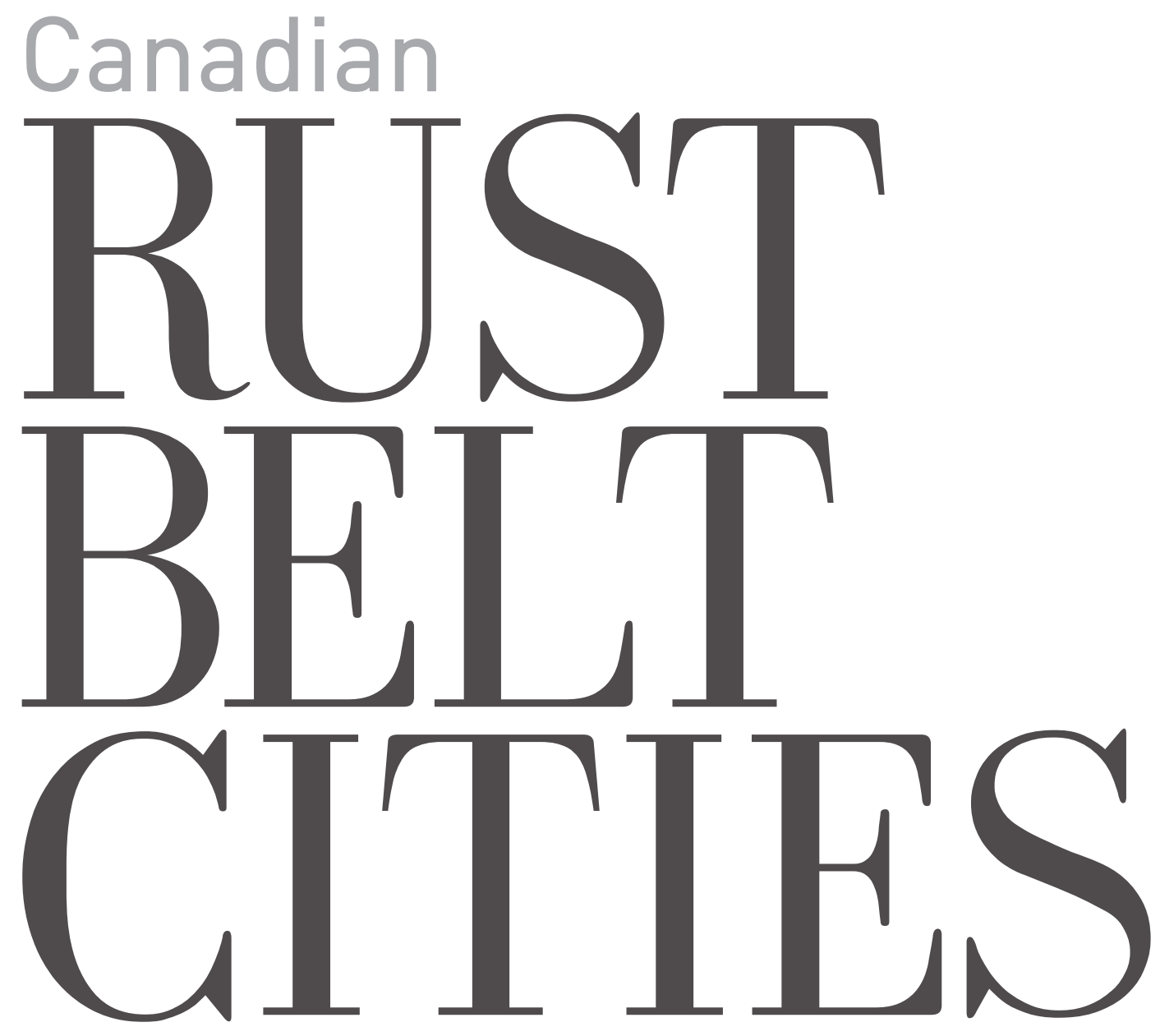


The Rust Belt cities of Canada are the new future. As young adults withdraw from the suburban neighbourhoods of urban sprawl and face the rising prices of major cities like Vancouver, Montreal and Toronto, post-industrial cities offer alternative opportunities to live, work, play and create a new sense of community in the bones of a once great blue-collar community. Previous manufacturing success has provided a strong cultural identity, low cost of living and a wealth of industrial ruins. As a city catapulted into a season of urban renewal, opportunities to lead in the rebuilding process are abundant. Development is driven by the capitalization of existing identity rather than creating a new one. Not all the characteristics that encourage gentrification are so tangible. Beyond government funding, densification policies and comparatively affordable housing, the rebirth of the post-industrial city requires something more emotional. A big part of the rebuilding is the strong sense of cultural identity, as a blue-collar city restoring pride in places where it has been lost.

On the most western point of Lake Ontario, and only a 45 minute drive away from Toronto, Hamilton is at the crux of a transition from a city formed by heavy industry to one of significant urban renewal. The growing vacancy of brownfields and housing demand are influential factors for this process of urban renewal. This project, Steelcity Living focuses on the development of the former Canadian steel giant, Stelco, now under bankruptcy protection and seeking to sell its vacant land. The century old factory holds the largest and most sought after industrial real estate in Hamilton. Leveraging the site's urban location, waterfront access and sublime scale this project seeks to set a precedent for affordable housing ownership and the conscientious brownfield development in Canadian post-industrial cities. 


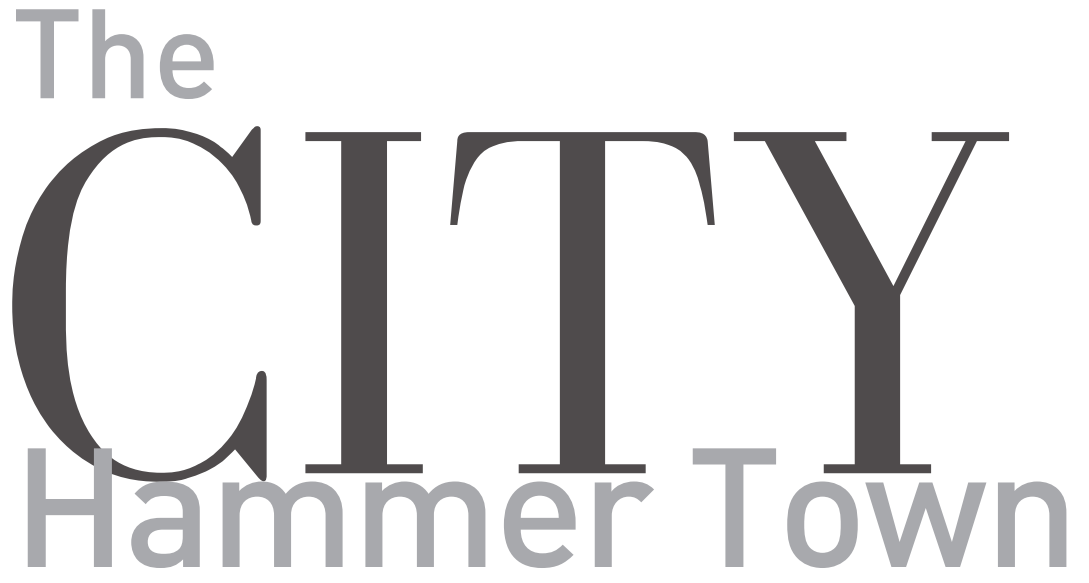

06 

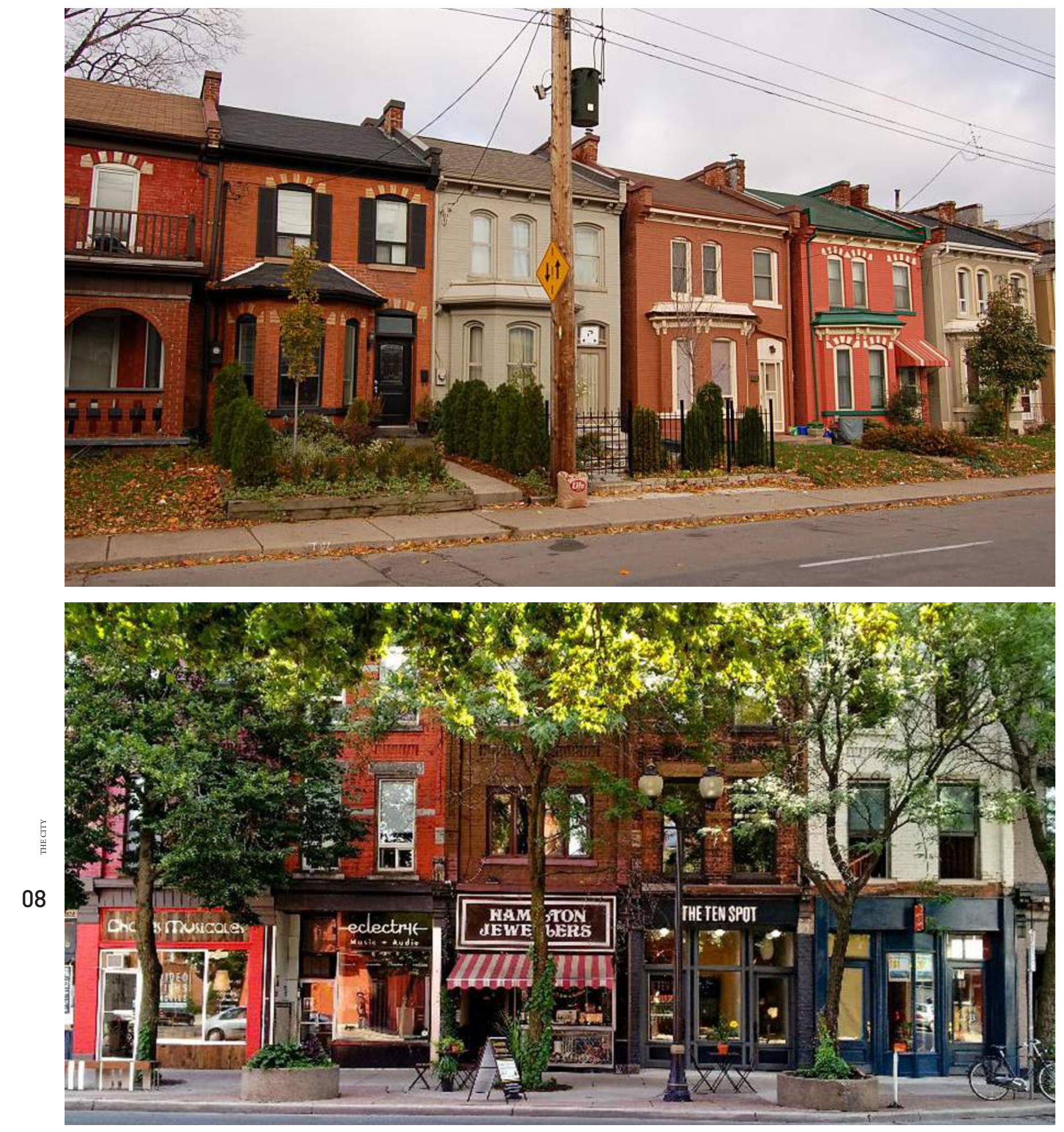

HAMILTON, JAMES STREET NORTH 

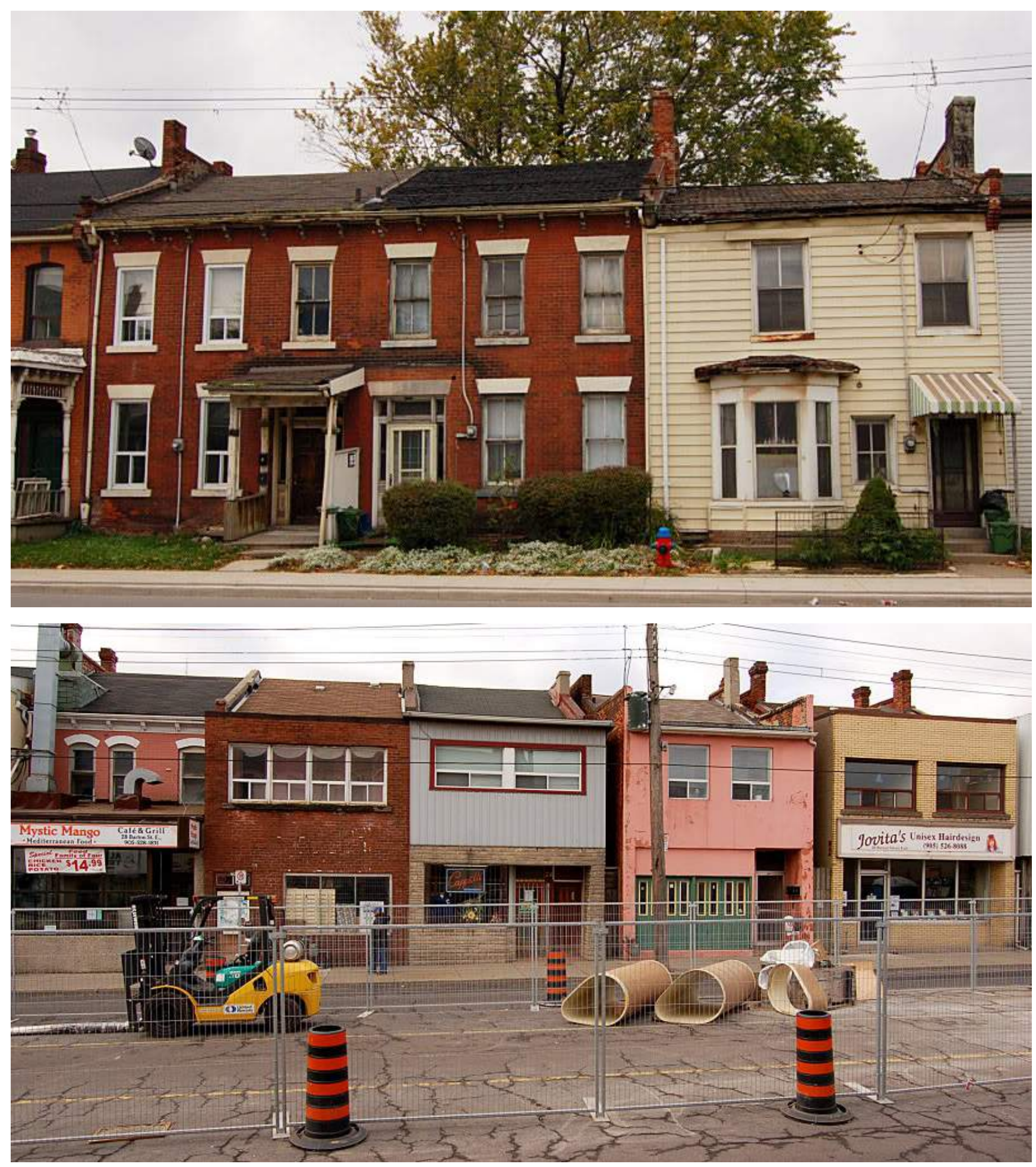

HAMILTON, BARTON STREET 


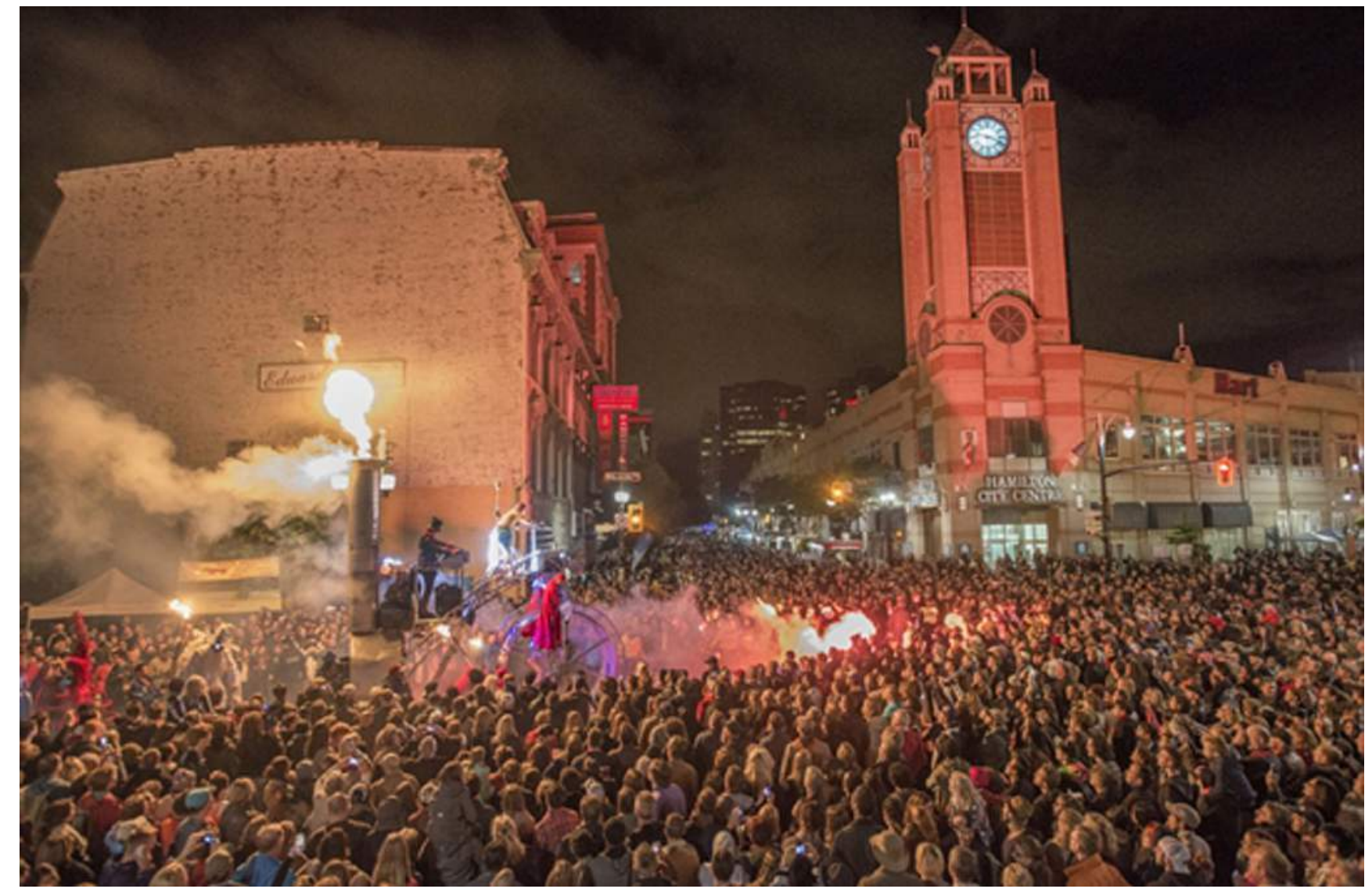

\section{SUPER CRAWL (SEPTEMBER 2014)}

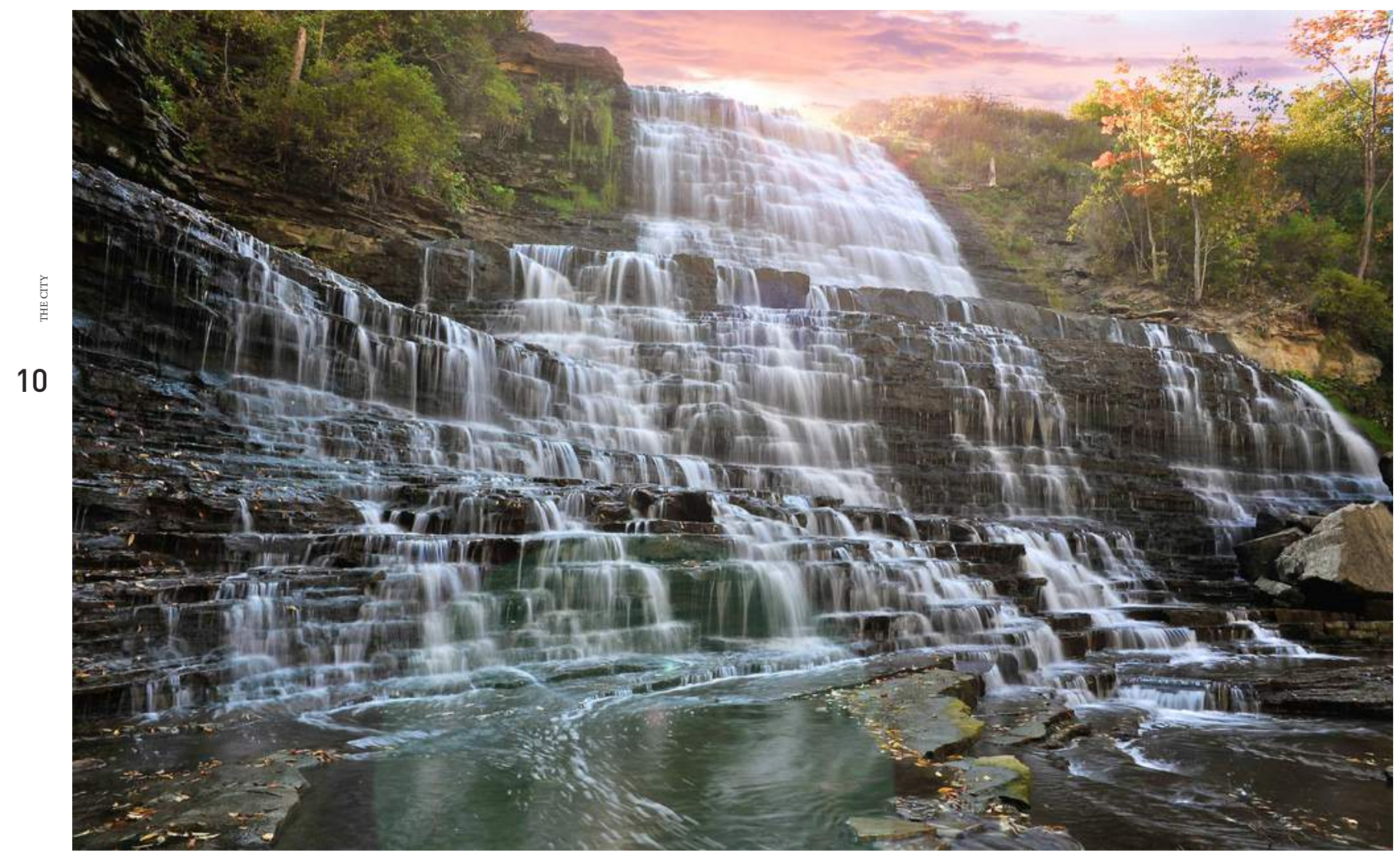




\section{Hamilton, Ontario}

Hamilton, like many other North American cities, has its share of industry to credit its historical development. Concerns of the Hammer Town's ongoing capacity to exist as an industrial economy have grown over the past decade. It is a present case of social and political worry as a post-industrial city.

In reality, an interest in the arts has become noticeable. Unplanned gentrification of the city's downtown has spurred a collection of local businesses, including art galleries, coffee shops, restaurants and vintage shops. New events such as the Juno Awards, Soup Fest, Super Crawl, Because Beer and Street Meat festivals have highlighted this surge in social culture. As the host of the 2015 Ontario Association of Architects (OAA) annual conference, Hamilton is upheld as a prototype for urban renewal, "currently transitioning from a manufacturing steel town to a vibrant arts and livable community. There is an overall energy in the city that is fervently seeking urban change." This recognition from a prestigious group like the OAA, marks a turning point in the development of the city, changes over the past decade have not only had a positive impact on the community but also levitated the position of Hamilton as an active contributor to the Great Toronto Area. This drastic urban development is due in part to the influx of out-of-town buyers. Compared to Toronto and the rest of the Greater Toronto Area, Hamilton is a more affordable market for first-time homebuyers, small business owners, and a younger generation seeking cheaper rents. The accessibility of Hamilton's downtown core to Toronto via the Go Train provides an ideal scenario for individuals to commute to and from work. The affordable market and the seemingly endless possibilities for growth and rejuvenation attract new homeowners, and native residents to participate in their emergent community.

Hamilton as a rust-belt city presents a unique set of characteristics that over time has shaped its physical development. Abundant in industry and diverse natural landscapes, these markers have shaped the city's urban morphology. One of the most beautiful characteristics is the city's extensive list of waterfalls, most of which are along the Bruce trail winding through the Niagara escarpment. This feature is at responsible for the title 'City of Waterfalls'. However, Hamilton's industry has been the source of most nicknames, including Hammer Town and Steelcity. The significance of industry for Hamilton's development is irrefutable, led by the Canadian steel giant Stelco. 

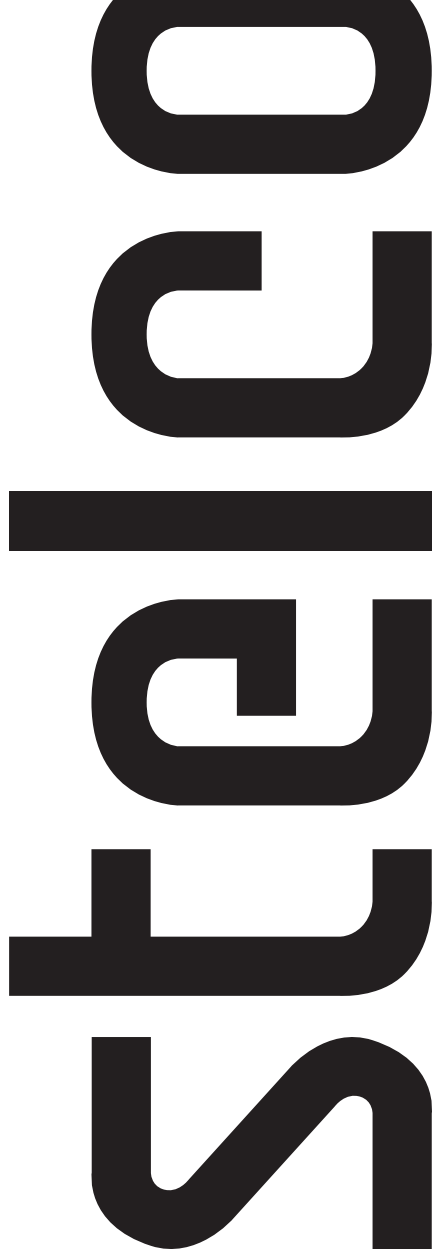
In Hamilton, U.S. Steel Canada (formerly known as Stelco) holds the largest and most sought after industrial real estate. The U.S. Steel plant, approximately 4.5 square kilometers, runs along the city's waterfront to the Hamilton Harbour. Much of the current land is infill, built up over the last century. Described by former Hamilton mayor Victor K. Copps as the "mother hen of the nest", Stelco's presence in Hamilton is palpable. The company's physical placement occupies four linear kilometers of the city's industrial waterfront. From the Skyway Bridge, the site acts as the iconic gateway for the city while travelling on the QEW highway that stretches from Toronto to Niagara Falls. At peak production, 10\% of the city's population was made up of families and dependents of Stelco employees. Any union conflicts directly affected the moral of the citizens, even if one was not financially dependent on the company. Gulturally, the company contributed to the city's identity as a blue-collar community. Unsurprisingly, the demise of the company in the last decade is not a pill easily swallowed by Hamiltonians, especially since the American company U.S. Steel purchased the plant eight years ago. In October 2013, U.S. Steel Canada made the announcement that shocked the city of Hamilton: the "United States Steel Corp. will permanently cease steel production at its Hamilton mill at the end of the year, ending an era that goes back more than a century."’2 By contrast, Stelco's neighbour, ArcelorMittal Dofasco, achieved a shipment record in steel production the very same week Stelco announced its partial closure. Stelco's location is partially credited for its sustained presence as a Canadian steel giant for a long time, proving to be beneficial during the hard times. However, as the steel industry shifted to a global market large Canadian companies struggled to remain innovative and provide affordable products. 

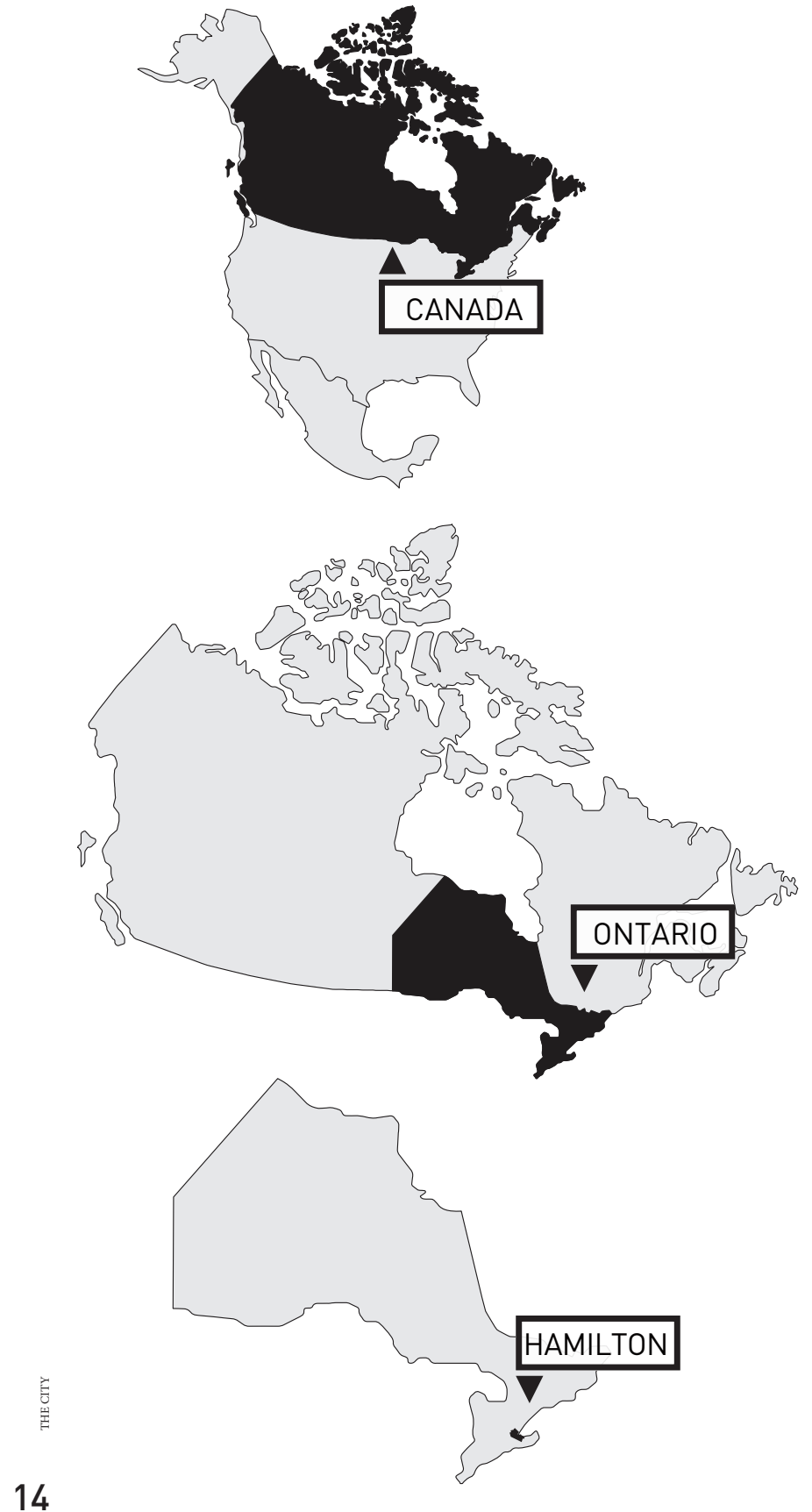

14

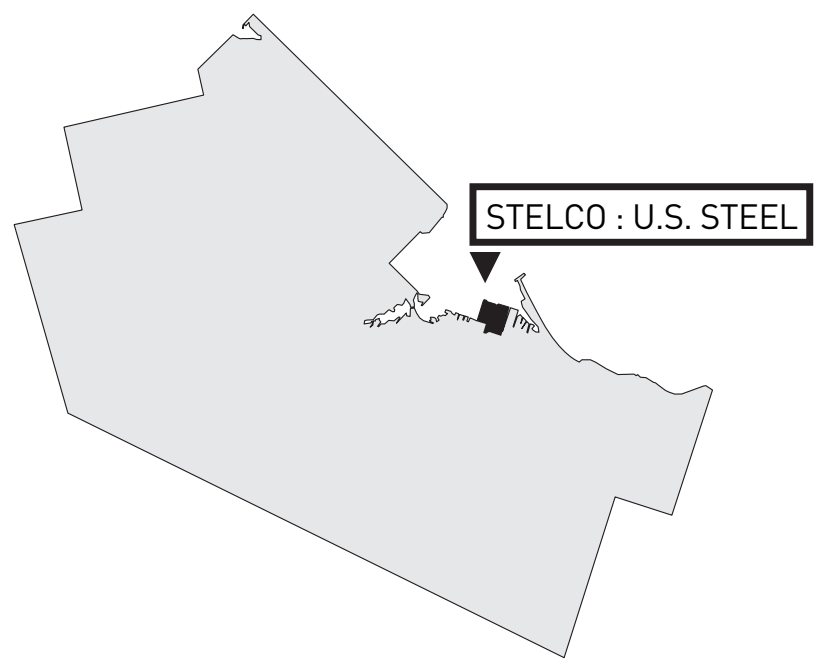

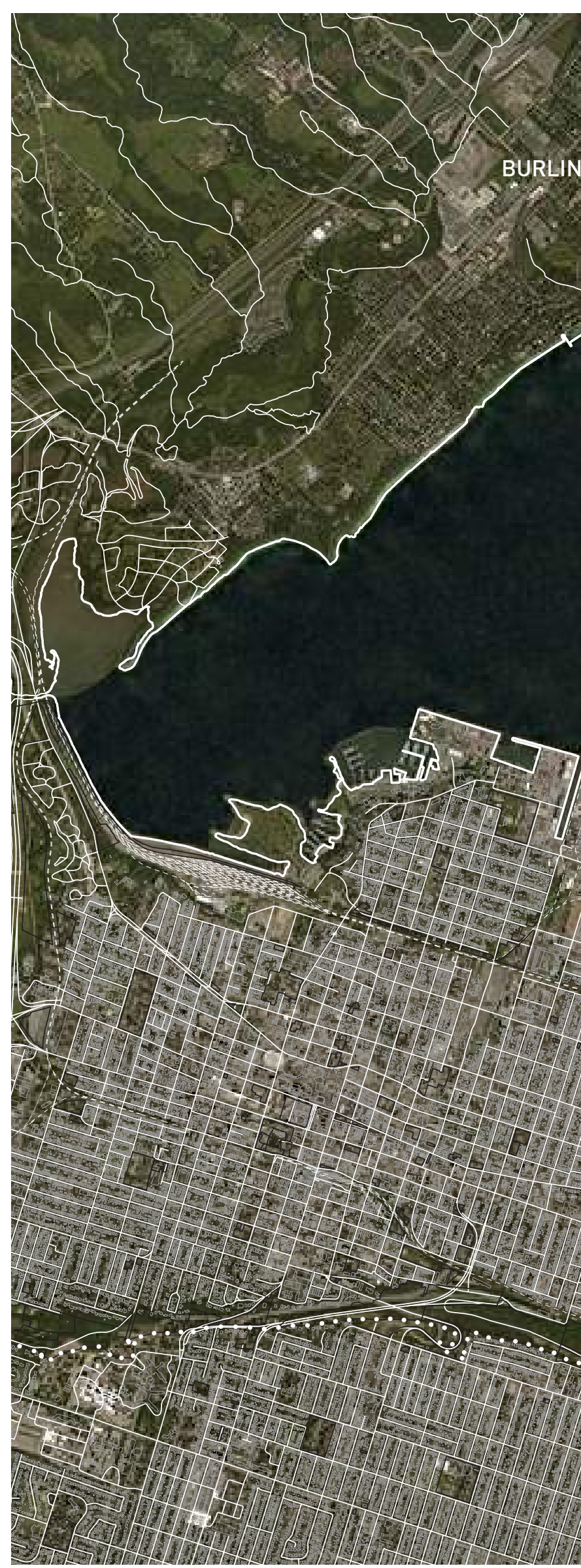




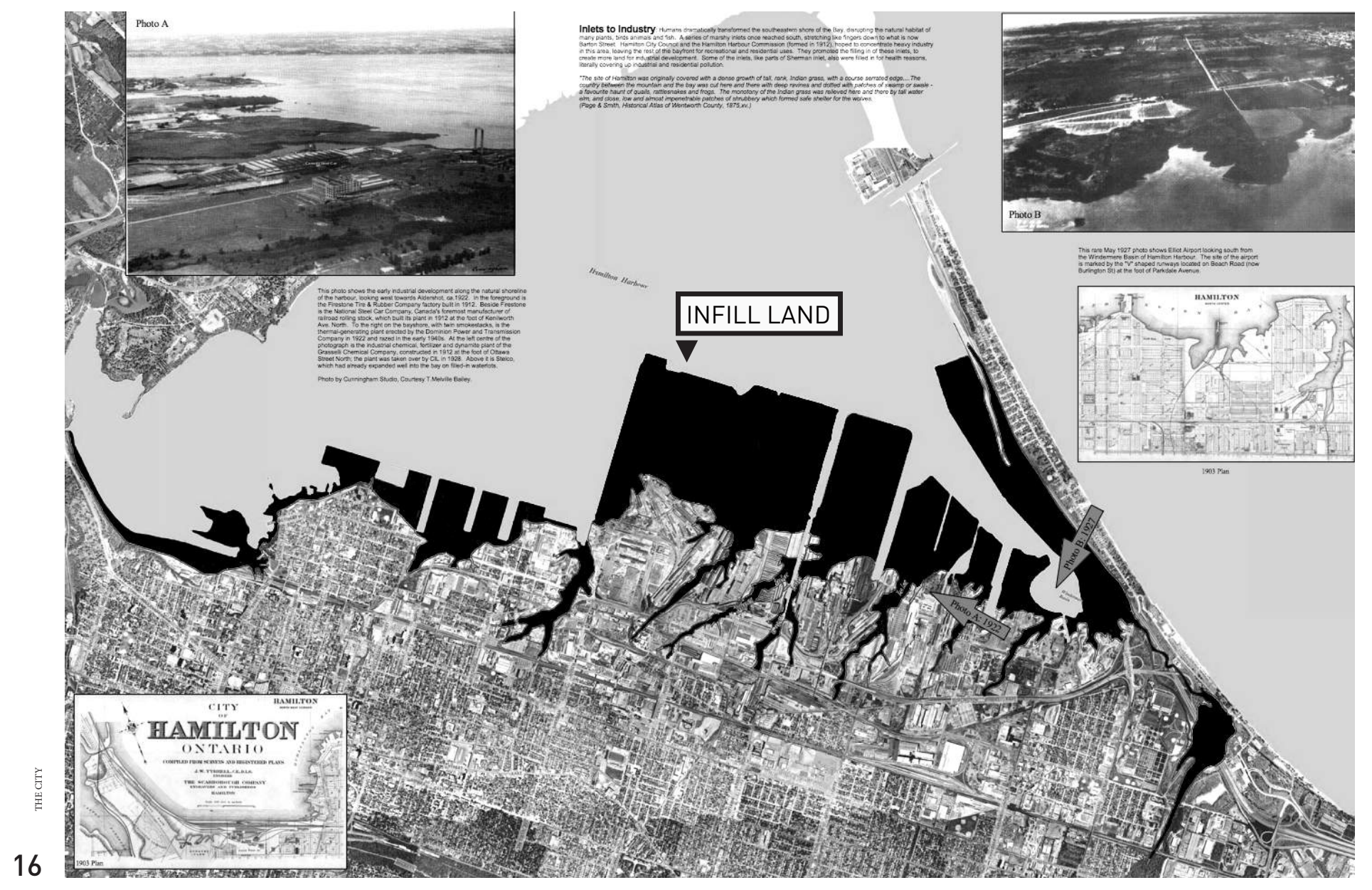

HAMILTON INFILL 


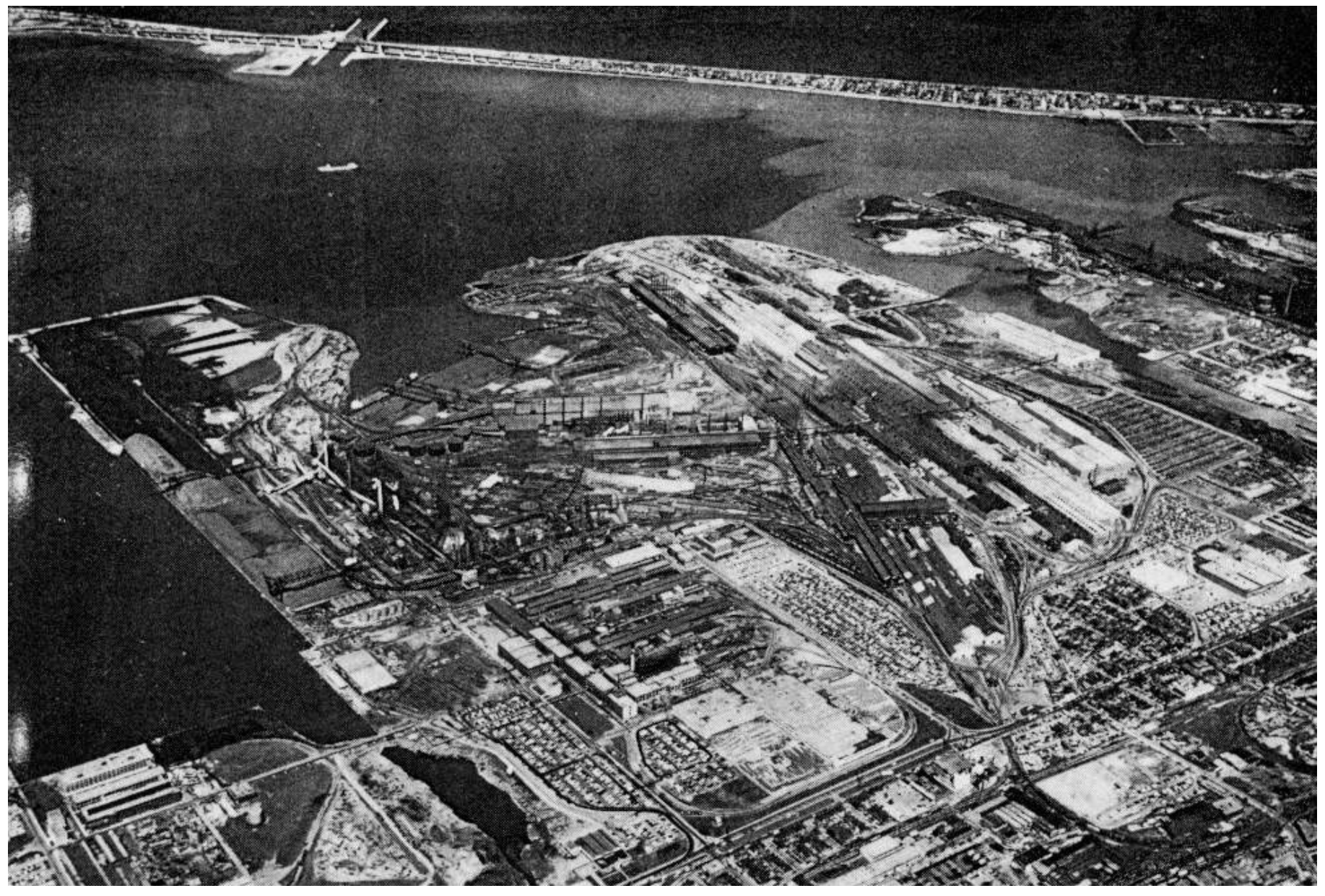




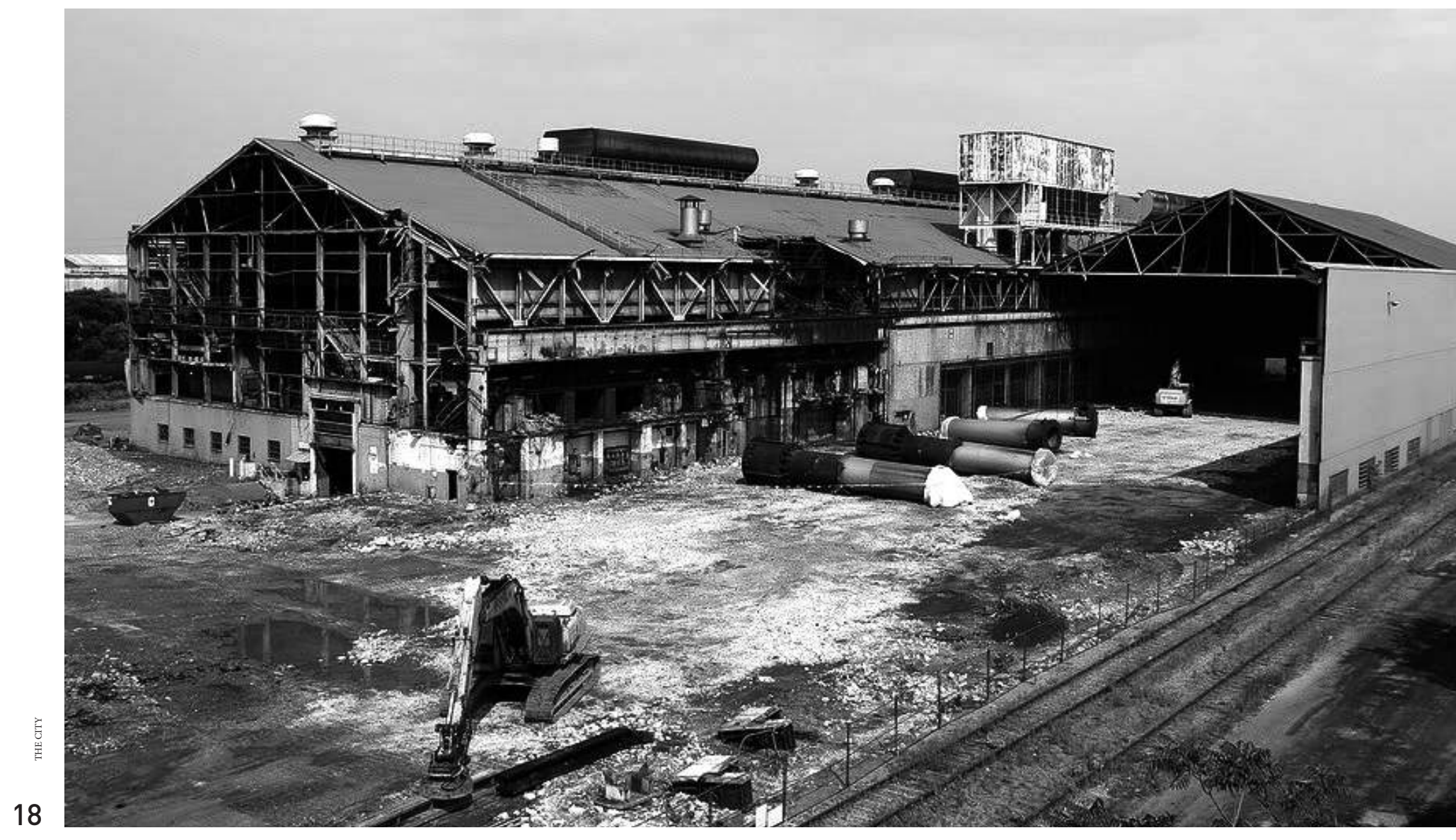

STELCO No. 2 ROD MILL 2008 


\section{Brownfield Sites}

In 2012 Canada imported nearly $\$ 4.6$ billion more in steel than it exported. ${ }^{3}$ For a country built upon its seemingly endless supply of natural resources in recent history the ability to remain competitive in the global market is decreasing. Many of these industrialized landscapes, literally the factory sites, that shaped our blue-collar cities are now threatened with vacancy, exemplified by the recent troubles of US Steel Canada. With such a lasting footprint on the city of Hamilton, along with the cultural implications that such a transition has, the prospect of redevelopment of the waters edge is an essential discussion for the city's future.

The imprint of Hamilton's steel industry is irrefutable in its physical development and social history as a blue-collar community and should influence the future design of the Stelco site. The physical form of development for brownfields is subjective however the decision to develop is that of necessity. The NRTEE (National Round Table for the Environment and the Economy) Brownfield Strategy defines brownfields as "abandoned, idle or underutilized commercial or industrial properties where past actions have caused known or suspected environmental contamination, but where there is an active potential for redevelopment." 4 Brownfield sites are an immensely valuable resource for the city's changing future. Many of these sites provide untapped potential in urban environments where development is unlikely due to building density. Fundamentally unproductive, brownfield sites are of no benefit to the growth and development of a city unless adapted for a new use. 


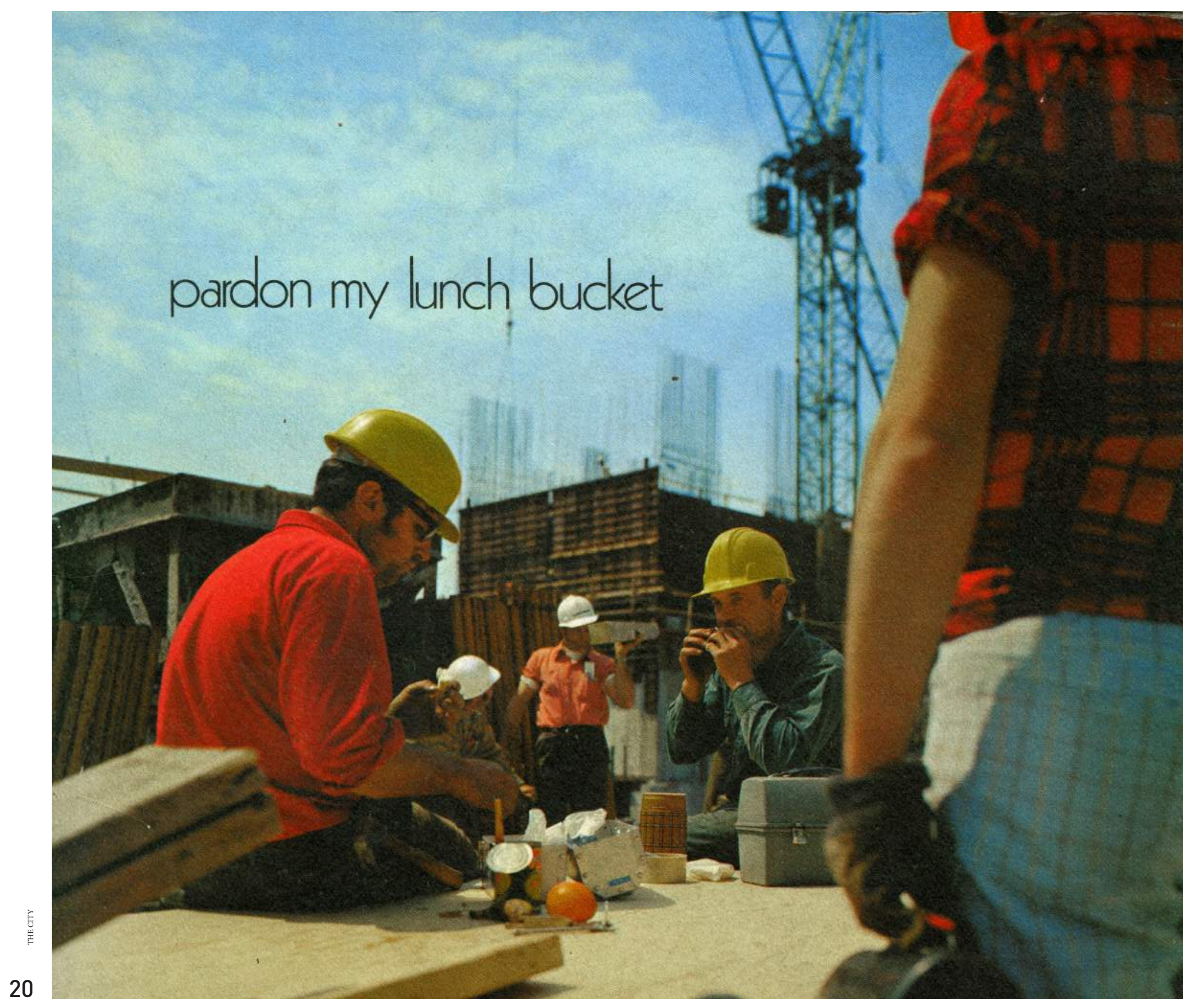




\section{pardon my lunch bucket}

Pardon My Lunch Bucket is a book published by the City of Hamilton on its $125^{\text {th }}$ anniversary in 1970. The book celebrates Hamilton's historical achievements and the vibrant city it had become. At the time it was written extreme development was underway in the city's downtown. Influenced by the megastructures of the 1960s, Hamilton demolished large downtown blocks to created the unfortunately iconic Copps Coliseum and the Lloyd D. Jackson Square. Copps's desire to transform the city from blue collar to white collar enabled many projects like the massive Jackson Square that eliminated multiple blocks of low-rise development and essential circulation. The book optimistically envisioned a future city independent from the crutch of heavy industry to catapult itself to the world stage. Although Pardon My Lunch Bucket, anticipated the smoke from the steel factories to fade away, Hamilton has proven to reinvent itself as a culturally rich and liveable community through urban renewal despite the continued presence of industry. The mayor of Hamilton, Victor K. Copps, wrote the forward to Pardon my Lunch Bucket.

I don't particularly mind Hamilton being called a lunch-bucket city. It's no crime to take your lunch bucket to work. There's nothing indecent in getting your hands dirty in the foundry or rolling mill, making a decent living so you can bring up one of those large families that steel workers are so fond of.

So Hamilton has industry. So what? A good industry base means jobs - solid, career opportunities for the citizens of this city - jobs they can count on so they can plan ahead for their families.

The old lunch-bucket, like the glass milk bottle of a few years ago, is destined to become a museum piece, something that us old-timers can take our grandchildren to see one of these days to point out the way it used to be.

With its industrial base and its ever-expanding residential areas, Hamilton has a brilliant future ahead of it as a place to live, to work, to grow up in, to expand your personal horizons as the city expands hers. Only one thing worries me now. If the lunch-bucket tag becomes passé, what are Hamilton's critics going to come up with to replace it? ${ }^{5}$ 


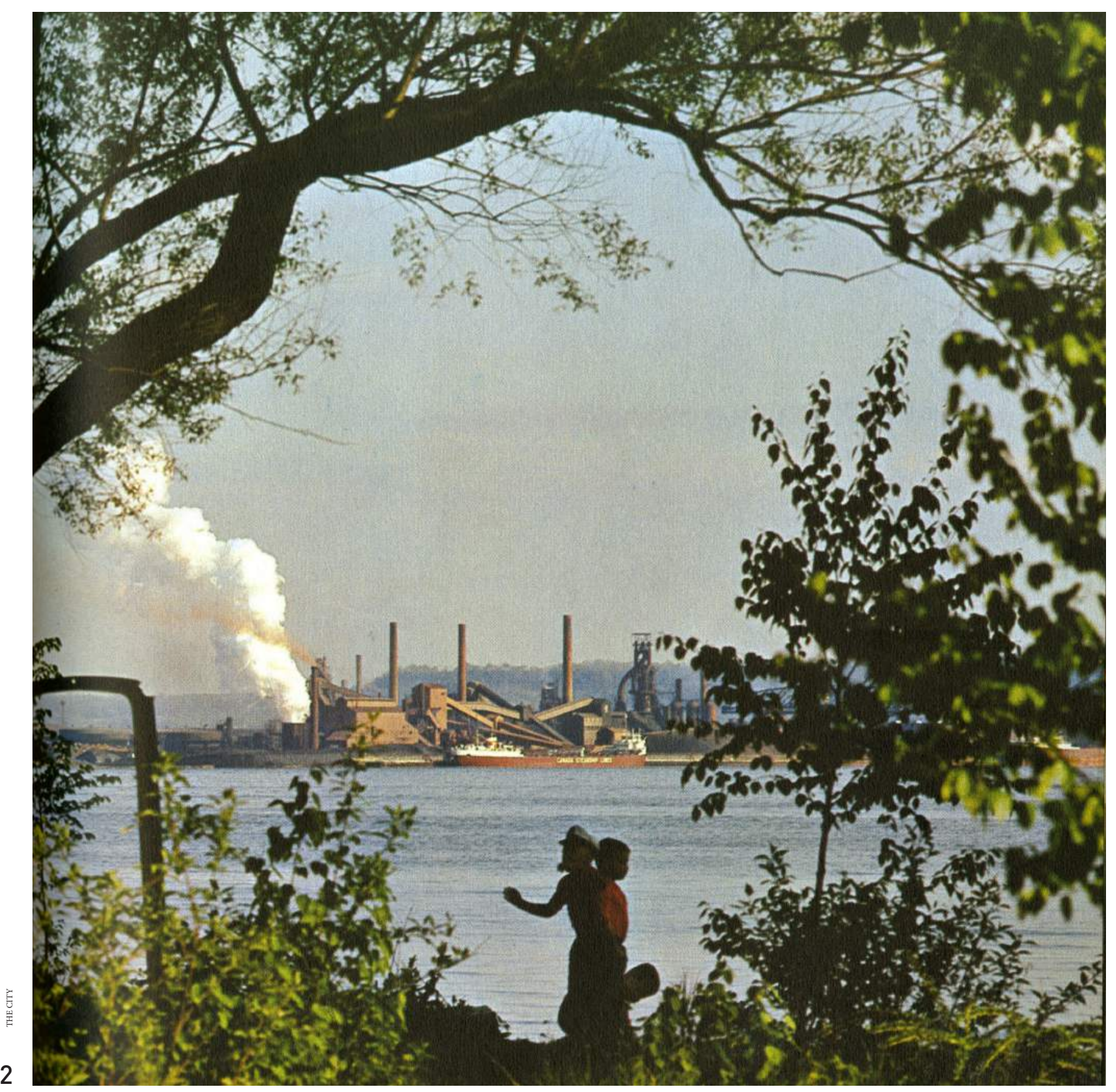

HAMILTON HARBOUR 


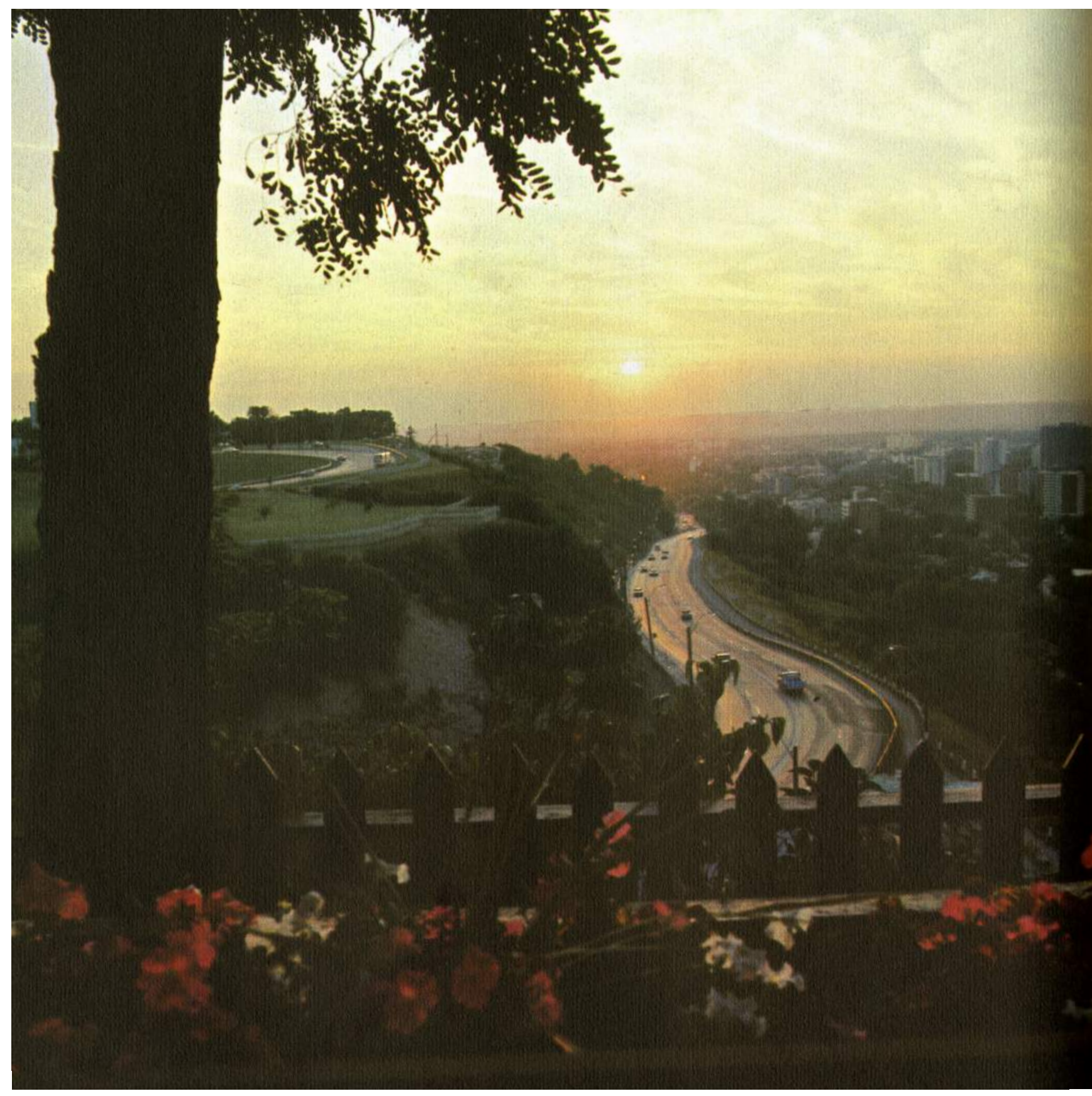

HAMILTON ESCARPMENT - "MOUNTAIN BROW" 


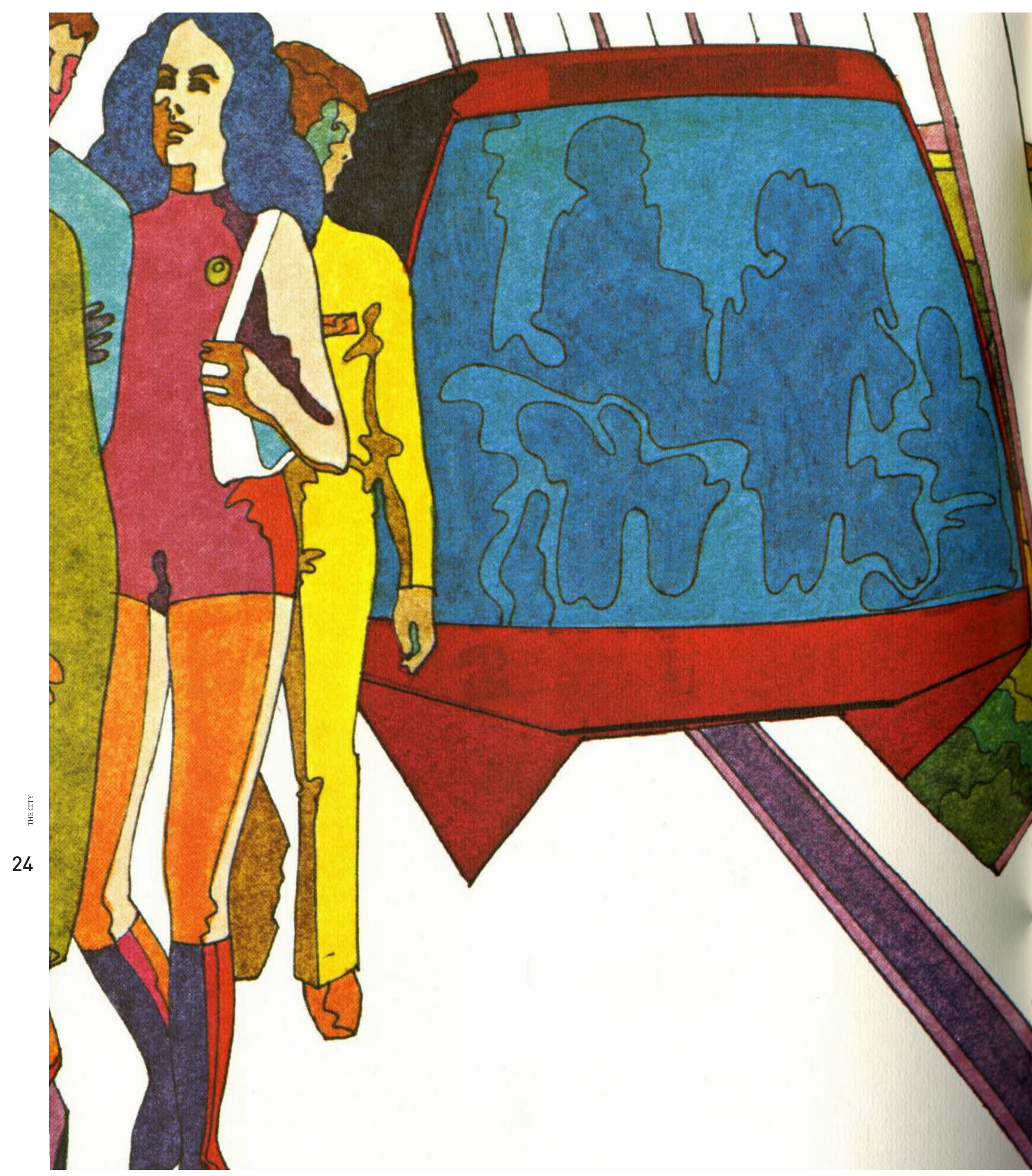

“JET POWERED MONORAIL GLIDES INTO MOUNTAIN BROW STATION." 


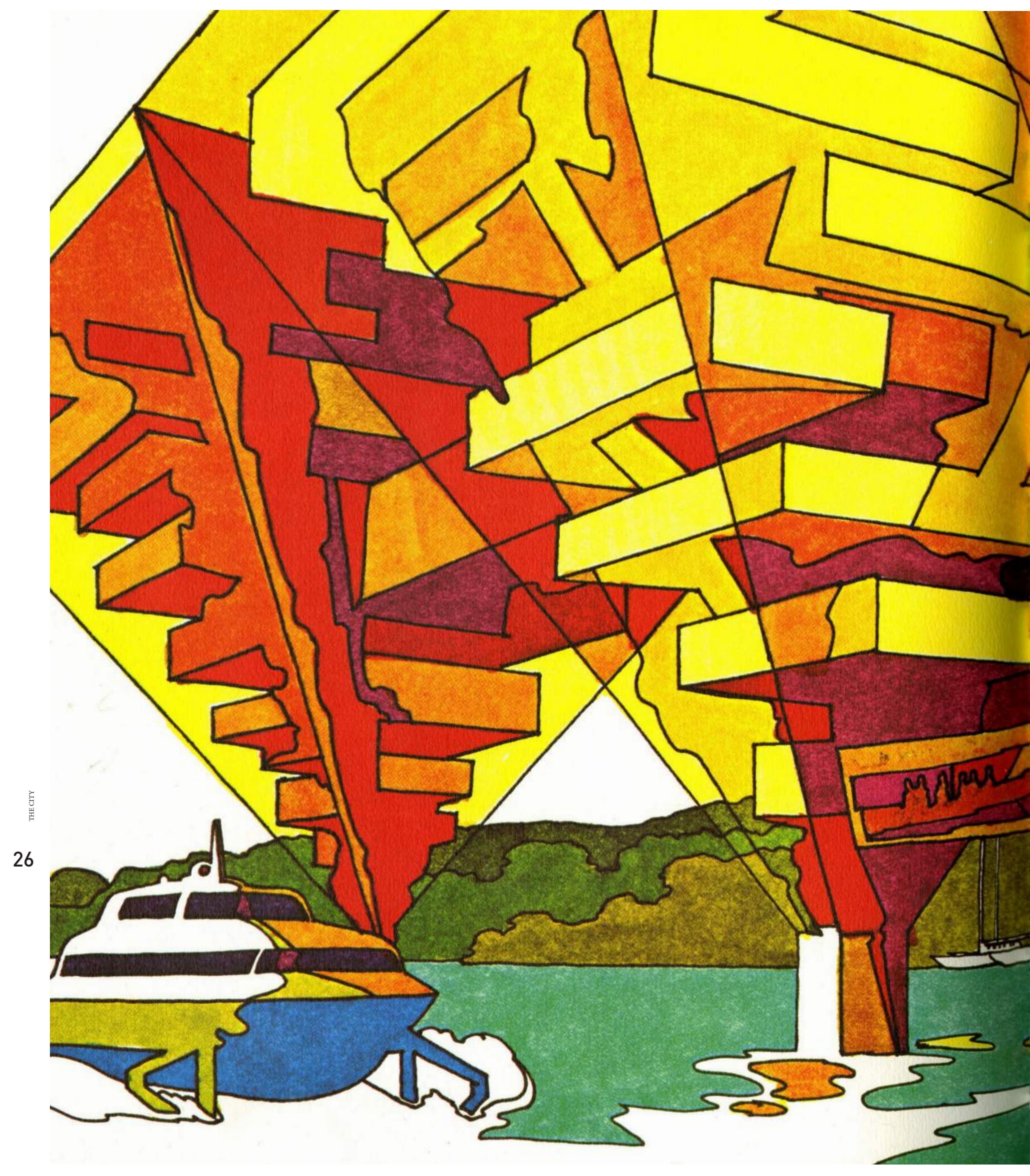

“HIGH RISES IN YEAR 200, WITH HYDROFOIL WATER TAXI SERVICE.” 


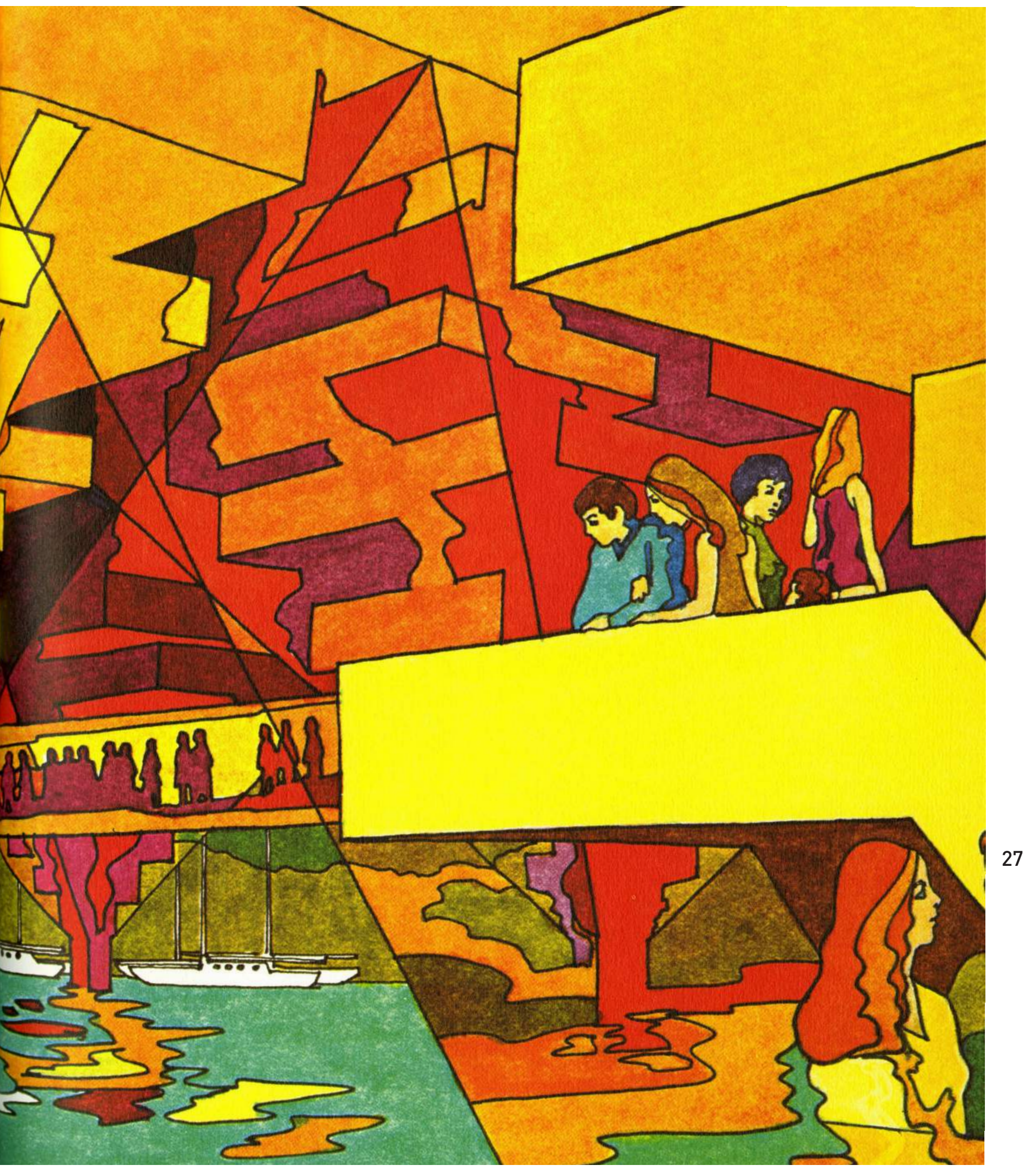


1 “OAA Annual Conference 2015,” OAA, accessed March 17, 2015, http://www.oaa.on.ca/news.

2 Greg Keenan, "U.S. Steel end an era in Hamilton," The Globe and Mail, October 29, 2013.

3 Marty Warren and Leo W. Gerard, "Canada Needs a Steel Strategy," Financial Post, November 5, 2013.

4 OCETA, "States of Canada's Brownfield Redevelopment Industry," Canadian Brownfields Network (2008): 5.

5 David Proulx. Pardon My Lunch Bucket (Hamilton: The Corporation of the City of Hamilton, 1970) : n.p. 


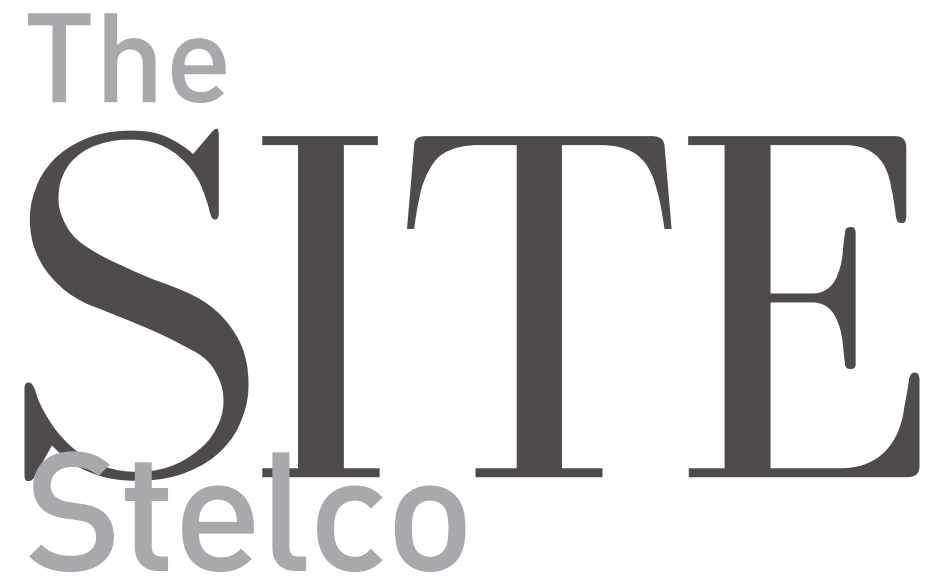




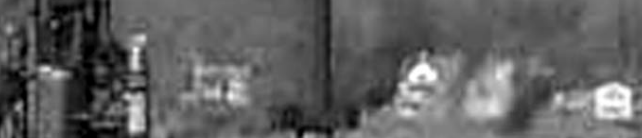
(1)

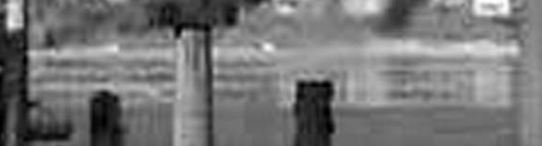

盾

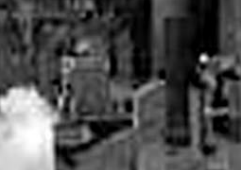

Li 1 in

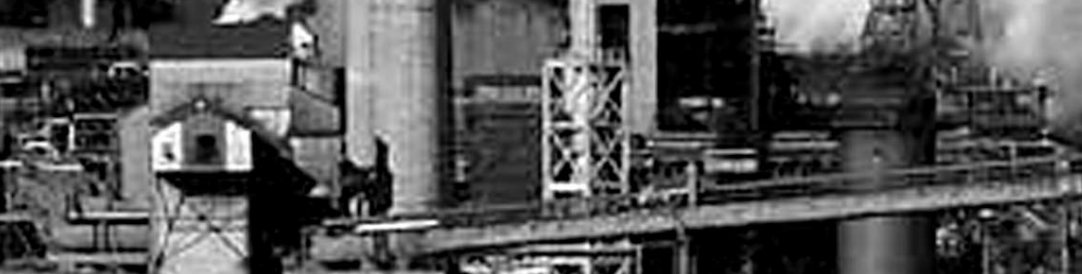

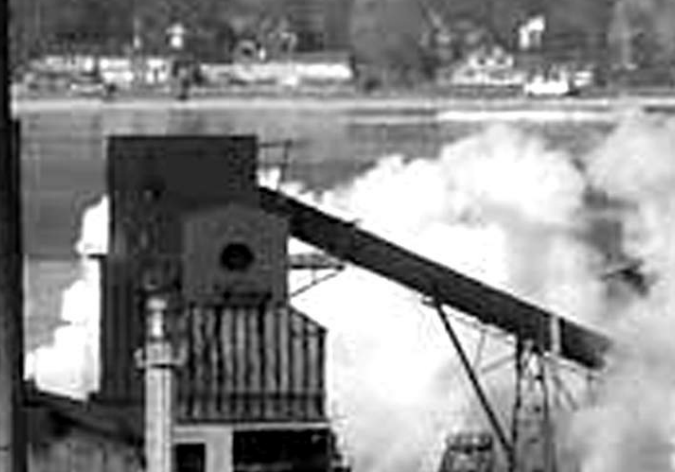

갖․…

3)

ins

4.

$\frac{2}{8}$

min teditio

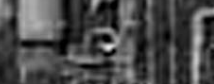
ai)

新

Nas

if

m.

incis

if

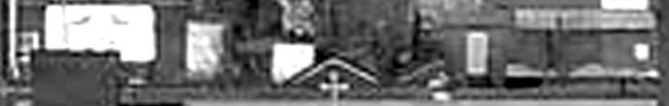

${ }_{0}=20$

xas? in

$1 x^{n}=0$

7 ina

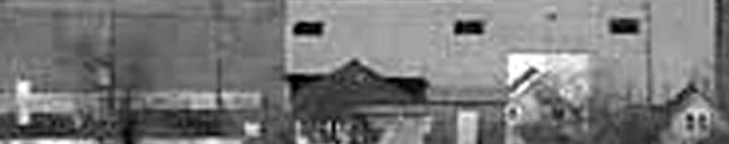

3ㄴ.

A 3 ing rexing:

ax: सम 


\section{History of the Industrial Sublime}

The North American sublime initially evolved from European ideas in literature, philosophy and art. The sublime was depicted in stories, paintings and theatres as a concept of the human imagination. The American sublime however found potency in the overwhelming nature of its environment. The emotions present in experiencing this new sublime were not unlike those expressed by Edmund Burke in the $18^{\text {th }}$ century. Burke describes the necessity of fear to achieve this overwhelming feeling: "Whatever is fitted in any sort to excite the ideas of pain and danger... is a source of the sublime; that is, it is a productive of the strongest emotion which the mind is capable of feeling." This sense of awe continued as a source of artistic imagination in the
New World. However, the source of the sublime evolved so drastically that, "It would be tempting to say that had no theory of the sublime existed, Americans would have been forced to invent one."2 The North American landscape contained all characteristics required for the theory of the natural sublime: mountains, deserts, fresh and salt water, extreme seasons of weather and natural disasters. Visitors to great sites such as Niagara Falls, the Grand Canyon, or the Natural Bridge experienced the sublime in an entirely new way: "Its immensity quite took my breath away. Nothing one has read or imagined can wholly prepare the visitor for this herculean span of rock across that abysmal sky."3 The source of this new experience in the sublime was inherently the object itself. Unlike the pervious concept of the sublime that incorporated a personal involvement, the experience of the American sublime inevitably became synonymous with one's physical presence at the site. "The passion cause by the great and sublime in nature, when those causes operate most powerfully, is astonishment; and astonishment is that state of the soul in which all its emotions are suspended, with some degree of horror." $"$ This sense of passion for nature drove the expressions of sublime as heroic achievements of North American landscapes. "As Americans became tourists in their own country, interest in sublime landscapes became not an idle diversion but an act of self-definition." ${ }^{5}$ A general desire emerged to conquer the landscape and share in its importance, thus demonstrating people's ability to conquer their fear and to become part of the sublime object itself. 
As the historian David Nye argues, the American sublime began to develop beyond landscapes and adapted to advancements of industrialization and the continent's geographic expansion. Motivated by development, the experience of the sublime landscape was never intended to preserve the wilderness or halt development; "American sublime transformed the individual's experience of immensity and awe into a belief in national greatness. ${ }^{{ }^{6}}$ It provided the framework for a sense of pride in their natural wonderlands and superiority for their industrial achievements and ultimately as a symbol of historical significance of our manufactured landscapes (while becoming a necessity to preserve portions of sublime landscapes, otherwise known as National Parks). Thomas Jefferson shifted the focus from the wild to the agrarian; his landscapes featured the rural grid of roads and farmlands. "The common man's pleasure in the pastoral... derived not from his comparative proximity to nature but from his recognition that, in agricultural and pastoral settings, nature had been subdued and rendered orderly." Conquering the landscape was extended through human-made marks of attainment. The labour-saving machines of the Industrial Revolution appealed to the North American nation concerned with establishing economic security through civilian independence and the promotion of industry. For this reason, any development in the field of agriculture was well received. The railroad would become the link between Sublime landscapes and Industrial sublime through the alteration of how one experienced and dominated the landscape. The construction of the railroad into agricultural society invigorated national economies and promoted technology as the framework for a new concept of the American sublime. However, the development of the steam train heightened this phenomenon and quickly it turned into a local spectacle.

"On Christmas day of 1830, the citizens of Charleston, South Carolina, were the first people to ride on a steam train in the United States." About 140 people, including politicians, Charleston investors, and military men rode over the 6-mile line, while the general public stood along the tracks and cheered. ${ }^{9}$ Spectators were amazed at the sight of a line of 
carts moving at speeds unmatched by horse and for longer distances. The 'iron horse' apparently to being travelling under its own man-made power was startling. Furthermore, as a passenger to see the landscape from such speed altered the experience of the natural sublime, the world seemed to pass by as the view sat stationary. "After observing American railroads, [a viewer] asked: 'Is there anything which gives a nobler idea of the power of man than the steam engine in the form in which it is applied to produce motion on railroads? It is more than a machine, it is almost a living being." 10 Through the lens of the sublime, Americans equated human-made landscapes equal to natural landscapes.

With the advancements of the industrial revolution, cities across North America were transformed by the application of large-scale manufacturing sites. At first these factories were believed to extend the landscape of the natural world in the same way Jefferson's grid organized the landscape to produce something that was of benefit to the country. Like the development of the railway, scale, speed, and fear are elements of Industrial sublime that showcase the success of man-made dominance. However, fundamentally Industrial Sublime requires the application of technology in production, when the methods of manufacturing rationalized by the desire to achieve an end goal. Industrial Sublime is the product of the machine. Lewis Mumford describes the machine as a specialization of a specific function, and performs only one operation. Moreover, the machines of the Industrial Revolution (such as a Blast Furnace) solely depend on an external source of power, a very specialized kind of adaptive machine. ${ }^{11}$ The distinction between the tool and the machine of the North American factories is the displacement of human participation. Workers transitioned from tradesmen to observers, monitoring the manufacturing process. Machines grew to scales incomprehensible to the human hand. Workers constructed machines that offered the same sense of awe and fear though an overwhelming scale that was present in the natural landscapes of North America. Unless dormant, workers could not control these machines and feared for their safety. 
Coal as the new mechanical power source enabled this tremendous growth of manufacturing sites in North America. Coupled with the seemingly endless production demands of World War I and II, North American cities flourished. ${ }^{12}$ This unprecedented growth led the almost aimless expansion of industrial sites and the dogma of consumerism. "Industry was directed not merely to the multiplication of goods and to an increase in their variety: it was directed toward the multiplication of the desire for goods." 13 Although machines overpowered human control in production, an economy based on acquisition continued to exploit the desire to dominate via human-made landscapes.

Inevitably, the capacity of production in North America surpassed the local demand as companies attempted to shift to compete in the global market. Following the boom of the postwar economy slowly the large-scale North American factories have struggled to adapt to new technology while providing affordable products. Global competition has only risen; consequently, many manufacturing sites have been abandoned. The decline of industry has, however, given rise to an original American Sublime. Now dormant, the factories inspire feelings of the sublime. Although these post industry sites are no longer productive their beauty is in the ruin itself. In its previous life the factory site was not open for public experience; however, its past still lies in the physical manifestation of the machine; a memorial of its lost history. 


\section{The Steel Company of Canada, Limited}

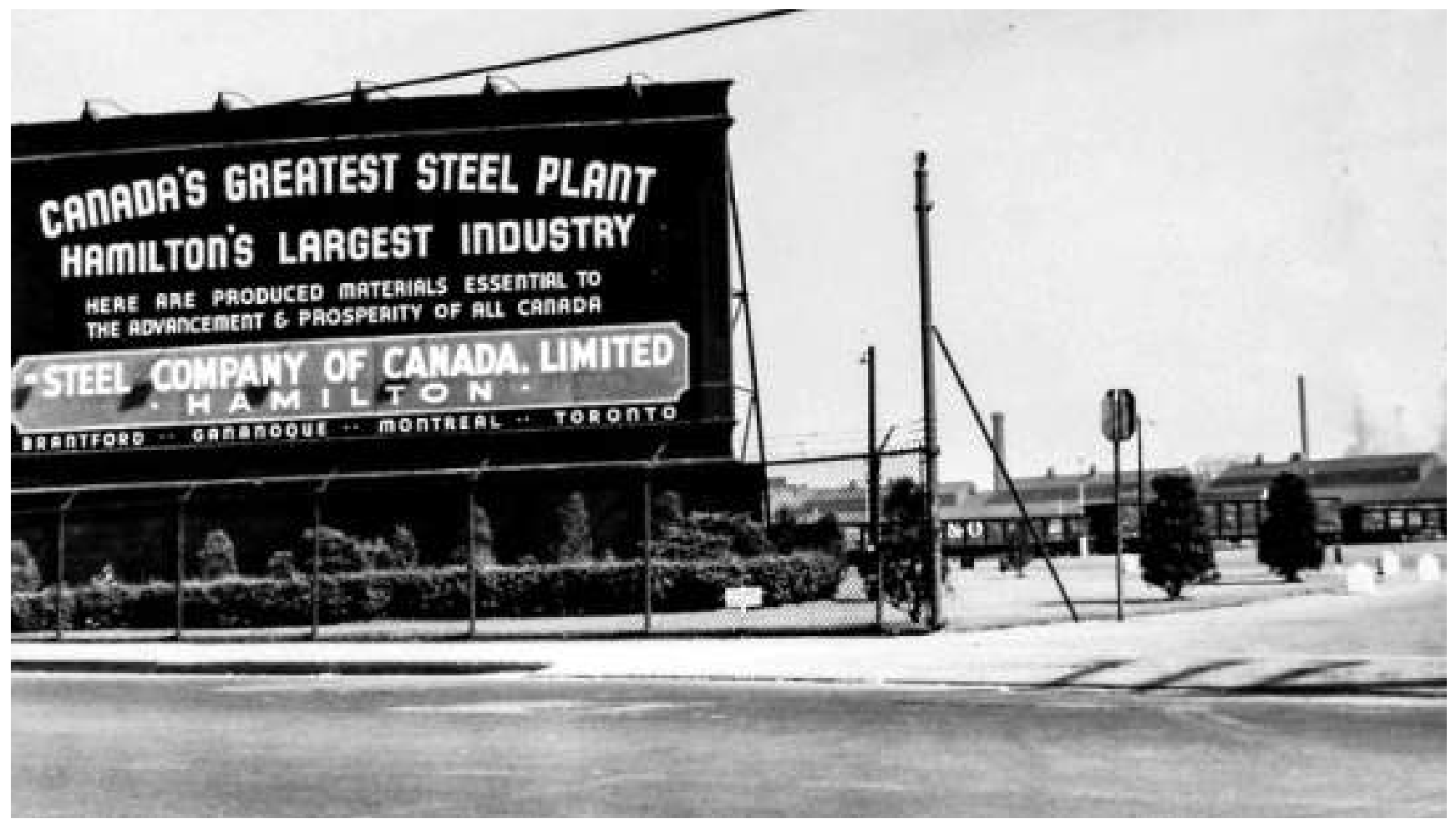




\section{Max Aitken}

Following a short recession in 1907, a flood of industrial amalgamations came to fruition in Canada. Between 1909 and 191141 new corporations formed from 196 individual companies with a total authorized capital of one-third of a billion dollars. ${ }^{14}$ Of these amalgamations Max Aitken, a young man from New Brunswick was responsible for the three largest and most important companies. These included Canadian Car and Foundry (1909), Canada Cement (1910) and Hamilton's Steel Company of Canada, Limited (1910). ${ }^{15}$ With Aitken's purchase of the Montreal Rolling Mills from William McMaster early in 1910, soon after word spread south to United States Steel Corporation and other American steel corporations like Jones and Laughlin, interested US Steel offered to purchase the company before Aitkens made any changes. However, he had no intention of reselling the Montreal Rolling Mills to an American company but wished to build up Canadian industry. 'Aitken's refusal was probably one factor in deciding the United States Steel Corporation to postpone the building of the integrated steel plant for which they had purchased a site near Windsor, Ontario. Instead of investing in a Canadian branch corporation, they opened a sales office in Toronto in 1911."16 With US Steel's change of plans, it seemed less valuable to hang onto Montreal's Dominion Wire Manufacturing Company, the largest Canadian finishing plant. This inevitably left a second Montreal firm interested in Aitken's plan to build a Canadian steel merger. American William Farrell for the Dominion Wire Manufacturing Company was not a direct party to Aitkens proposal, but ready to sell if an agreement was reached. Other companies involved in the negotiations included Cyrus Birge of the Canada Screw Company and Lloyd Harris of the Canada Bolt and Nut Company. Although interest in this merger surmounted, only two companies that counted in the negotiations: Max Aitken of the Montreal Rolling Mills and Charles Wilcox representing the Hamilton Steel and Iron Company. Charles Wilcox would become the first president of the amalgamated Steel Company of Canada, Limited and company voting control would rest with the workers of the Hamilton Company. ${ }^{17}$ "They were the men who brought the key primary iron and steel plant into the merger, and upon their future initiative and good management the success of the new company would depend heavily."18 


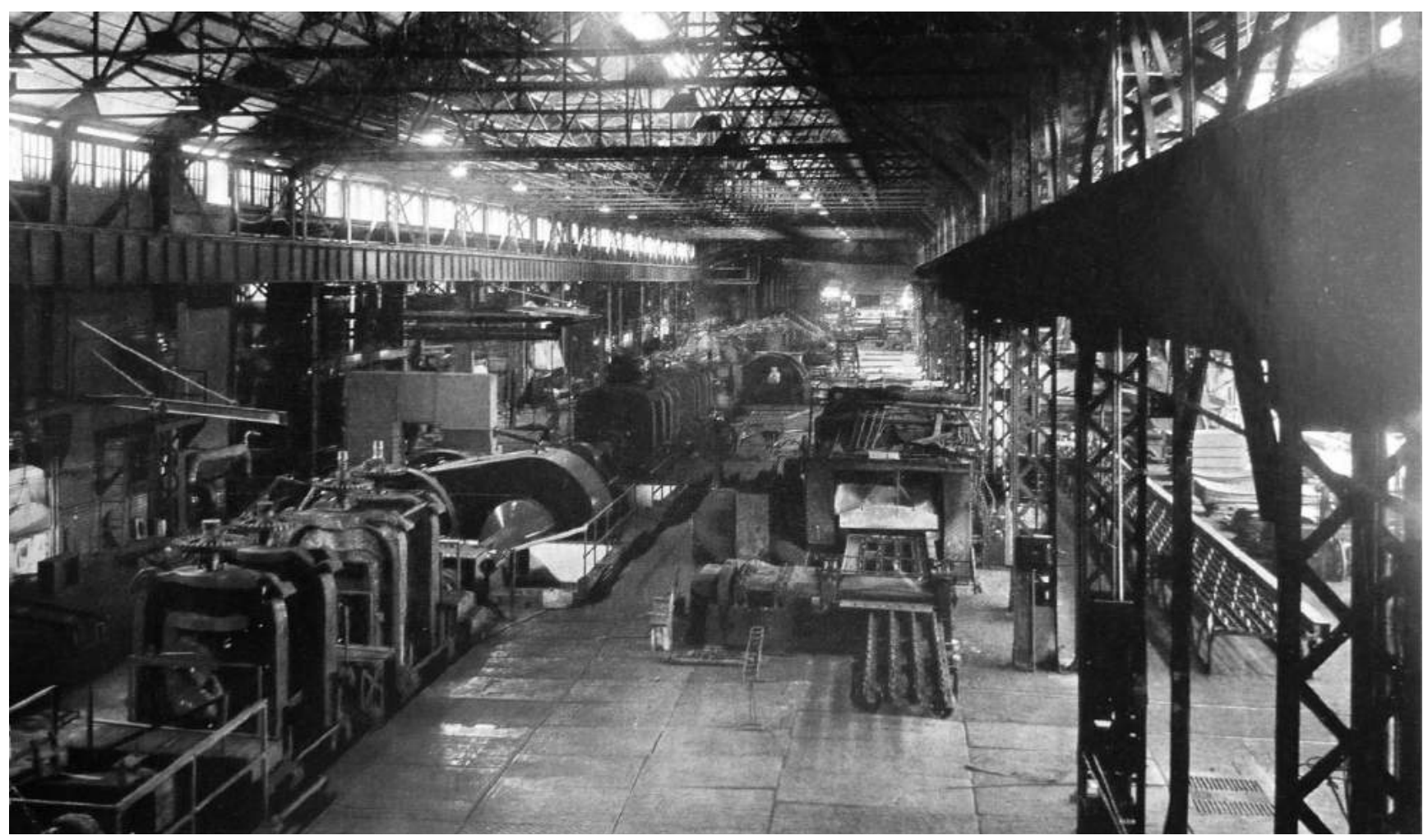

SHEET MILL 1932

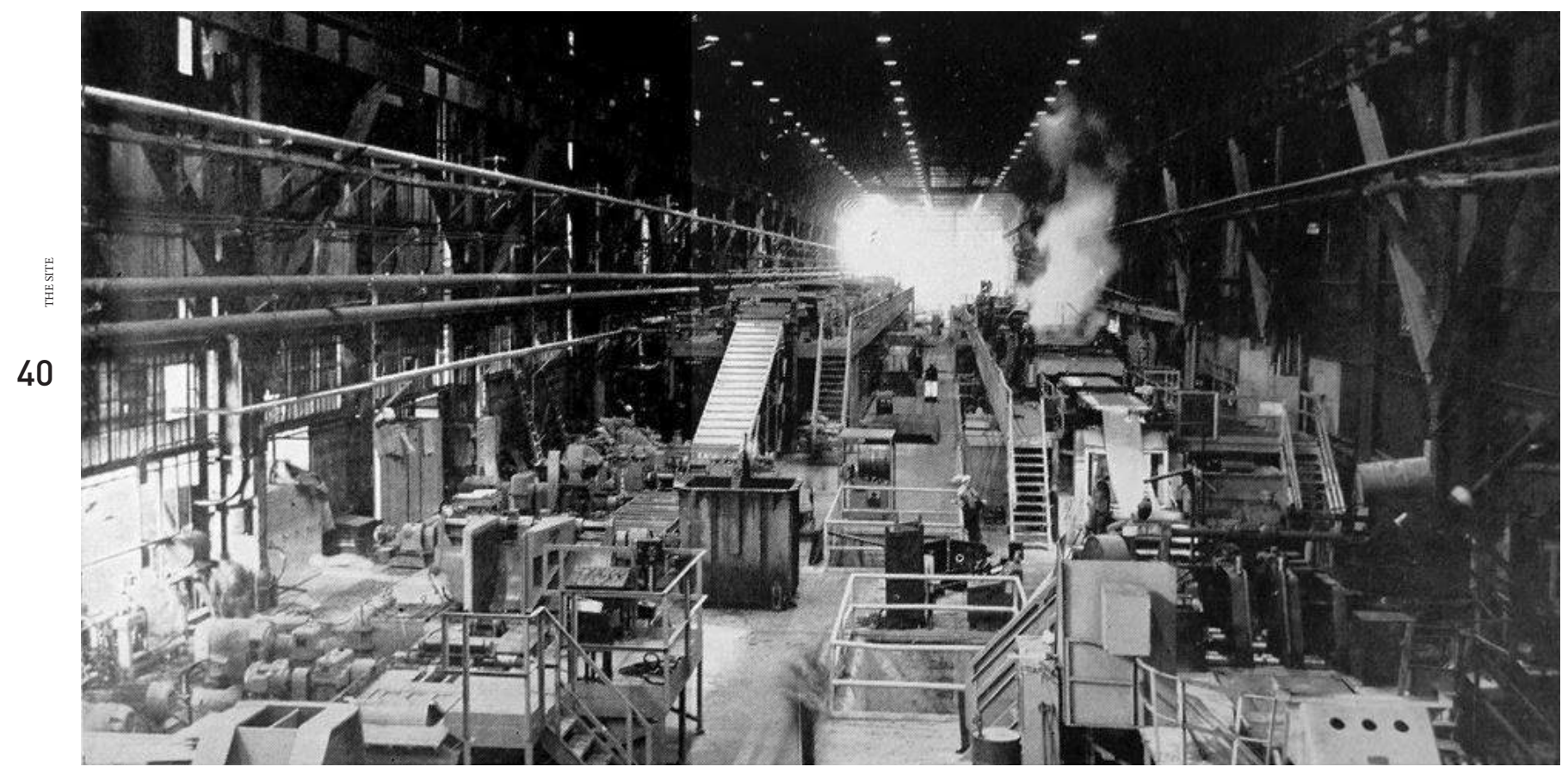

No. 2 CONTINUOUS PICKLE LINE 


\section{Company Birth}

The Steel Company of Canada, Limited was created on June $8^{\text {th }}, 1910$. The new company was formed from five separate companies, Montreal Rolling Mills, Hamilton Steel and Iron Company, Canada Bolt and Nut Company, Canada Screw Company, and Dominion Wire Manufacturing Company. The name of the new company was originally 'Canadian Steel Corporation, Limited'. Not unlike many of the new mergers of this era, companies began with the word 'Canada' or 'Canadian'; it was a time of growing patriotism and a need for a dominant position within the North American industrial field. "There was a conveniently obvious parallel, also, to the name and example of the United States Steel Corporation." ${ }^{19}$ Ultimately, to avoid confusion with another Canadian steel company, the company's name was altered and ultimately legally changed to the company's nickname, Stelco in 1980.

\section{Recession}

The decades following the birth of Stelco were trying times filled with bursts of extreme progress and moments that threatened the company's very existence. The new company was initially faced with intense American competition, to meet this and capture a large portion of the Canadian market, Stelco set out with a large building programme for its' future. In addition to reorganizing and modernizing the existing plant, the company added an electrical blooming mill and an electrical combination rod and bar mill, both were the first of its kind installed in North America. Shortly after the expansion in 1913, recession struck the North American economy this timed proved to be particularly severe for heavy industry. The company's trouble during the recession was evident in the lives of its employees. "Stelco's total employment, which had built up to 6200 from 5100 at the time of the merger, was now cut drastically to $4400 .{ }^{.20}$

\section{World War One}

The First World War demanded two resources from Canada: artillery shells and soldiers. ${ }^{21}$ The war brought a general revival to the company through its steel bar exports used in British artillery shells and other raw material for national munitions manufacturing. This also returned Canadian demand for regular steel products, similar to the pre-1913 economy. However, with its new production capacity from the expansion programme, the company saw total profits of 1915 higher than ever before. ${ }^{22}$ Over the next 3 years Stelco was able to push forward with its vision as a fully integrated steel-making enterprise. This included new open hearths, finishing upgrades, 


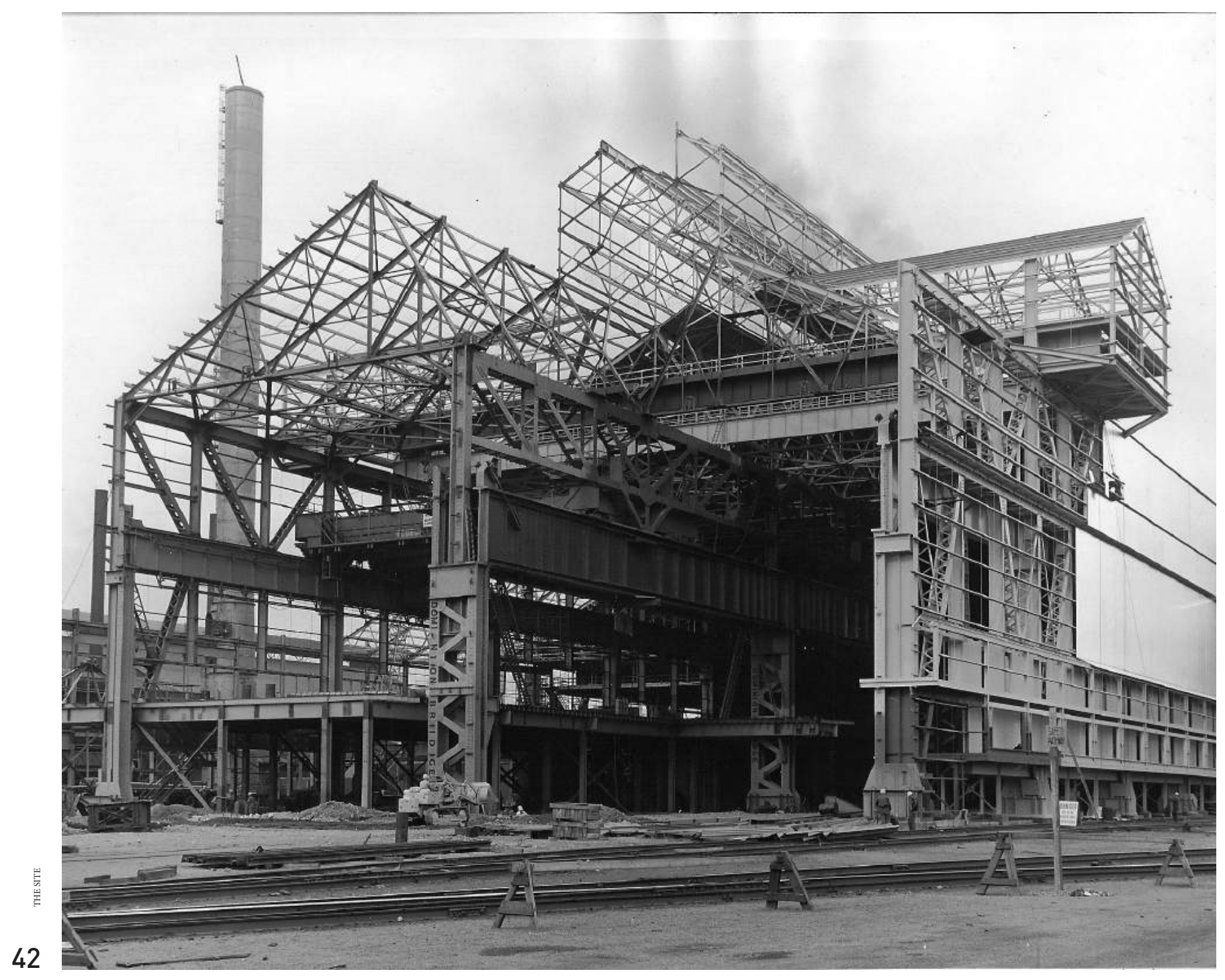

NEW BLAST FURNACE 1951 
construction of a sheet mill, by-product coke oven and purchase of the American coal mines. Although these changes were only possible during the profitable years, the company was learning to remain sustainable for the unpredictable times. With the great depression approaching, Stelco had priorities in its employees, although wage increases were nearly impossible, their employees had pensions, benefits, shorter 5-day workweeks and an advanced safety program. The company made changes wherever possible to save labour and simplify plant layout thus saving valuable money. Many of these changes are still evident in the structure of the factory today; electric overhead cranes scale up and down the building replace much of the steam and manpower.

\section{Growth and Expansion}

Stelco's growth and technological advancements during the 20s, catapulted the company to the largest producer of steel in Canada. ${ }^{23}$

\section{Great Depression}

The company's global standing sustained it through the less profitable years; in addition the company's location became a great advantage. ${ }^{24}$ The Steel Company of Canada (together with its smaller Hamilton rival, Dominion Foundries and Steel) was ideally located to benefit from the trend of new industries concentrated in the industrial belt along the lower Great Lakes. "Stelco's plants were within a few miles, in some cases within a few hundred yards, of the great majority of their steel-using customers." ${ }^{25}$ The benefits of its location were evident during the Great Depression in the 1930s.

\section{World War Two}

Stelco played a significant role in the production of steel used in shipbuilding during the Second World War. ${ }^{26}$ Canadian ships were essential to keep supplies moving across the North Atlantic, with naval escorts against enemy submarines. "By midsummer of 1942 about forty percent of the escort work in the North Atlantic was being done by the Canadian ships," these efforts were vital to Britain's survival. ${ }^{27}$ "In the seven years of war Canada produced just short of ten billion dollars' worth of munitions and war equipment", including 800000 trucks, 50000 tanks, 16000 aircraft and 23000 railway cars. $^{28}$

\section{Home Front Growth}

This time the war, became personal for Canadians, it demanded mobilization of everything and everyone. Due to the demand of production and lack of trained workforce during World War II, Stelco began to higher women to fulfill the roles their husbands left to join the front line. 


\section{Unionized}

With the success and growth of Canadian heavy industry during the war, a looming prediction of a depression similar to the one following the First World War would ignite a union drive for industrial workers. In February 1945 Stelco, by law recognized Local 1005 of the United Steelworkers of America. ${ }^{29}$ Of the three primary Canadian steel companies, Stelco was the largest and the least unionized following the war. The company paid little attention to union Local 1005; they saw no need to pay more attention to the union than was legally necessary. Stelco's leadership and employee priority saw Hamiltonians through some of the most difficult years in the industry, this in turn made the majority of workers indifferent to the union. Local 1005 decided to force the issue, and compel workers to join through a list of enticing demands. These included "a pay increase of 19 1/2 [cents] an hour, ... a forty-hour week, two weeks' paid vacation after five years' service, a union shop, and the automatic check-off of duties." 30 Although, many of Local 1005 demands were common to those made in other large industries of the time union leaders succeeded in gaining popularity amongst Stelco employees. A strike of an immense scale was inevitable, Stelco as the largest Canadian primary steel plant was at the forefront of the union movement.

\section{Strike}

The Local 1005 strike began on the Monday morning of July 15 ${ }^{\text {th }}, 1946$ with some three thousand employees behind them. It would not end until October 4th, a total of 81 days. ${ }^{31}$ Picketers surrounded the all-possible entrances to the plant, cutting off all road and rail connections with their tents, canteens, and parades. Employees, refusing to strike, Scabs were held up in the factory and supplied with food, laundry, personal supplies and leisure activities via the Burlington bay. ${ }^{32}$ Eventually through government encouragement, Stelco was pressed to accept a union wage increase of

$4413^{1 / 2}$ cents an hour and settle union security. ${ }^{33}$ Through this first strike Local 1005 established themselves has hard but fair bargainers, which showed its true value for a future ridden with employer/employee conflict. ${ }^{34}$ While Stelco saw its first 35 years with little employee conflict however, its future would be ridden with layoffs and Local 1005 strikes. Although each conflict never reach the same intensity as the first strike in 1946, "over one-tenth of the population of Hamilton was made up of families and dependents of Stelco wage earners, and there were many other men whose jobs were closely related to Stelco's activities." ${ }^{35}$ Consequently, every company lay-off or strike was deeply felt in the lives of Hamilton residents. 


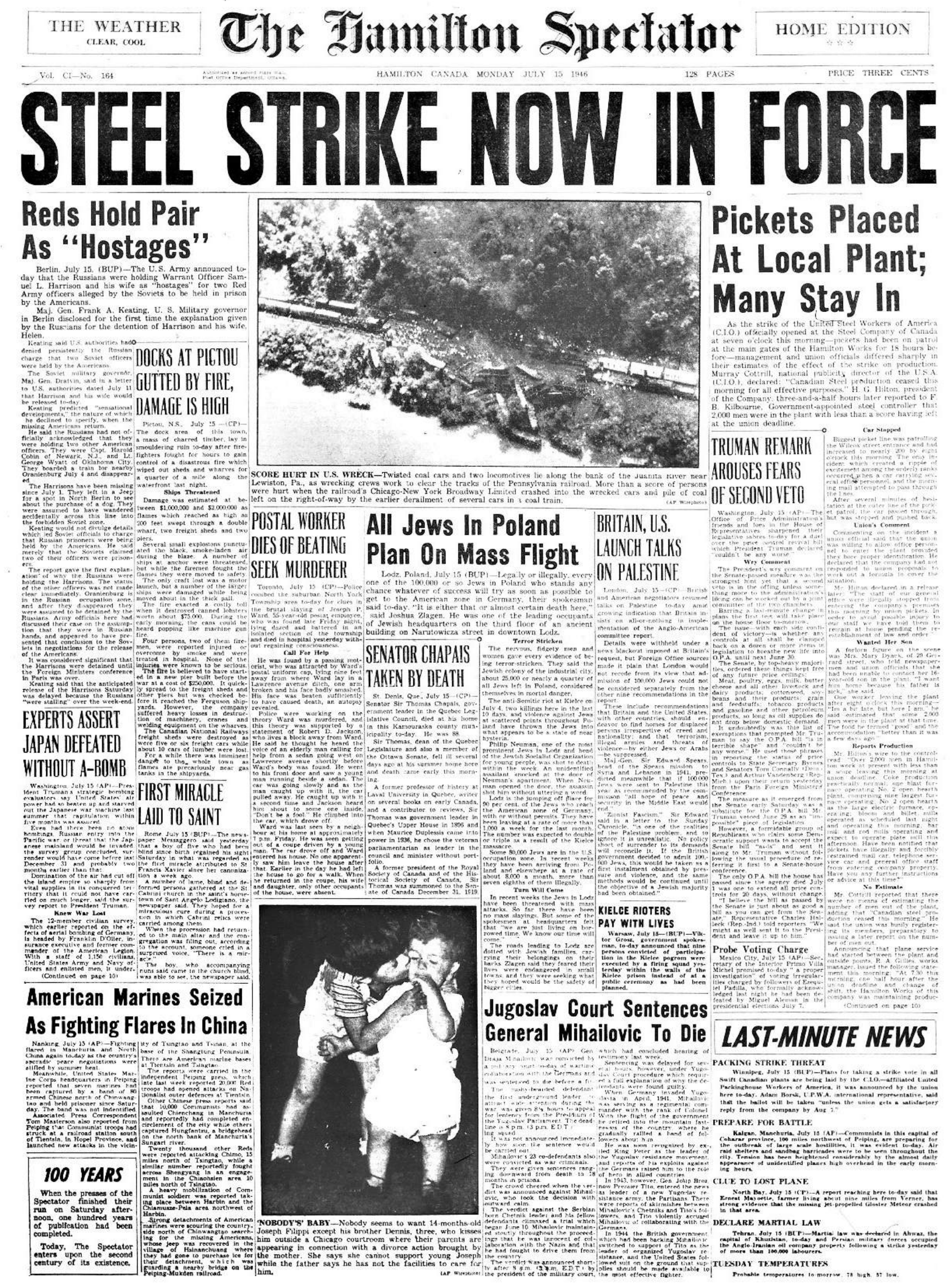




\section{Expansion and Modernization}

"Stelco's expansion and modernization programme during the nineteen-fifties cost one quarter of a billion dollars. It was well over twice the amount spent in the forty years of the company's history between 1910 and 1949." "36 Stelco continued to be the biggest steelmaking company in Canada with an annual capacity of about two million ingot tons. ${ }^{37}$

\section{Strike}

\section{Strike}

\section{Steel Consumption}

The world steel consumption increased from 200 million to 600 million tons per year from 1954, following the war to $1974 .^{38}$ This steady growth was forecasted to continue for the next 20 years. Based on this economic prediction, the company began to plan the construction of the new Lake Erie Works.

\section{STELCO Inc.}

Shortly before opening the new plant, the company's common nickname, Stelco was formerly adopted as the legal name. This rebranding publically marked its strength and significance as a fundamental Canadian company within the steel industry 70 years after its inauguration.

\section{Stelco: Lake Erie Works}

The new Lake Erie Works plant, completed on June $1^{\text {st }} 1980$, was designed to produce 10 million tons of steel annually and fulfill the forecast of future domestic demand. ${ }^{39}$ The plant is located in Nanticoke, Ontario along the Welland Canal. Like the Hamilton location,

46 the new Lake Erie plant was a source of employment for surrounding businesses and residents of the Haldimand and Norfolk counties. The plant took 6 years to construct, 15 years of planning and cost Stelco $\$ 870$ million. At the time it was called 'one of the most advanced and productive steel-manufacturing facilities in the world. ${ }^{30}$ Unfortunately, the plant would suffer the same future ridden with strikes, lockouts and shutdowns.

\section{Strike}




\section{Recession}

Following the opening of the Lake Erie location, the world-steel industry was stagnant from 1974 to 2001. "In recent years, with China going from an agrarian economy to an industrialized one, once again this change has given a steep rise in steel demand. China, however, has increased its steel-making capacity and thus has little need for massive steel imports. Meanwhile, Canada's domestic consumption remains flat at about 15 million metric tons, roughly where it was in 1972." ${ }^{\prime 1}$ This error in the steel industry's consumption forecast was palpable during a recession that hit only 2 years after Stelco's largest expansion.

\section{Strike}

\section{Environment Protection}

Stelco's first steps towards ending air pollution in Hamilton were in 1960 with the installation of new filtration equipment on the open hearth and the financing of apollution test study done by the Ontario Research Council. Since these initial actions, the company supported a three-stage effort in 1992 to get Hamilton Harbour off the list of 43 Environmental Areas of Concern on the Great Lakes by $2015 .{ }^{42}$

\section{Competition Grows Stronger}

The local competition, "Dofasco kept up to Stelco in their production of sheet steel. Dofasco's ability to make small batches of the commoner grades of steel in a matter of minutes by the oxygen process also gave them an advantage in fitting custom orders into their schedule quickly." 43 The same innovation that marked Stelco's earlier years faded and Dofasco quickly filled any gaps that Stelco could no longer fulfill in a smaller market. In 1993 Dofasco surpassed Stelco annual profits and nearly 2 decades later Dofasco saw quarterly profits unmatched in its 100-year history.

\section{Bankruptcy Protection}

With extreme financial difficulties, Stelco went under court ordered CCAA protection from its creditors in July of 2004 and exited on March 31 $1^{\text {st }}$ 2006. The Companies' Creditors Arrangement Act (commonly referred to as the CCAA) is a federal government act that provides creditor protection for insolvent (or inevitable insolvent such as Stelco) corporations with financial responsibilities of $\$ 5$ million or more. This allows corporations to restructure their financial affairs, avoid bankruptcy and provide some payment for creditors. ${ }^{44}$ 


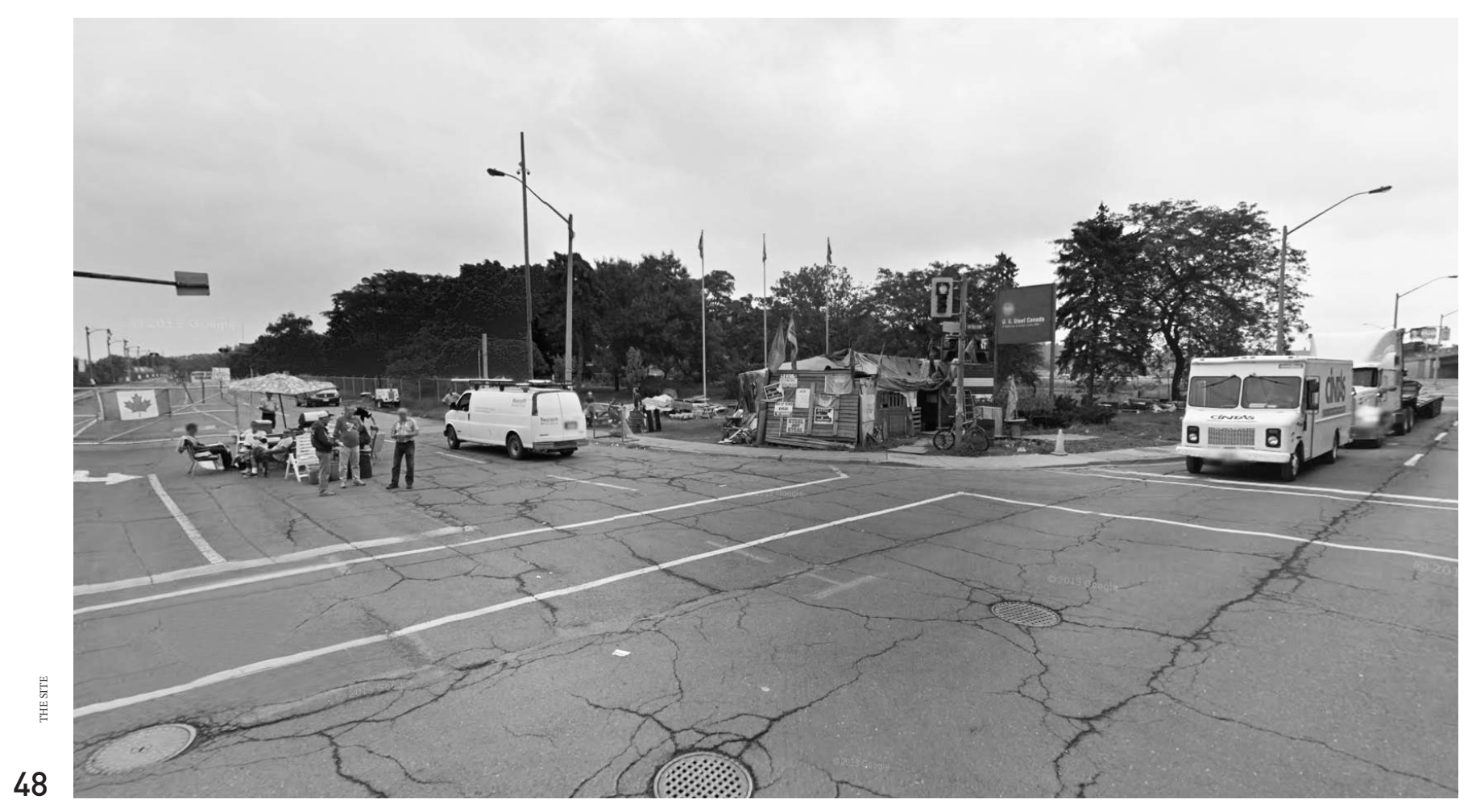

STELCO EMPLOYEE LOCKOUT 2011 


\section{Ends Protection}

Stelco's Plan of Arrangement restructured the remaining operations into 9 separate businesses operated by the corporate entity of Stelco. The company emerged from bankruptcy protection with Rodney Mott as it new CEO, notorious for his history in the U.S. Steel turnaround and the looming guilt of the $\$ 150$ million funding from the Ontario government for pension shortfalls. ${ }^{45}$

\section{SOLD! U.S. Steel Canada Inc.}

Unfortunately, Mott's efforts to cut costs through staffing numbers, buyouts and attrition did not yield the same results as it did in the past with U.S. Steel. The steelmaker lost $\$ 240$ million in the first four quarters since emerging from bankruptcy. By the summer of 2007, Motts announced plans to explore a sale. Suitors began touring with a general sense of optimism, fuelled by the company's current profitable quarter of $\$ 5$ million. ${ }^{46}$ Ultimately the very same company Motts saved previously purchase Stelco Inc. for $\$ 1.9$ billion in cash and assumed all debts on August 27, 2007. ${ }^{47}$ And with the sale, the Stelco name was eliminated. The Hamilton operation was renamed to U.S. Steel Canada, Hilton works and Lake Erie works for the Hamilton and Nanticoke locations, respectively. This Canadian fall, sharpened the wound for employees and Hamilton residents as their neighbour and rival, Dofasco experienced a similar sale in the previous year. ArcelorMittal purchased Dofasco in 2006, the company is now a standalone subsidiary. Although the steelmaker was integrated into their international operations, ArcelorMittal retained the Dofasco name.

\section{Employee Lay Off}

Employees take another hard hit following the American sale when U.S Steel lays off more than 700 Hamilton workers due to the global economic meltdown and its affects on the steel industry. ${ }^{48}$

\section{Shutdown}

U.S. Steel shuts down the majority of its Canadian operations. Production in Hamilton is stopped completely after the furnace is shutdown due to a decreasing demand in steel.

\section{Employees Lock Out}

With the continued shut down the company locks out approximately 900 workers demanding changes to employee pensions, during the company's $100^{\text {th }}$ anniversary year. Although this dispute was company initiated it escalated to emotions and actions similar to the first Local 1005 Strike of 1946. Picketers lined the streets surrounding the site and with government support the issue became personal for Canadians. During this period, the federal government takes the company to court seeking fines of $\$ 10000$ a day for broken employment and production promises. ${ }^{49}$ 


\section{Lock Out Ends}

Almost a year later the lock out ends with a new contract between U.S. Steel and Local 1005, however only 650 employees of the 900 return to work. The company did not restart its blast furnace or steel production. Months later, the government drops its law suit against U.S. Steel and in return the company agrees to invest a minimum of $\$ 50$ million in its two Canadian locations by December 2015 and financial contributions toward local community and education programs of $\$ 3$ million. ${ }^{50}$

\section{Idle Steel Making}

Steel production begins again at the Hamilton location, however the company claims the post-recession market is still too low to restart the blast furnace.

\section{Shutdown}

Published in the Hamilton Spectator, Stelco made the announcement that shocked the city; the "United States Steel Corp. will permanently cease steel production at its Hamilton mill at the end of the year, ending an era that goes back more than a century." ${ }^{\prime 1}$ After a brief period of sluggish production, iron and steelmaking at the Hamilton location were shutdown; coke production continued to support the Lake Erie Works location.

\section{Bankruptcy Protection... Again}

In the summer of 2014 U.S. Steel Canada employed a total of 2337 individuals between both the Lake Erie and Hilton Works locations, a devastating decline from the 6200 Hamilton employees a century before. ${ }^{52}$ Although the company no longer employs $10 \%$ of the city's population a large portion of their debt is due in part to the extensive list of retired pensioners. The company's current employee breakdown: Corporate 169, Hamilton 771, and Nanticoke, 1397. A total of 2337 employees. 'U.S Steel [Canada] applies for bankruptcy protection from creditors, and pensioners are in jeopardy of loosing $30 \%$ of their pensions plus benefits if the company goes under." ${ }^{93}$ Despite the hopeful future following the previous bankruptcy protection and the American sale, the company failed to get the struggling company back on its feet.

\section{Partial Sale}

In mid-December U.S. Steel Canada started seeking offers of sale for portions of its surplus land on the Hamilton site. The sale would contribute to the restructuring process the company is currently undergoing. Although the company has said in the past they would not sell land to competitors and are ideally looking for offers from the City, any potential offers are not public domain at this time. 
“United States Steel Corp. will permanently cease steel production at its Hamilton mill at the end of the year, ending an era that goes back more than a century."

\section{HAMILTON SPECTATOR 2013}


1 Edmund Burke, On the Sublime and Beautiful (New York: P.F. Collier \& Son, 1909-14), Vol. XXIV, Part I, Section VII.

2 David E. Nye, American Technological Sublime (London: MIT Press, 1994), 1.

3 Ibid, 26.

4 Burke, On the Sublime and Beautiful, Part 2, Section I.

5 Nye, American Technological Sublime, 24.

6 Ibid, 43.

7 Ibid, 37.

8 Ibid, 52.

9 Ibid.

10 Ibid, 54.

11 Lewis Mumford, Technics and Civilization (New York: Harcourt,

Brace \& World, Inc.: 1963), 11.

12 Ibid, 156.

13 Ibid, 391.

14 William Kilborn, 24 The Elements Combined, A History of The Steel Company of Canada (Toronto, Vancouver: Clarke, Irwin \&

Company Limited, 1960), 66.

15 “Stelco Inc," Historica Canada, accessed March 26, 2015, http:// www.thecanadianencyclopedia.ca/en/article/stelco-inc/.

16 Kilborn, 24 Elements Combined, 70.

17 “Stelco Inc. History," Funding Universe, accessed March 26, 2015,

http://www.fundinguniverse.com/company-histories/stelco-inc-history/.

18 Kilborn, 24 Elements Combined, 73.

52

19 Ibid, 76

20 Ibid, 95

21 "Stelco Inc. History."

22 Kilborn, 24 Elements Combined, 102.

23 "Stelco Inc."

24 Ibid.

25 Kilborn, 24 Elements Combined, 127.

26 "Stelco Inc. History."

27 Kilborn, 24 Elements Combined, 161. 


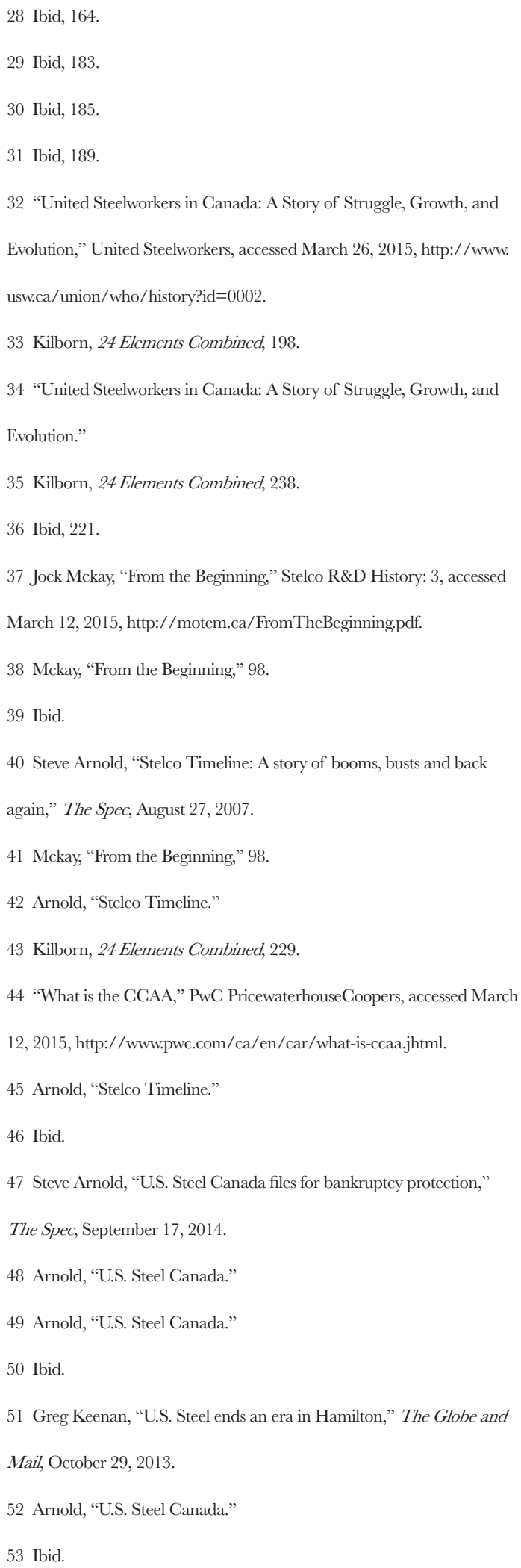




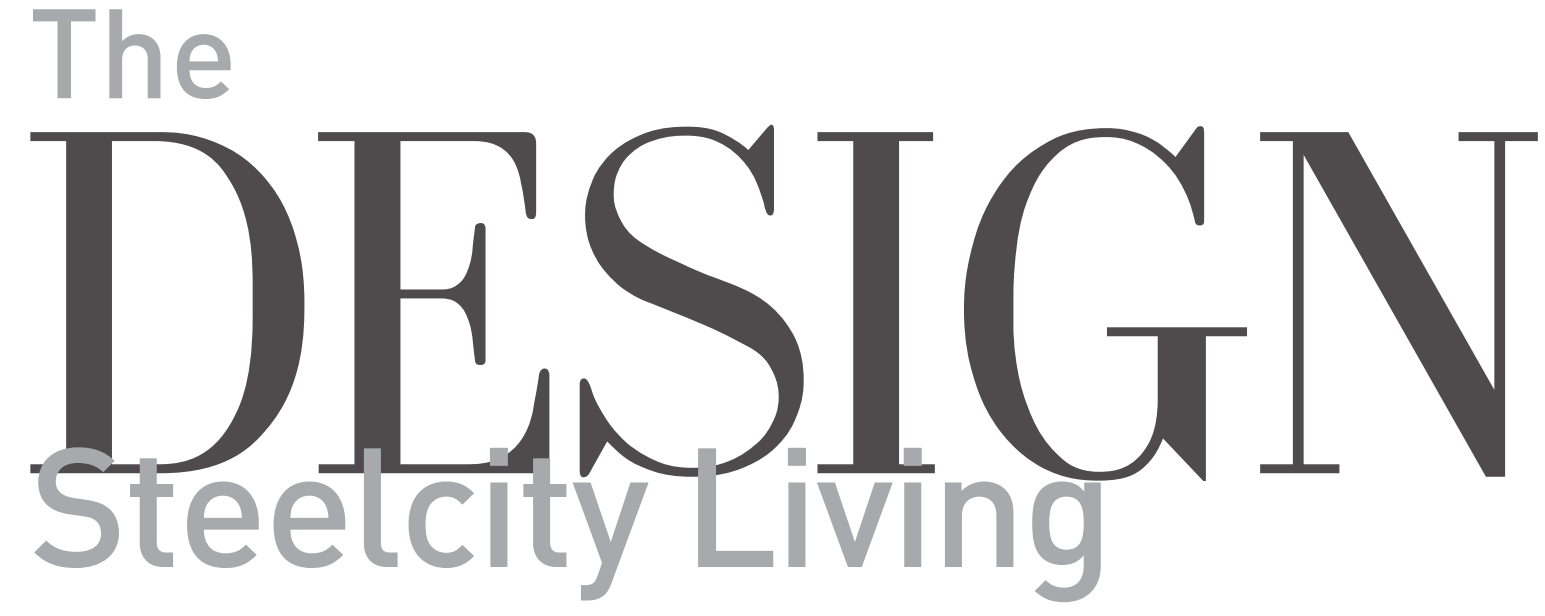

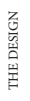

54 


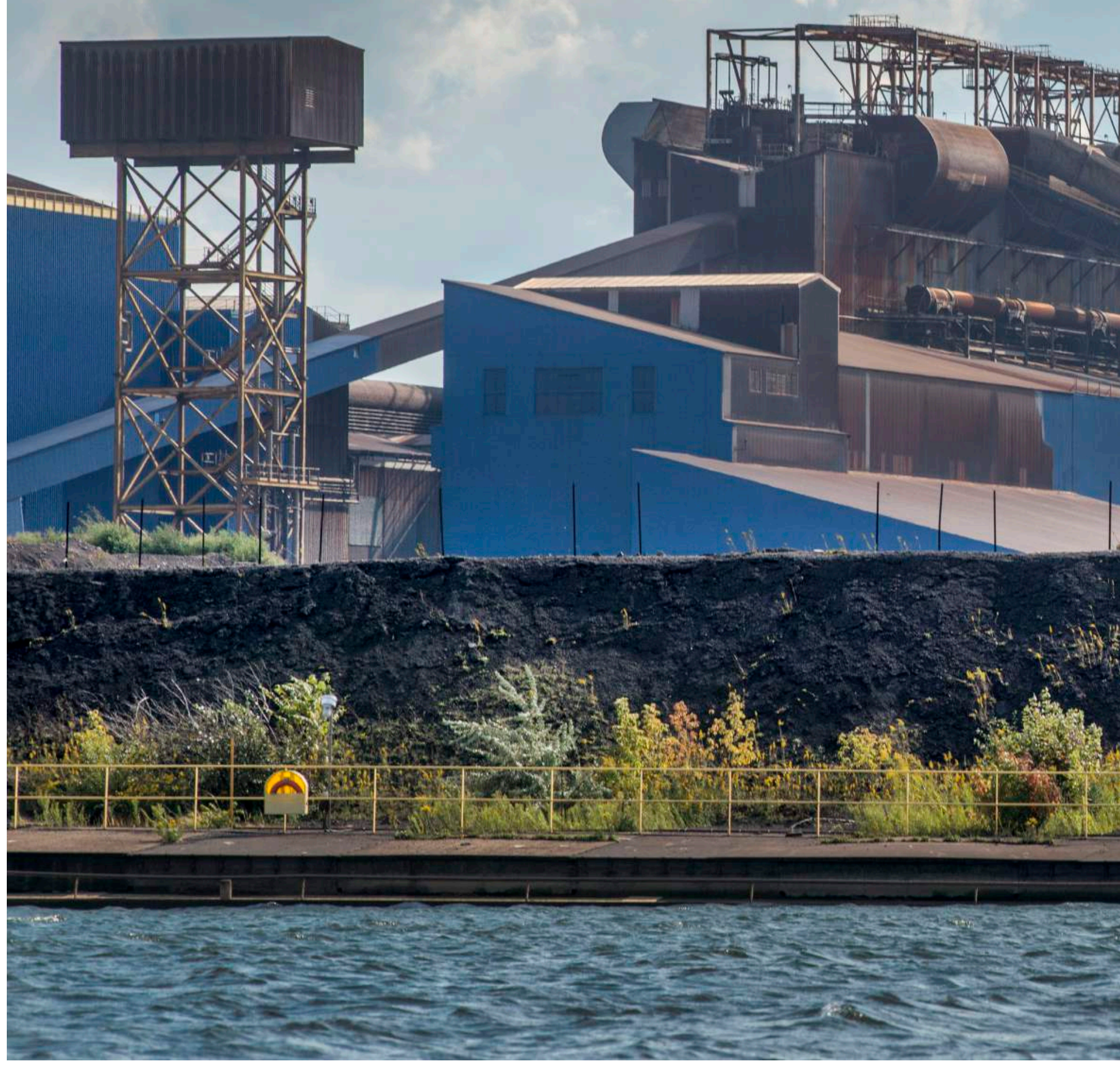




\section{Post-Industrial Sites}

The industrial age transformed the physical landscapes of urban cities. These industrialized landscapes are a result of mass production of heavy industry and the growth of public consumption. The outsourcing of heavy industry turned the North American market into a global competition with less developed countries manufacturing the same products at a lower cost. The outcome is deindustrialization: the economic and physical struggle to recover as a post-industrial city. Although these brownfield sites represent a financially prosperous age in western manufacturing, the environmental side effects of its existence will continue to impair the future development of a brownfield site for programs beyond heavy industry. For this reason, many of these sites remain vacant. However, abandoned brownfield sites are fundamentally unproductive and, therefore, of no value to the recovery of a post-industrial city.

The U.S. Steel Canada factory in Hamilton provides a unique setting for development, unlike any other brownfield redevelopment in Ontario. Its urban location, waterfront access and sheer scale have the opportunity to catapult Hamilton into a prolonged period of urban renewal, thus making it a prototype for similar rust belt cities. This project, Steelcity Living provides a method and solution for Hamilton's and other brownfield developments in North America. It seeks to reoccupy the site from private industry and transforms it for public habitation through the layering of mixed-use programs that provide new opportunities to live, work and play. 


\section{Stelco as Industrial Ruins}

The task to develop a future out of human destruction should not be a method of re-creation or merely preservation. The singular approach to safeguard the factory as industrial ruins or the complete demolition of all existing structures disproves the qualities that the site currently retains and only devastates the site for a second time. The application of a new vision through landscape, architecture and program should be one of adaptation informed by the characteristics of the site. The old industrial substance becomes the basis of the new design. ${ }^{1}$

The remaining industrial fragments at the U.S. Steel Canada plant transitions across the site from machines to architecture, a physical form almost familiar to the urban environment. This transition of the physical characteristics parallels the flow of steel manufacturing from raw materials to product shipment. The west side deals with the arrival and conversion of raw materials, modifying coal to coke in massive ovens. The blast furnaces are central and, they combine the raw materials together, sometimes with scrap metal, to produce steel.

Buildings on the opposite side housed the finishing mills that coated the steel with a protective seal and finally the warehouses that stored the final product before distribution. As production continues across the east end of the plant boasts a distinct shed typology, comparable in size to the site's landmass. These steel shells share a similar cross section, with a flat or pitched roof however, their lengths changed depending on the length of the assembly line. The longest shed at Stelco is approximately 0.75 kilometers long and 21 meters tall (7 storeys). Preserving the wonder in the scale and form of the existing buildings serves as a guiding design principle in the transformation of the Stelco plant for public occupation. 


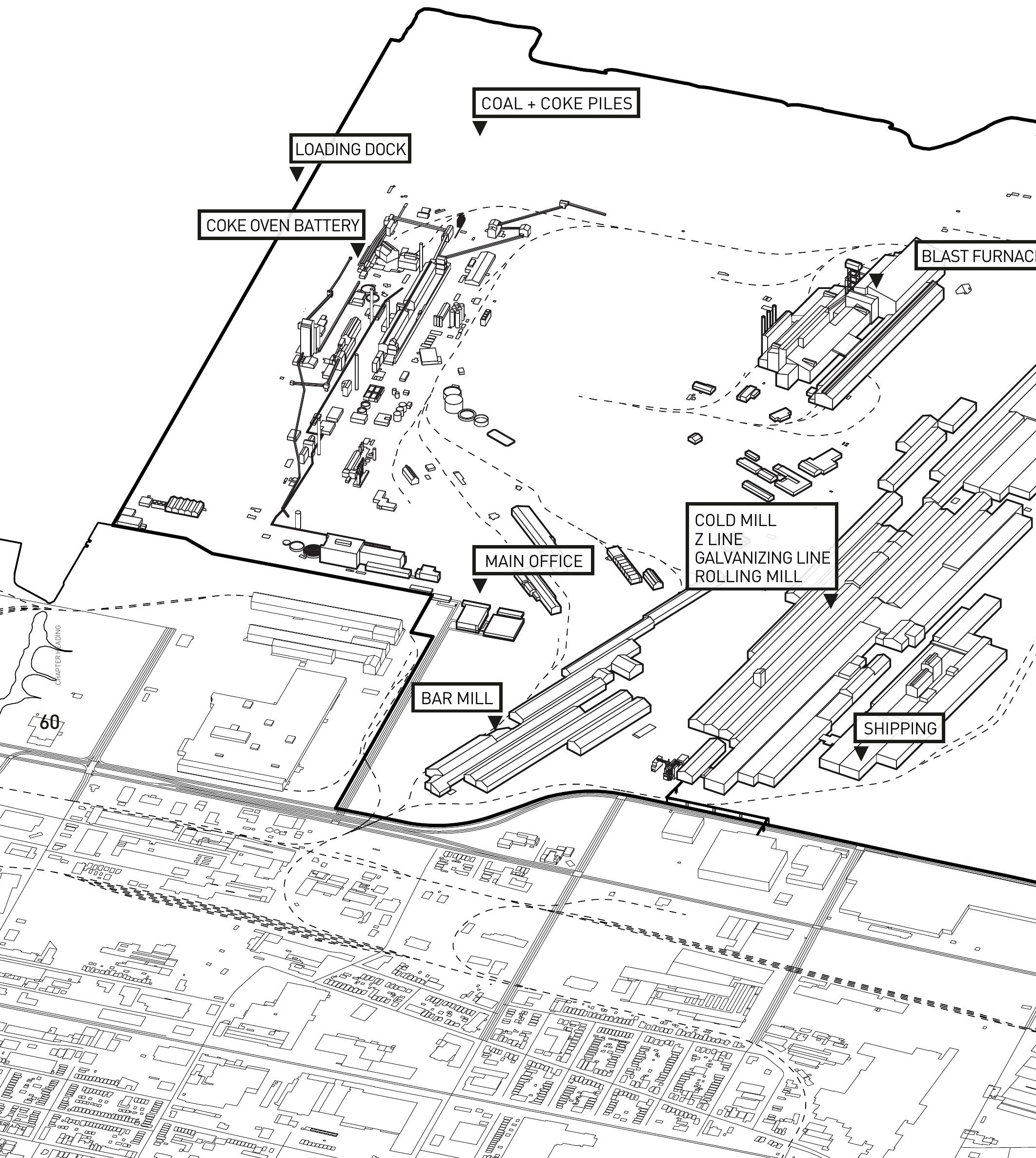




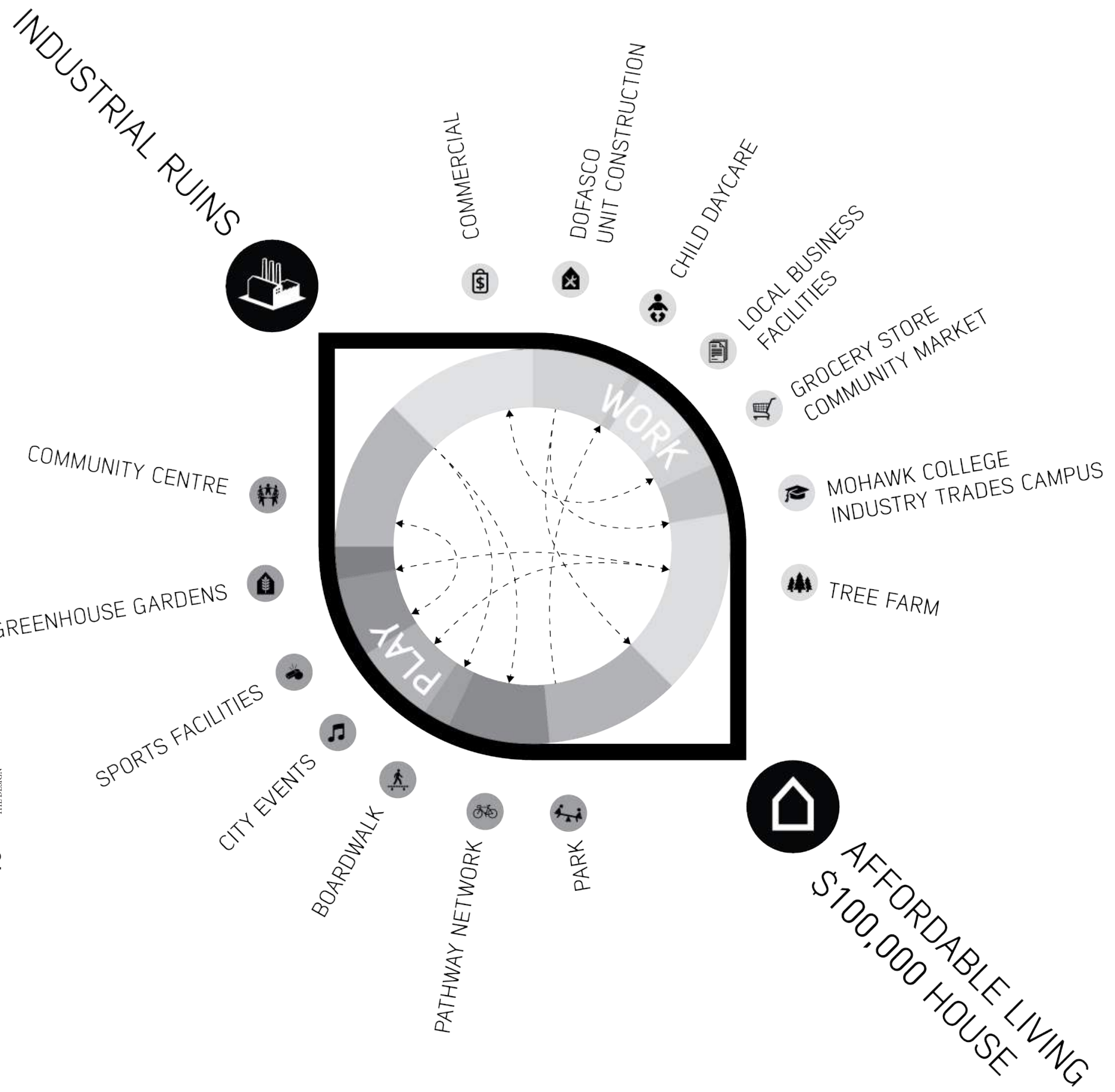




\section{Live, Work and Play}

The adaptation of Stelco is centred on the programmatic relationships between live, work and play. This approach is in accordance with Hamilton's first method to guide new development as outlined in the Urban Hamilton Official Plan adopted in 2009. Through the implication of mix use programming the project, Steelcity Living will provide adequate home ownership for low-income families.

Steelcity Living focuses on the development of landscape as the source of brownfield remediation and the design of affordable housing rooted in the post-industrial ruins. For Hamilton, these are two areas that have been addressed the least in its recent history of urban renewal. 


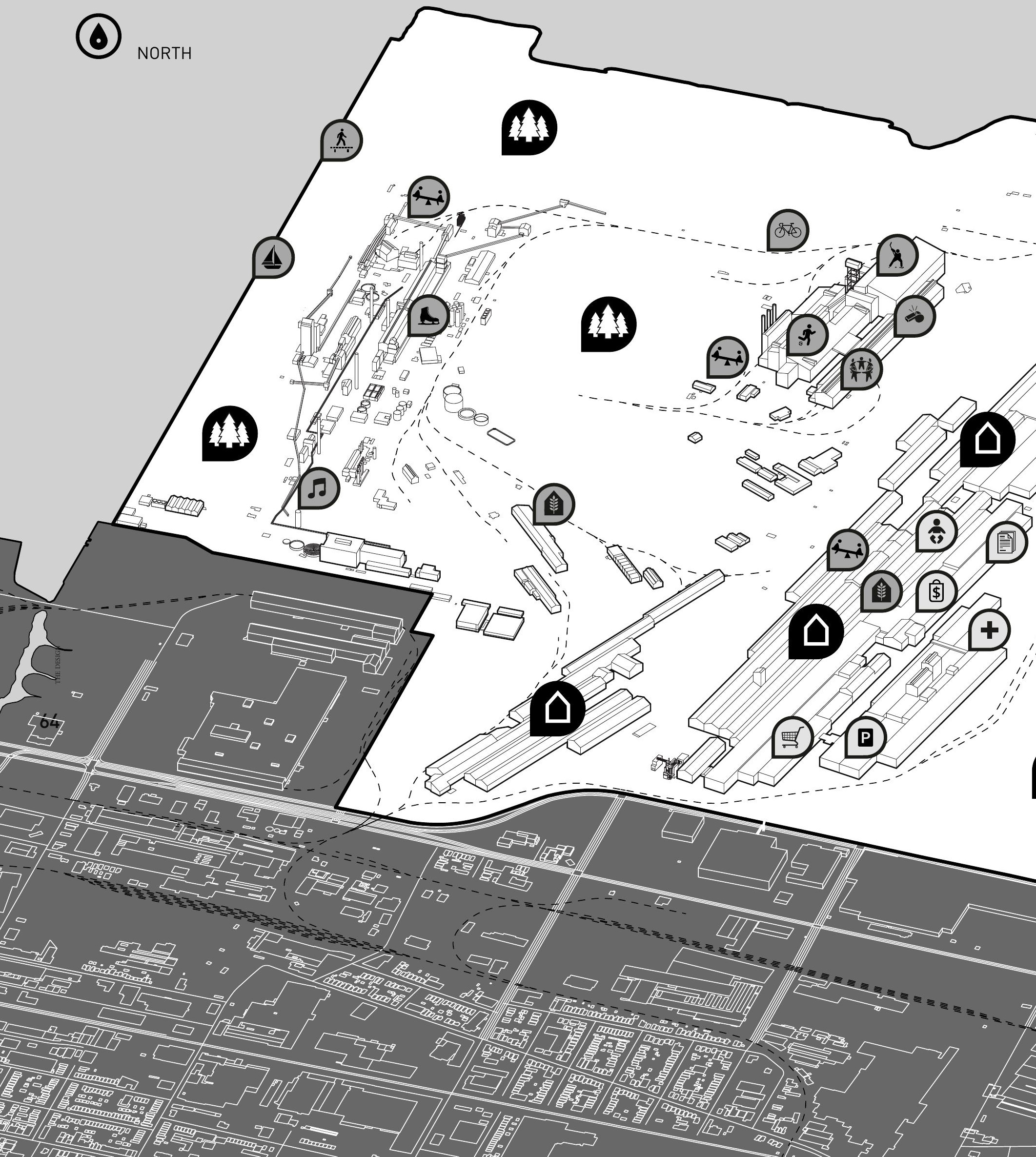




\section{Hamilton's Directions to Guide Development}

In 2009, Hamilton's Official Plan outlined nine direction to guide future development.

Steelcity Living aims to fulfill these guidelines, though some are more applicable than others for a post-industrial site. Specifically, the beginnings of the project are in agreement with the city's intention to develop vacant, maximize the use of existing buildings and respect the unique character of existing buildings. The adaptation of Stelco directly corresponds to the city's first guide for development, a compatible mix of program to provide opportunities to live, work and play. Although Hamilton has begun to outline a successful guide of urban development, it does not provide the necessary framework for development to occur. For example, the complexity, financial expense and lack of precedence to remediate brownfields coupled with the relaxed enforcement of urban boundary expansion enables the continuation of abandoned spaces in rust belt cities, exemplified by the recent Airport Employment Growth District. "Expanding the city's boundaries by the airport was a necessity, even with the brownfield sites in the lower city, says Neil Everson, Hamilton's director of economic development. ${ }^{3}$ In reality, cost is a big factor for prospective buyers: "the city estimates that developing a brownfield site is between 14 and 27 per cent more expensive than a comparable greenfield site." Hamilton offers grants and funding to encourage the sale of brownfield sites, but the city does not to cover the cost of remediation. ${ }^{4}$ As with the airport expansion, the city does not have a great track record for making brownfield sites viable for future use. Hamilton understands the opportunities in brownfield development, and that clean up is the answer for these sites. Brownfield sites will always require more work; but for a city, seeking urban renewal, these sites cannot be pushed aside. The disregard of brownfield threatens their historical significance and our environmental responsibility. 


\section{HAMILTON'S NINE DIRECTIONS TO GUIDE DEVELOPMENT: ${ }^{2}$}

(1) ENCOURAGE A COMPATIBLE MIX OF USES IN NEIGHBOURHOODS THAT PROVIDE
OPPORTUNITIES TO LOVE, WORK AND PLAY.

(2) CONCENTRATE NEW DEVELOPMENT WITHIN EXISTING BUILT-UP AREAS AND WITHIN A FIRM URBAN BOUNDARY.

3 PROTECT RURAL AREAS FOR VIABLE RURAL ECONOMY, AGRICULTURE RESOURCES, ENVIRONMENTALLY SENSITIVE RECREATION AND ENJOYMENT OF THE RURAL LANDSCAPE.

(4) DESIGN NEIGHBOURHOODS TO IMPROVE ACCESS TO COMMUNITY LIFE.

5 RETAIN AND ATTRACT JOBS IN HAMILTON'S STRENGTH AREAS AND IN TARGETED NEW SECTORS.

6 EXPAND TRANSPORTATION OPTIONS THAT ENCOURAGE TRAVEL BY FOOT, BIKE AND TRANSIT AND ENHANCE INTER-REGIONAL TRANSPORTATION CONNECTIONS. (7) MAXIMIZE THE USE OF EXISTING BUILDINGS, INFRASTRUCTURE AND VACANT OR
ABANDONED LAND.

8 PROTECT ECOLOGY SYSTEMS AND IMPROVE AIR, LAND AND WATER QUALITY.

9 MAINTAIN AND CREATE ATTRACTIVE PUBLIC AND PRIVATE SPACES AND RESPECT THE UNIQUE CHARACTER OF EXISTING BUILDINGS, NEIGHBOURHOODS AND SETTLEMENTS. 


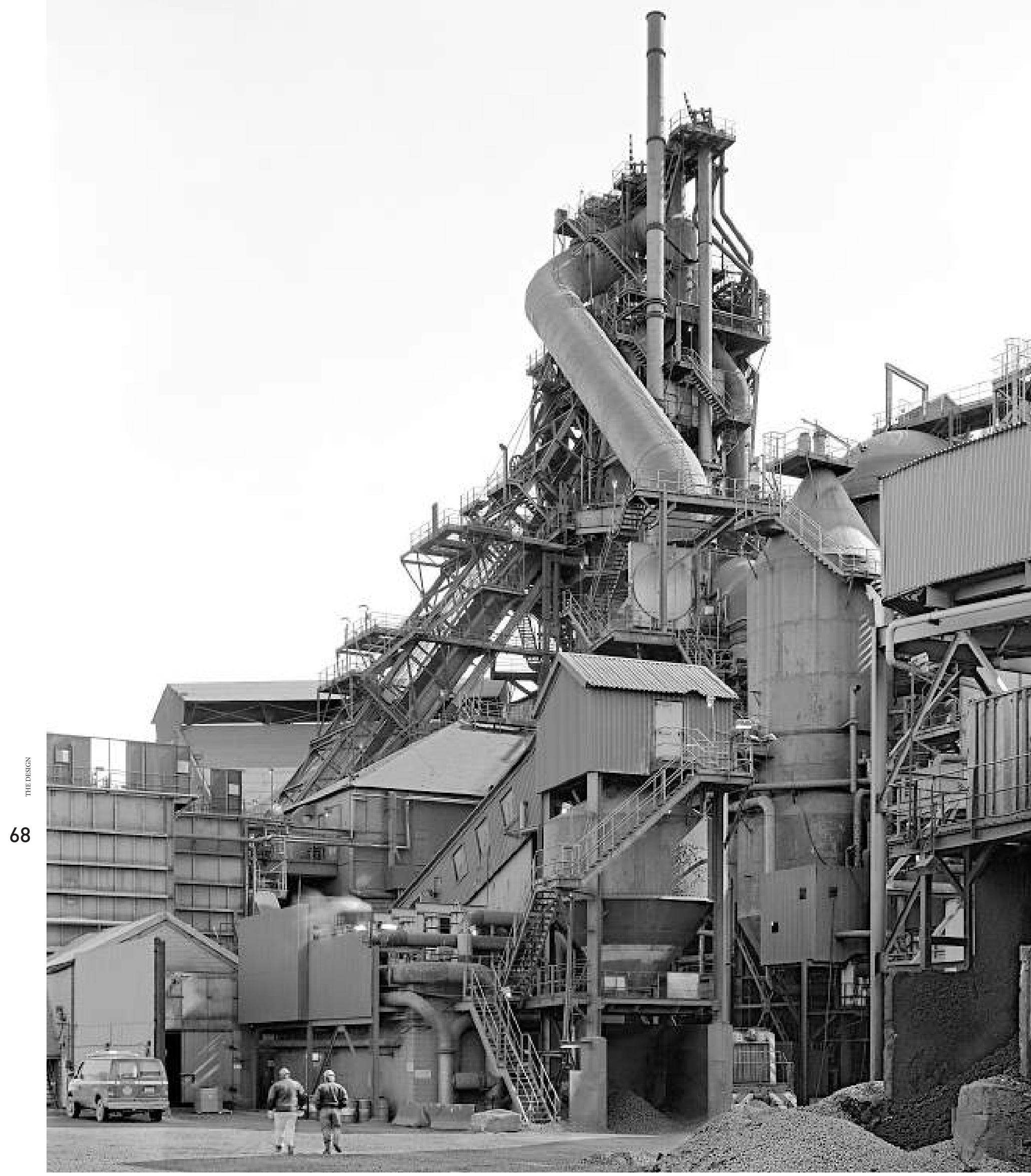




\section{(4) Landscape Remediation}

Phytoremediation is a new approach to cleaning brownfield sites. As a financially conscious method of remediation, phytoremediation uses plants to remove, downgrade or improve the effects of contaminants from water and soil. Plants are selected according to their ability to treat contaminants and thrive on the chosen site. The benefit of phytoremediation is in its adaptability for a multitude of climates and contaminants while providing a medium for landscape design. Unlike alternative methods of remediation that remove or bury contaminated soil, phytoremediation directly addresses the hazardous environment and transforms it into a habitable space.

\section{(- Affordable Housing}

Approximately one-third of Hamiltonians are priced out of owning and renting a house in the current market, and the government struggling to provide adequate assistance for all in need. A new approach to affordable housing with long-term ambition is crucial to the city's future growth. Subsidized rental housing has been the Canadian model of social housing for a longtime; although successful in providing a physical house it enables longterm dependency on assisted living. Ownership has been the model coveted by the North American lifestyle since its colonization. If the property is affordable, home ownership is beneficial for the occupants and the city at large. For the resident, ownership will foster a sense of pride and responsibility over their personal space thus alleviating the need for the city to maintain building property. Moreover, affordable housing promises physical and financial security through the personal accumulation of capital and reduces the unpredictability of social housing demand on the city. With housing incentives provided by the Canadian Housing and Mortgage Corporation, Steelcity Living advances a $\$ 100,000$ house aimed at providing adequate housing for low-income residents earning $\$ 25,000$ annually. 


\section{Project Timeline}

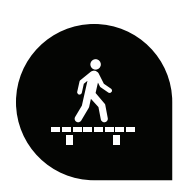

WATERFRONT

PUBLIC ACCESS ONTO SITE

WALKING PATHWAYS THROUGH SITE TO VIEW BUILDINGS FROM A DISTANCE WATERFRONT INTERVENTION

COMMUNITY CENTRE/SPORTS COMPLEX IN EXISTING BUILDING

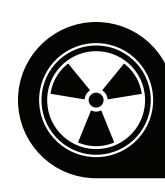

PHYTOREMEDIATION

MORE INTENSIVE REMEDIATION FOR WATERFRONT

PHYTOREMDIATION BEGINS ON SITE VIA TREE FARM

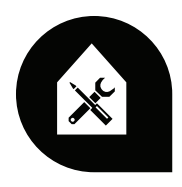

DOFASCO

DOFASCO BEGINS CONSTRUCTION OF PREFAB

HOUSING UNIT ON EAST SIDE OF THE SITE

70

SUPPLIES UNITS TO FIRST HALF OF THE HOUSING SHEDS ON STELCO SITE

HOUSING

BEGIN TO INHABIT EXISTING SHEDS WITH HOUSING UNITS AND SUPPORTING COMMERCIAL PROGRAMS

EXPENSION OF WALKING PATHS AS SOIL BECOMES LESS

TOXIC WITH PHYTOREMEDIATION 


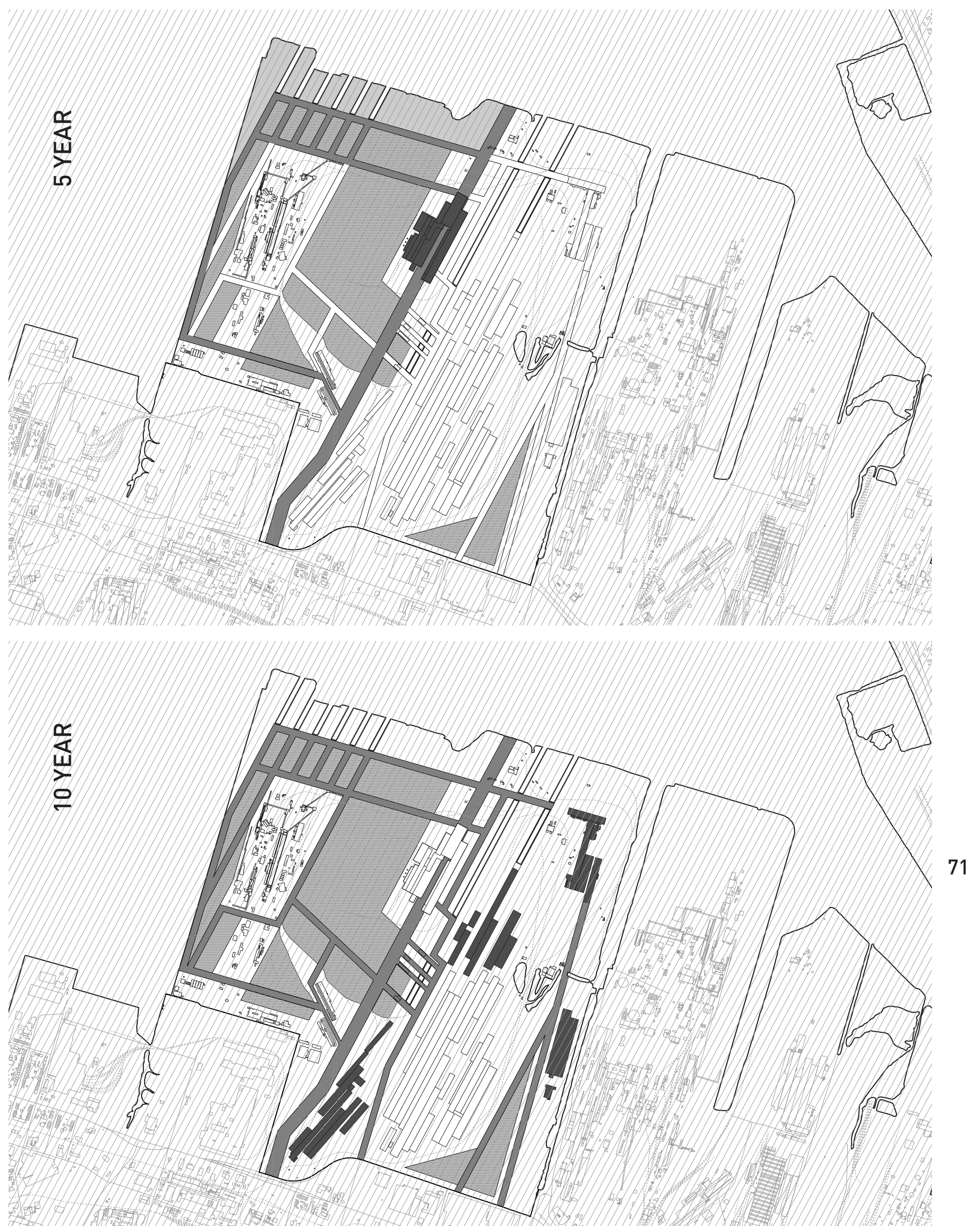


POST INDUSTRIAL LANDSCAPE

FOLLOWING REMEDIATION BOTH, INTENSIVE AND PHYTOREMEDIATION

INDUSTRIAL LANDSCAPE OPENS FOR PUBLIC INTERACTION ON WEST SIDE

HOUSING

REMANDING SHEDS ARE OCCUPIED WITH COMMERCIAL AND HOUSING UNITS

HOUSING CONTINUES TO BE BUILT BY NEIGHBOURING FACTORY, DOFASCO

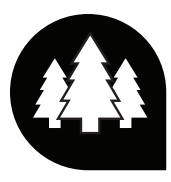

TREE FARM

FOLLOWING 20 YEARS OF PHYTOREMEDIATION THE TREE FARM

72

IS OPENED FOR PUBLIC HABITATION AND ECONOMIC PRODUCTION

SITE IS COMPLETELY OPEN AND BUILDINGS ARE AT FULL CAPACITY 


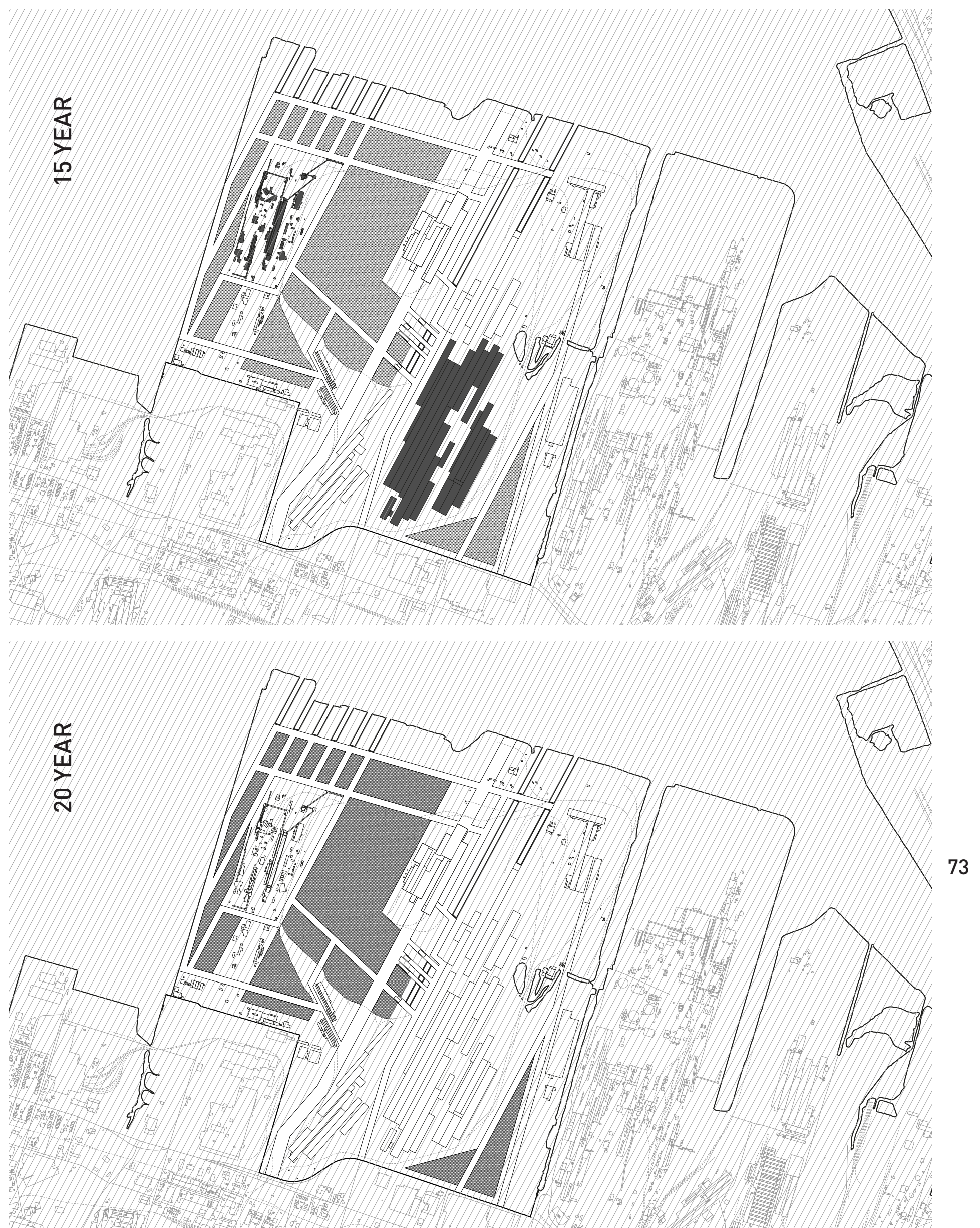




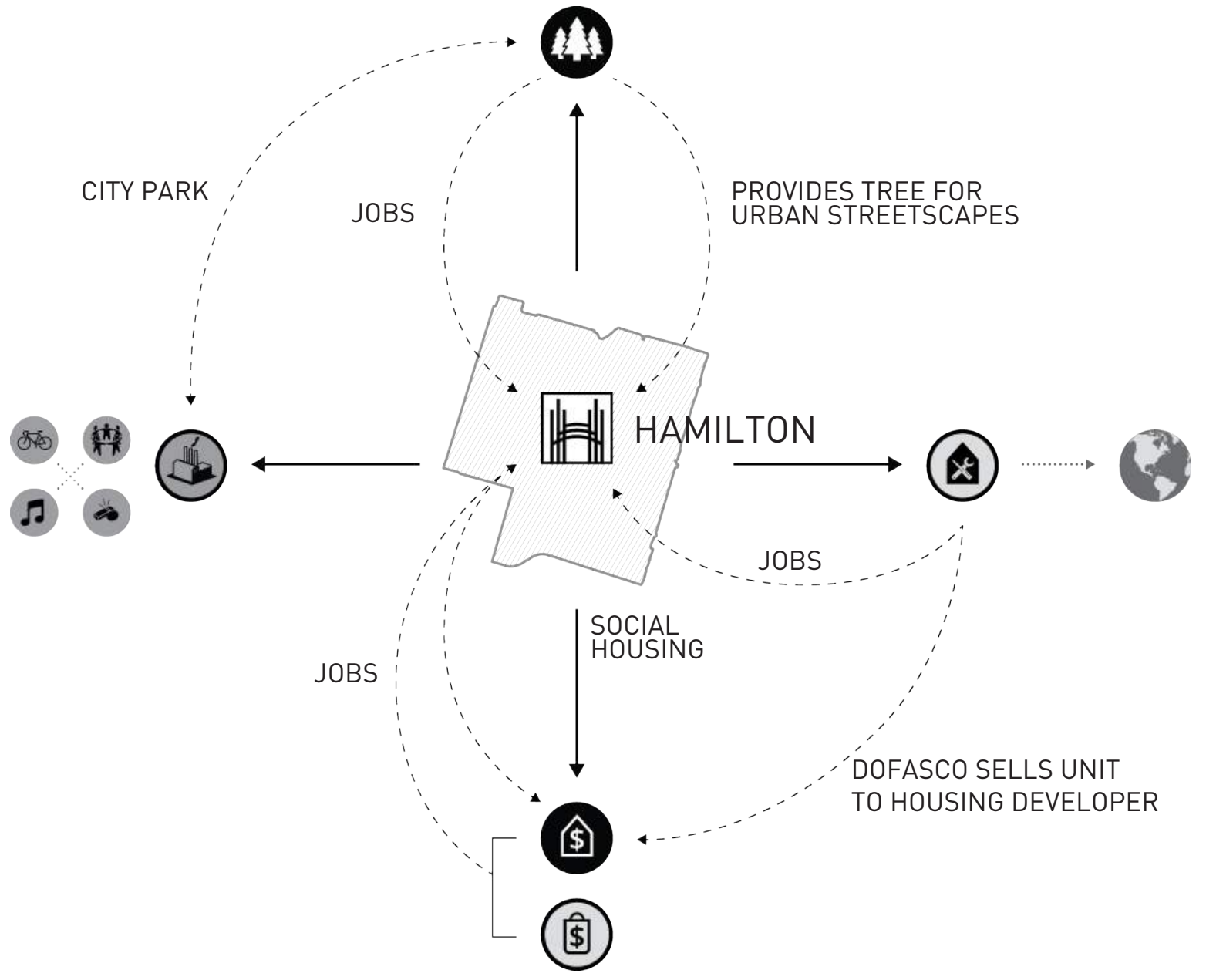

74 


\section{Financial Relationships}

Essential to the success and feasibility of affordable home ownership are the relationships between the public and private sectors. Similar to the desire to move affordable housing from a public responsibility to a private opportunity, the construction of this project is to be lead by private developers. Hamilton would initially purchase the land from U.S. Steel and divide the land between all private parties involved.

\section{(x) DOFASCO}

The east side of the site is devoted to the production of the $\$ 100,000$ housing units, manufactured by the neighbouring steel factory Dofasco. The link between the neighbouring steel factory provides essential materials for the construction of the housing unit, including the steel frame and aluminium siding. Its location on the site offers the opportunity to sell the units globally. Following construction, the units are first sold to the housing developer who then sells them to the new residents via the community housing association.

\section{(3) 0}

\section{HOUSING and COMMERCIAL DEVELOPER}

This primary developer is responsible for adapting the existing sheds to house affordable and market units, in addition to the construction of the new commercial district. The new residential construction and commercial programs provide valuable jobs for individuals living in the new Stelco and the surrounding neighbourhoods.

\section{(4) TREE FARMER}

The third opportunity for job creation is the tree farm. Serviced by a private owner, the tree farm also supplies the city with the appropriate trees for uses throughout Hamilton. Its central location serves as a flexible landscape extending the public park for large events and acts as a transitional space between the new residential sheds and the public park.

\section{LANDSCAPE DEVELOPER}

The final contributor is a landscape designer, funded by the city of Hamilton, tasked with preserving and adapting the west edge of the site that includes the post-industrial park, inactive rail lines and new urban streetscapes. 
1 Niall Kirkwood, Manufactured Sites (London \& New York: Spon Press, 2001), 162.

2 "Nine Directions to Guide Development," Urban Hamilton Official Plan (2009): A.2,2, accessed March

30, 2015, http://www.hamilton.ca/NR/rdonlyres/0A939735-8827-4D79-8C54-B01970515106/0/

UHOPVol1PoliciesrevOct2013.pdf.

3 Adam Carter, "What's next for Hamilton's brownfields?" CBC Hamilton, July 16, 2013, accessed March 30, 2013

http://www.cbc.ca/news/canada/hamilton/news/what-s-next-for-hamilton-s-brownfields-1.1411099.

4 Ibid. 

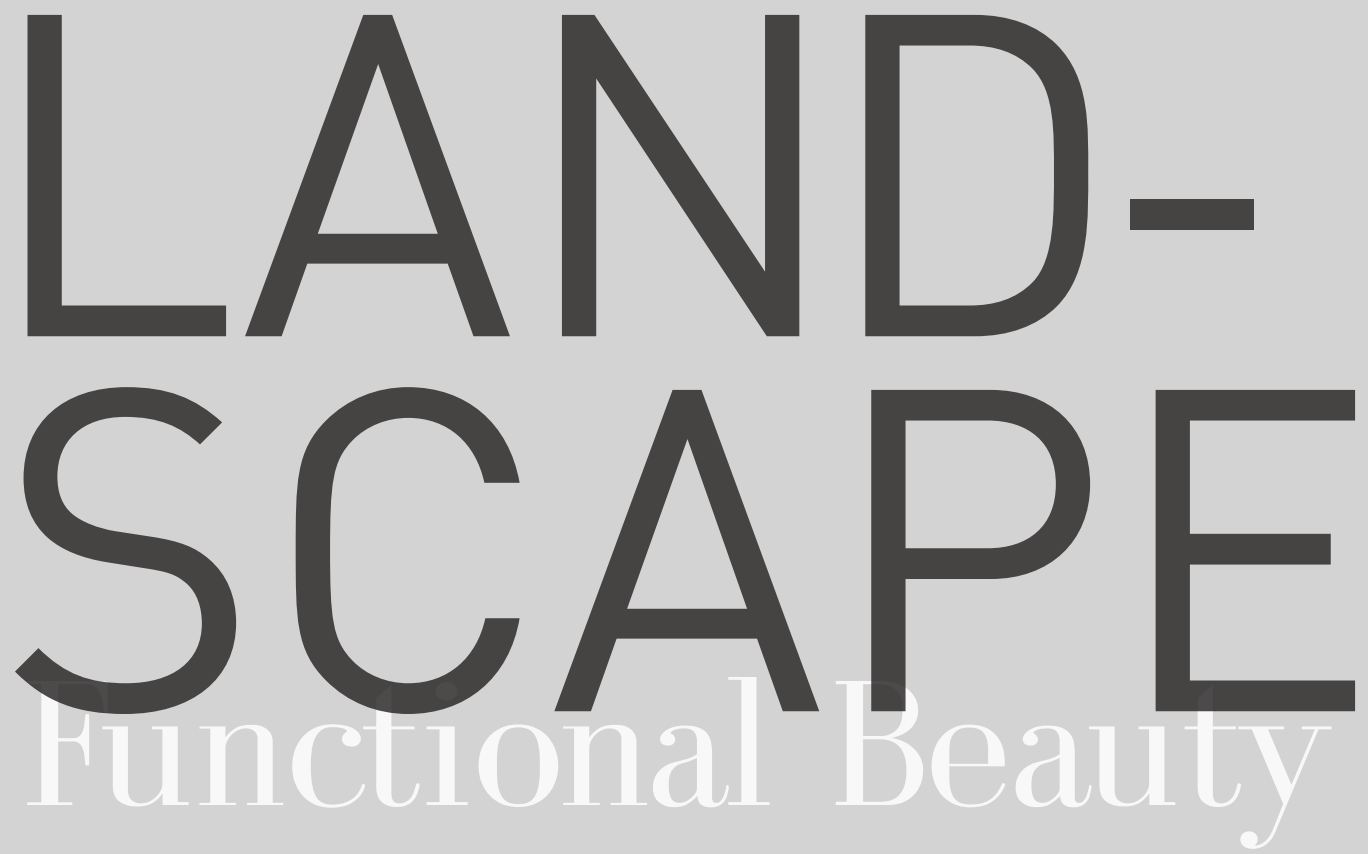

78 


\section{Memory Scapes}

Landscape has been a statement on humankind's idyllic view of nature and its ability to control it. Idealizations like French Romanticism or the English Picturesque movement led to the creation of distinctive parks. As symbols of a previous cultural history, these landscapes cannot be recreated today.

Industry brought great change to the physical and cultural landscapes of Canadian cities. Manufactured sites showcase our ability and desire to dominate the landscape in the process of production and an economy based on consumption. The success of the postwar economy slowly dissipated as the industrial market transitioned to global competition. Consequently, many manufacturing sites have been abandoned.

Many projects seeking to utilize abandon post-industrial sites undertake a complete destruction of the existing structures and removal of contaminated soil in order to develop as quickly as possible. This displacement ignores environmental responsibility and threatens the historical significance of industrial sites.
For more than a century, Stelco has defined the skyline of Hamilton. The other major mark on the city's skyline is the escarpment, ridden with river systems and waterfalls. This terrain succeeds in providing the city with ample amounts of green space; however, the uneven landscape limits its potential as a social place. Other places such as Gage Park have failed to provide the requirements for citywide events and festivals, such as the Festival of Friends. With the steel industry's decline, questions and ideas of physical development of the city's brownfields are inevitable. These underutilized sites provide a great opportunity for a new type of social meeting place. The synthesis of the physical and symbolic histories of Hamilton's industry form a backdrop for public engagement.

The design preserves a portion of the old factory on the northwest edge of the Stelco plant for open programmed park, the largest urban park in Hamilton. The site's location and proximity to downtown is ideal for a variety of cultural and social events, including but limited to festivals, outdoor concerts, and physical activities. In a Park of this size, location and design will be beneficial for events such as the Juno Awards, held this past March or the Pan Am Games 2015, an event Hamilton had to forfeit to due to a lack of space and support. 


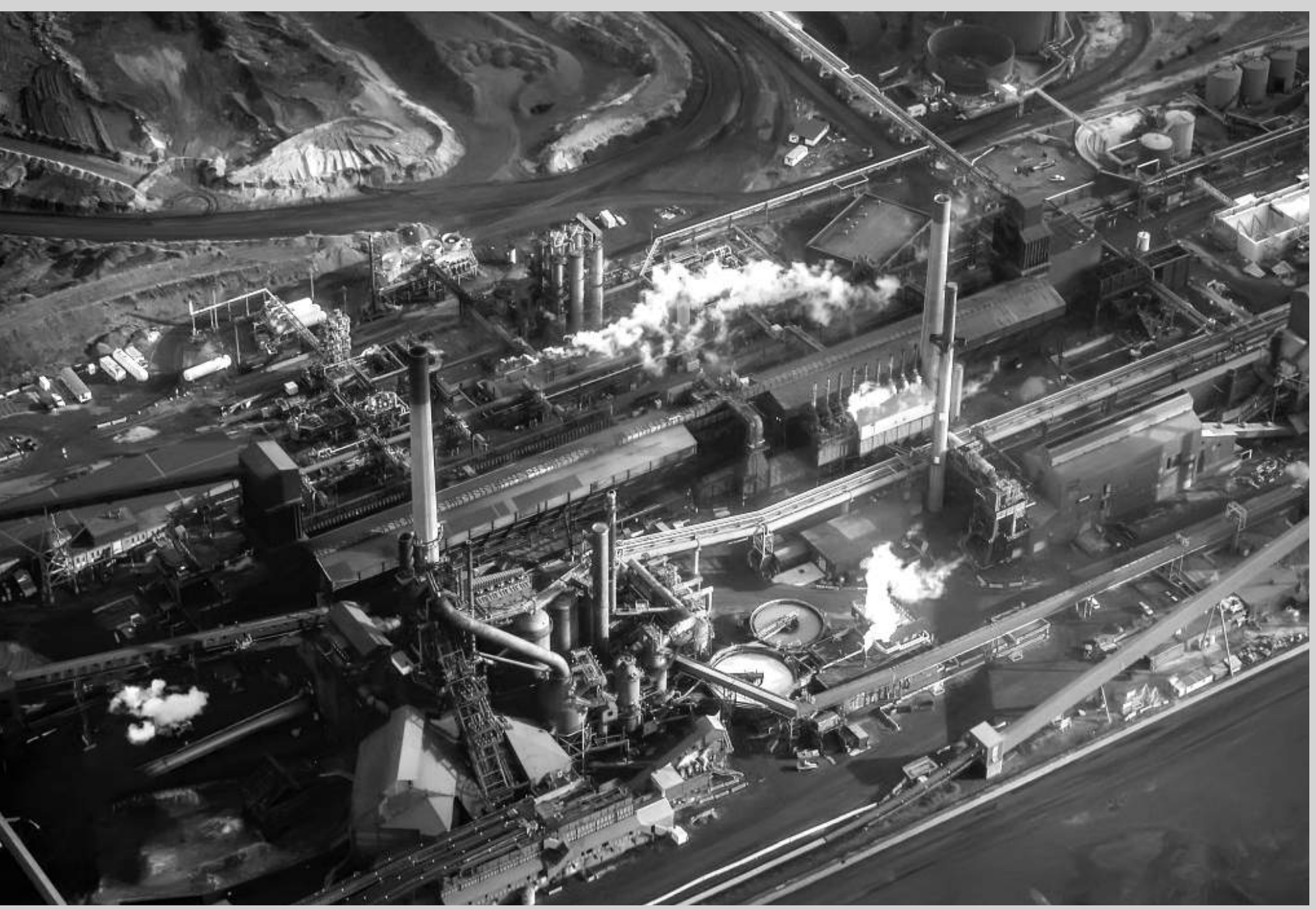

The Stelco blast furnaces represent the first step in the long process of steel manufacturing, and Steelcity Living uses their form as an iconic symbol for the cultural identity of Hamilton. Protection of this industrial remnant stands as a representation of its historical significance. The 1970s publication Pardon My Lunch Bucket paints the picture of the company's significance: "Stelco - the Steel Company of Canada - is the mother hen of the nest. With 21497 employees and producing 4801000 tons of steel, it is by far the largest of Canada's basic steel companies." 


\section{Figure Ground Studies}

Through figure-ground studies of the

Stelco plant, the pattern, size, direction and

shape of the existing buildings influenced

the design of the surrounding landscape.

The aim is to cement, in abstract drawings,

the importance of the architectural

language of industrial development and

its mark on the development of the city

of Hamilton. The magnitude of the site

is apparent when the contrast between

the scale of the city and the scale of the

factory is highlighted. These drawings, in

redefining by redrawing the many scales

of Hamilton, raise a critical question: how

to integrate the scale of urban habitation

without loosing the beauty of the industrial

sublime? 


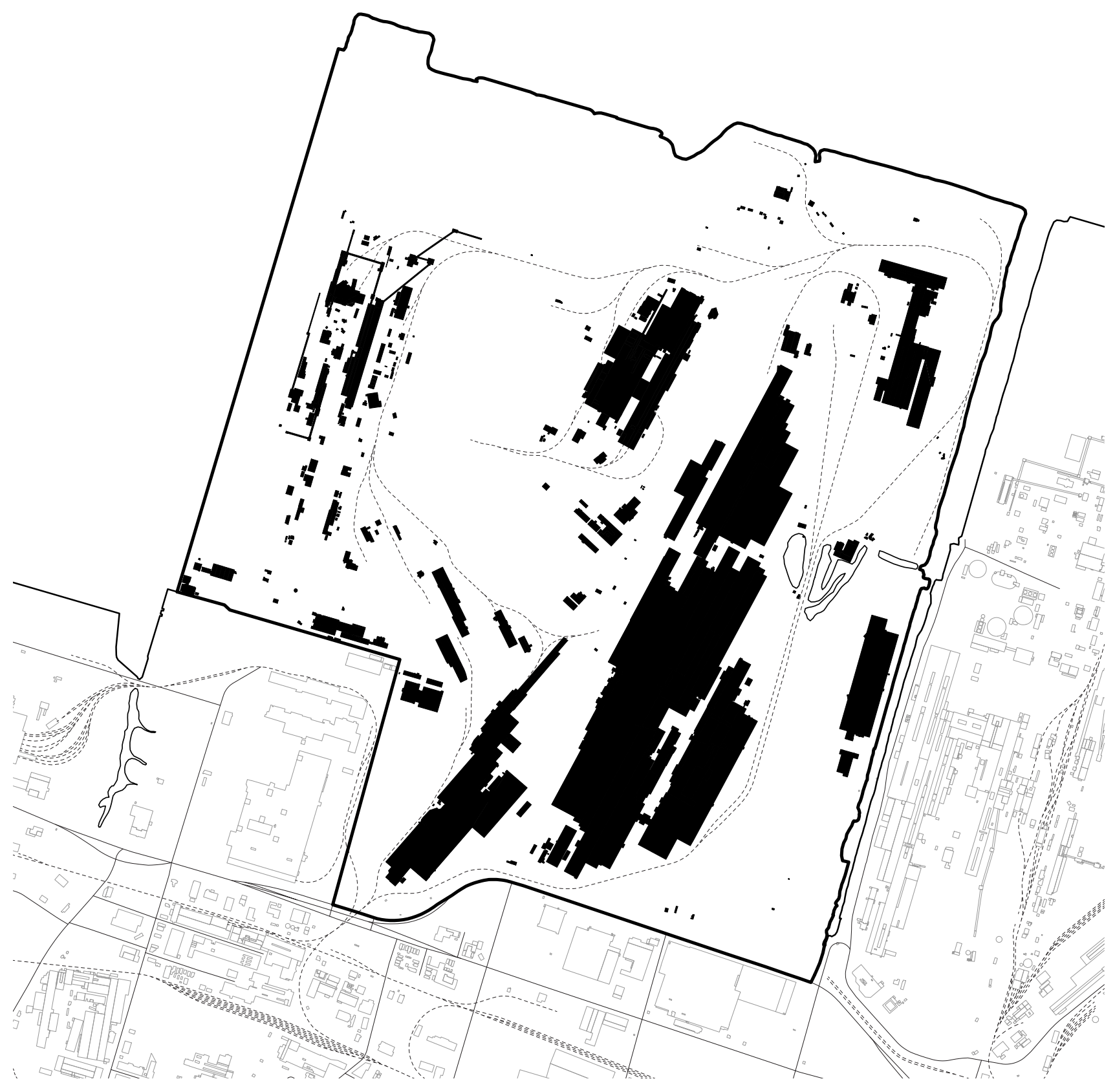




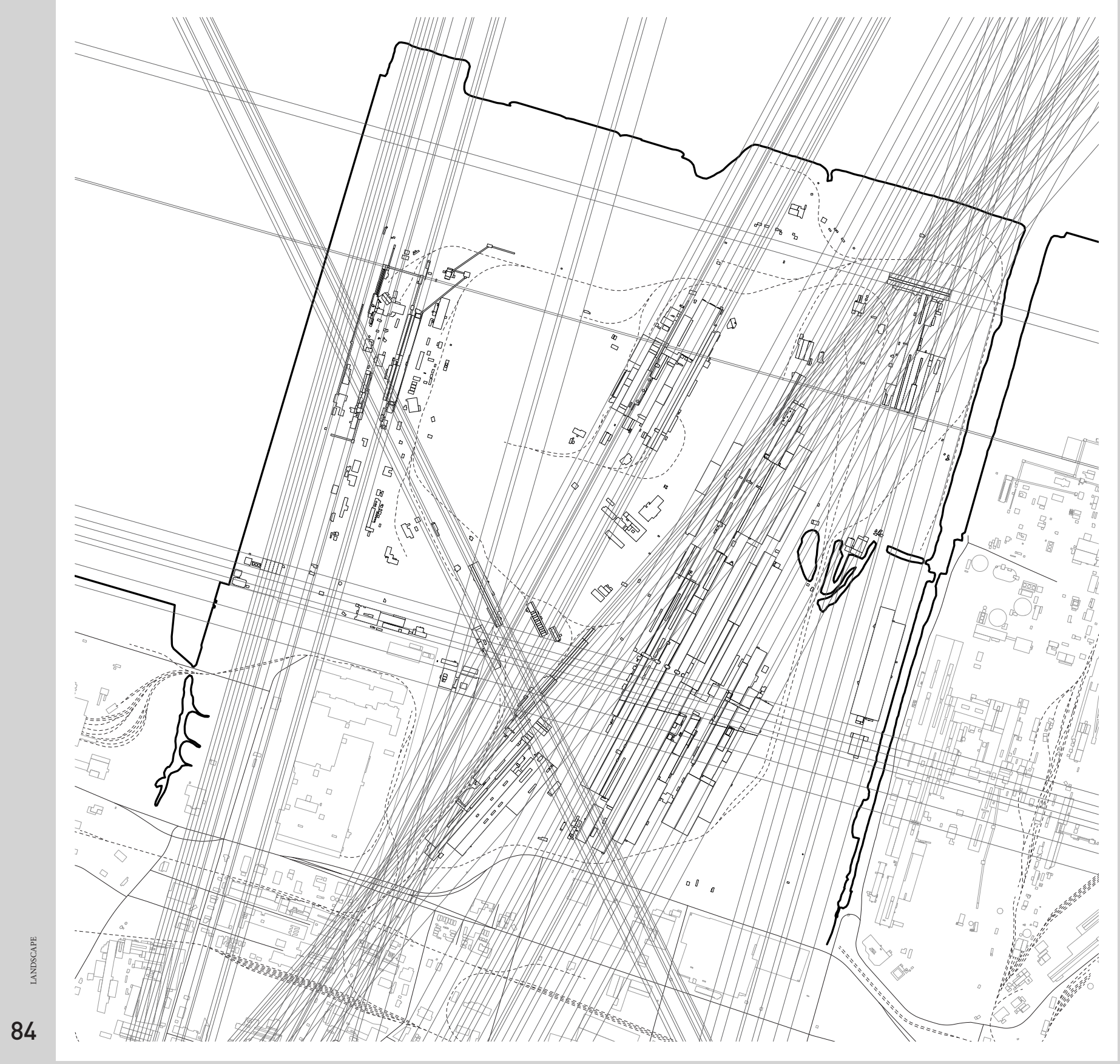




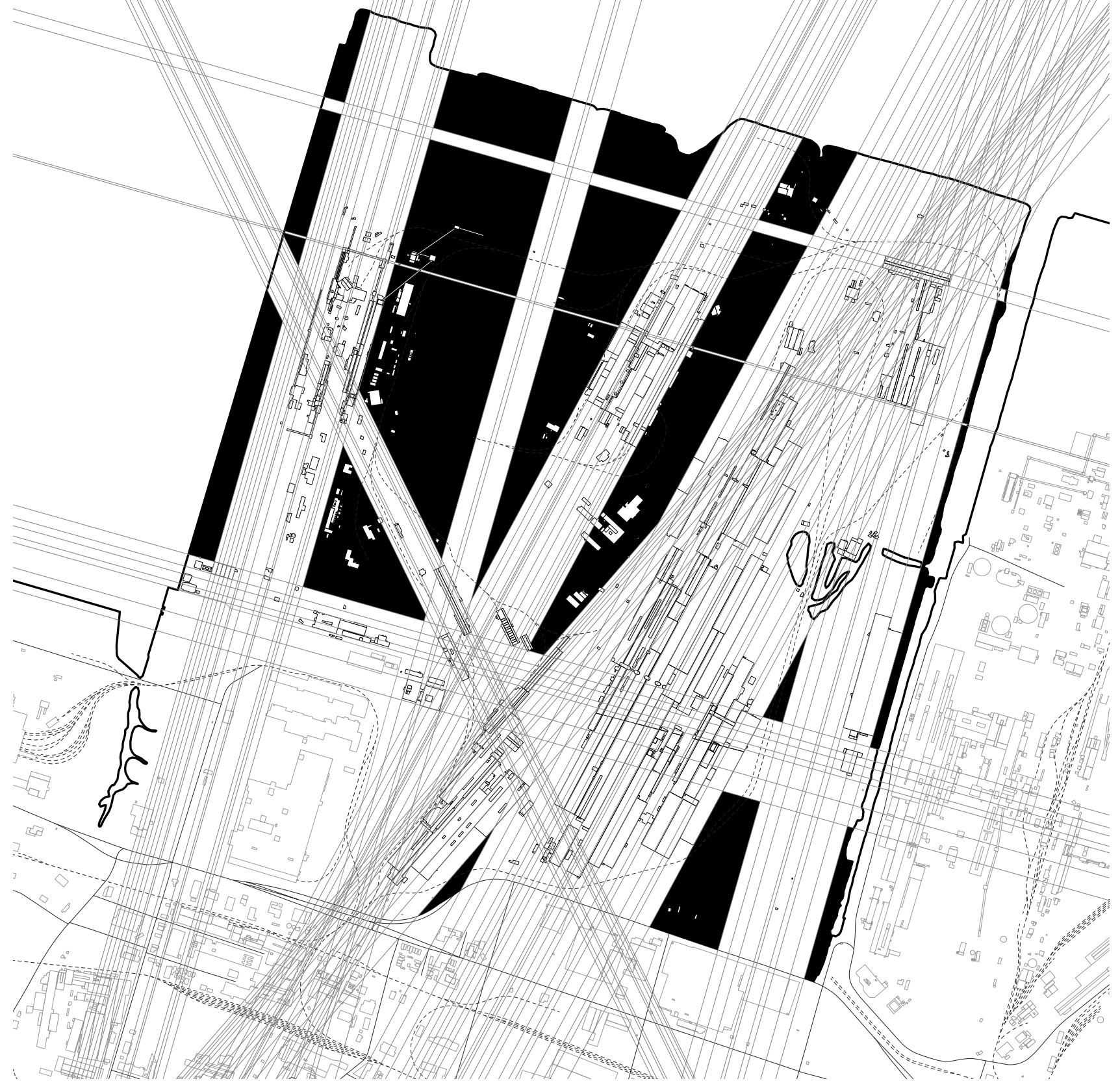




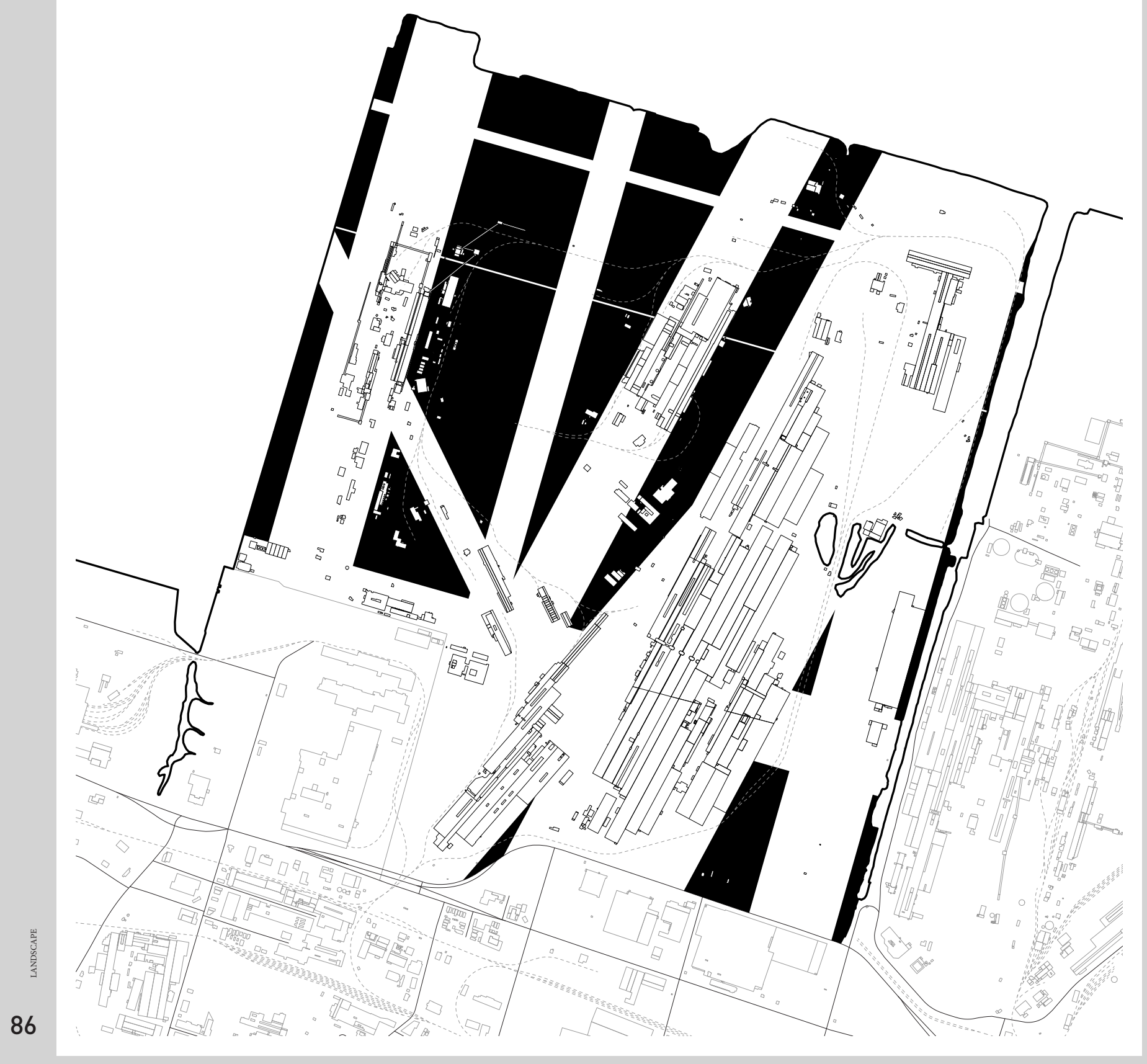




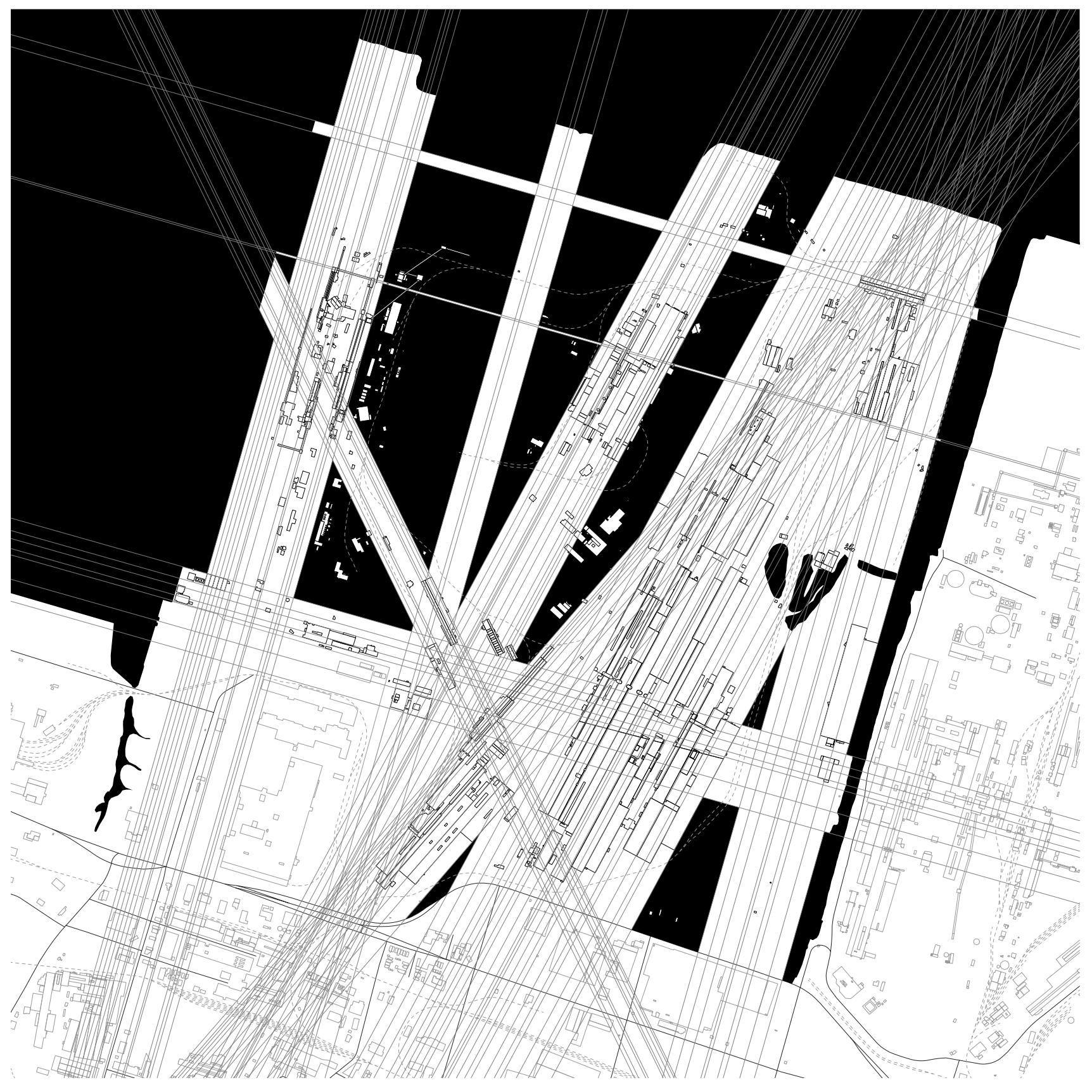




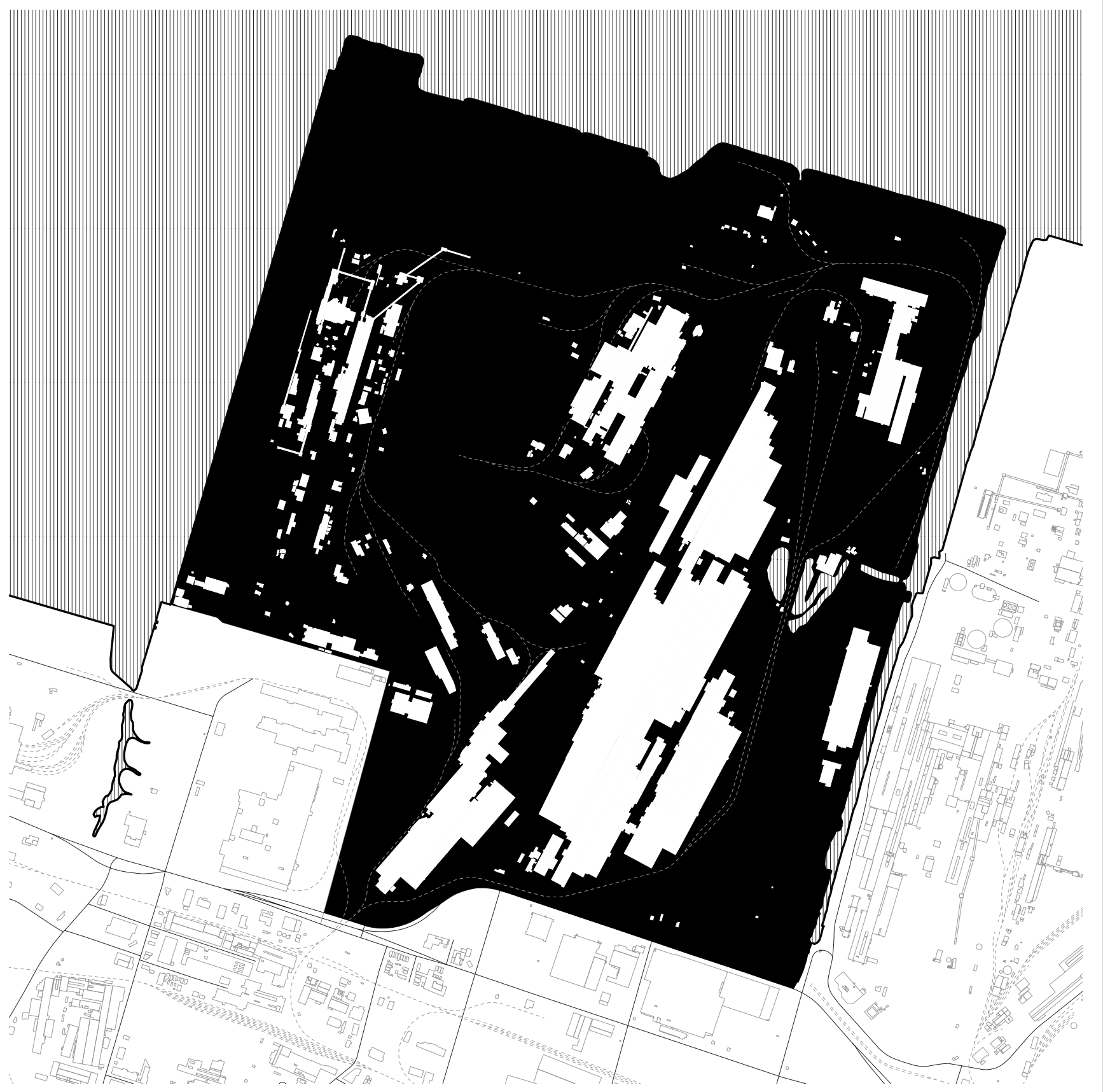




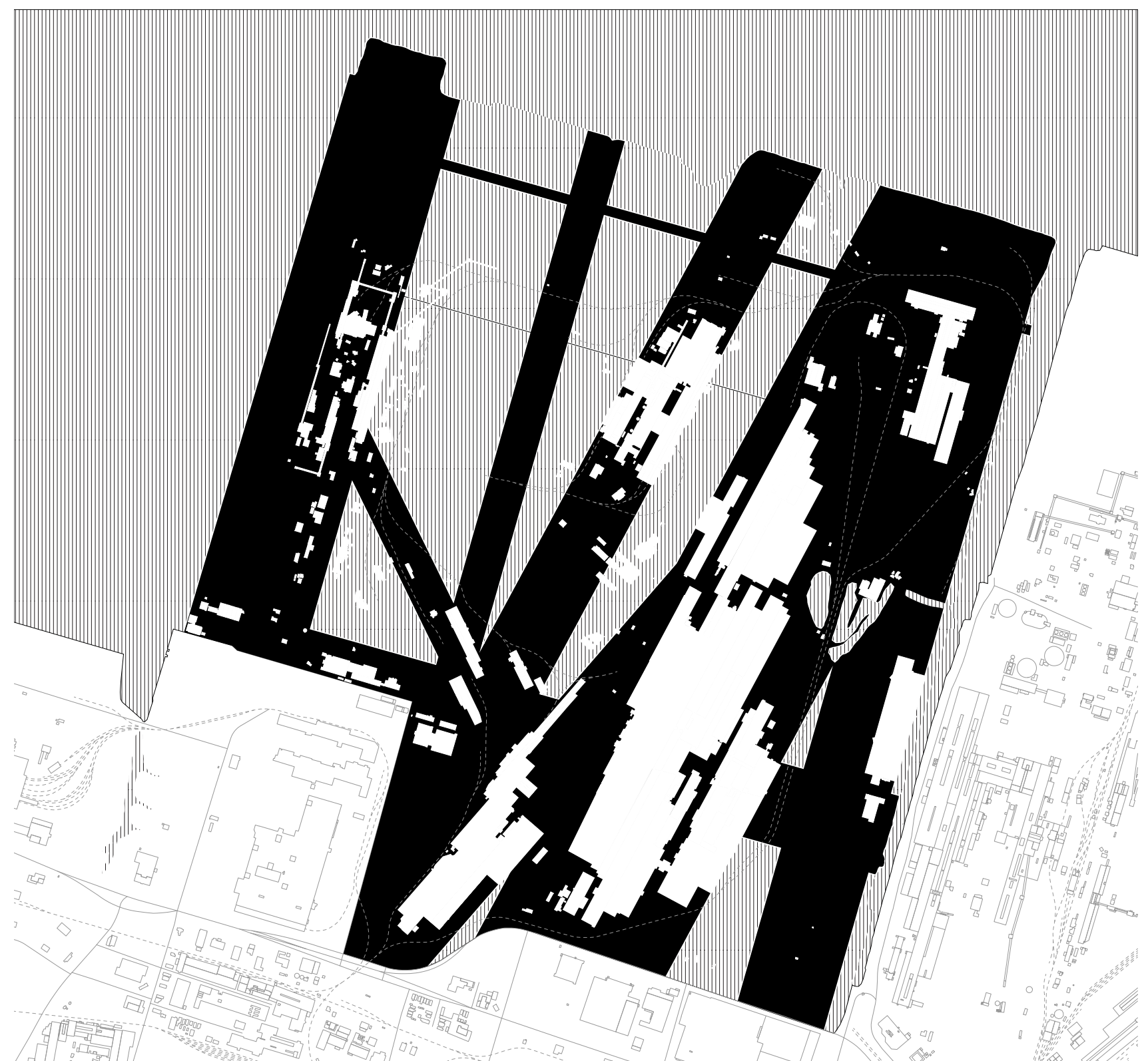




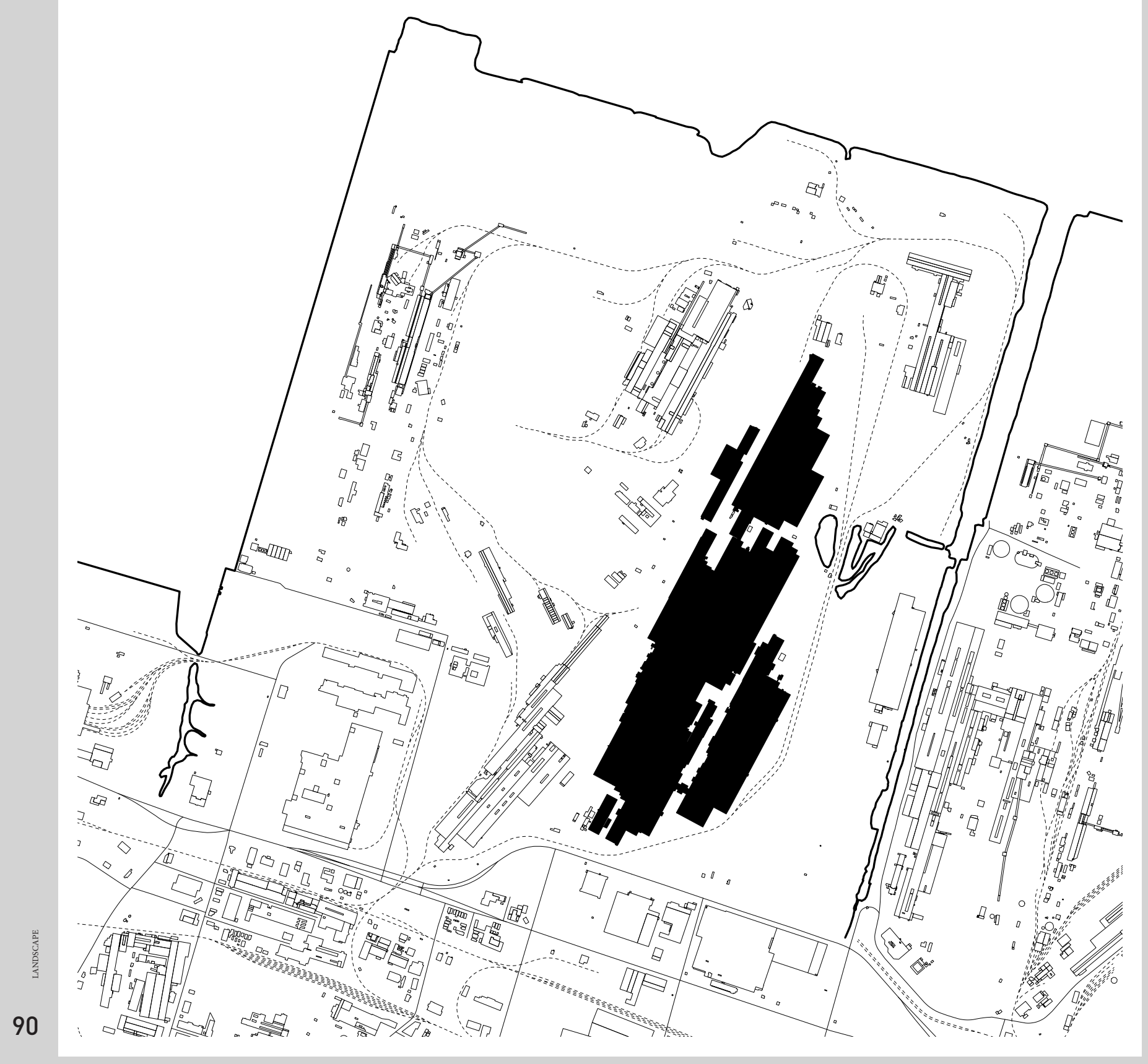




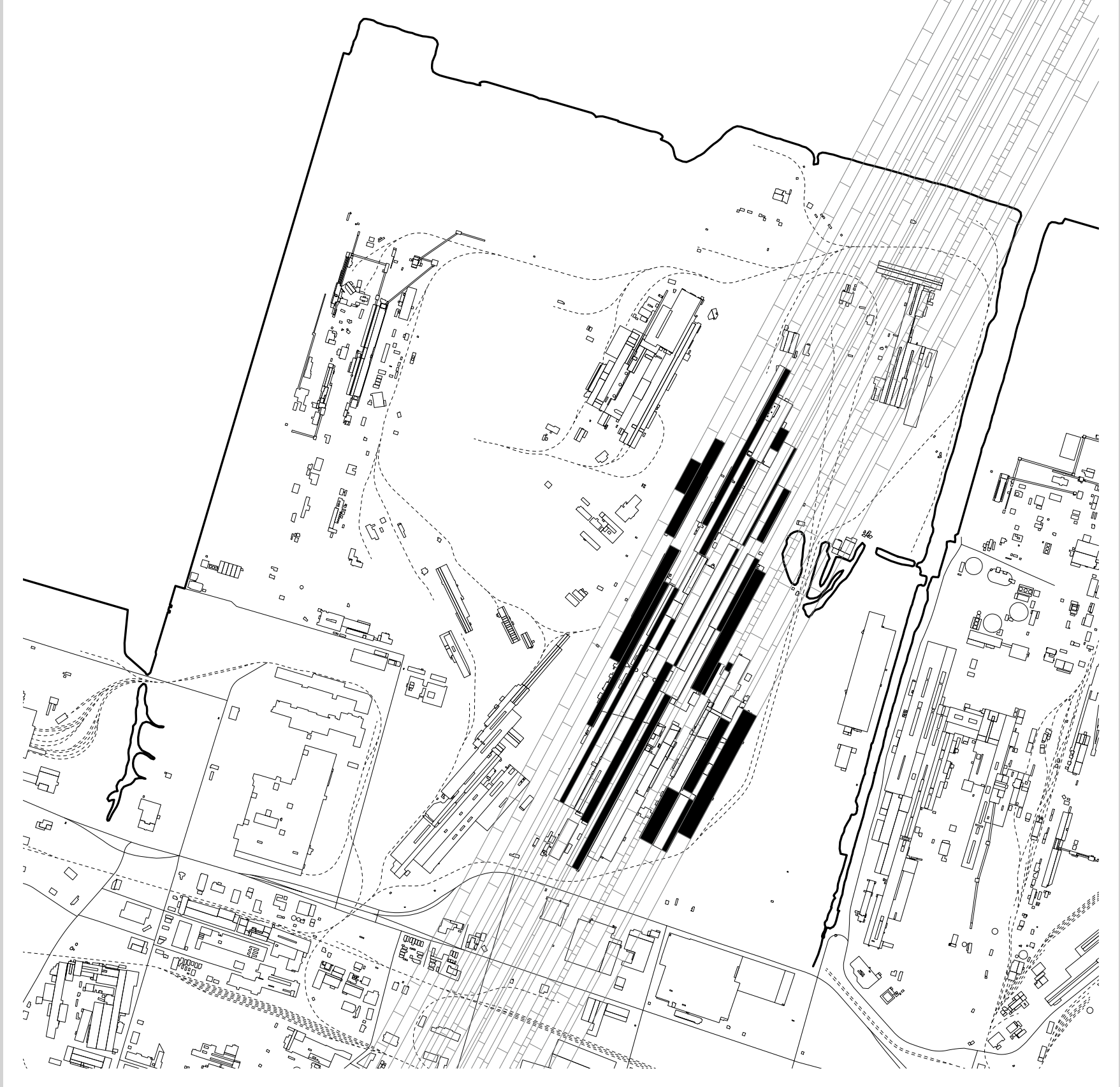




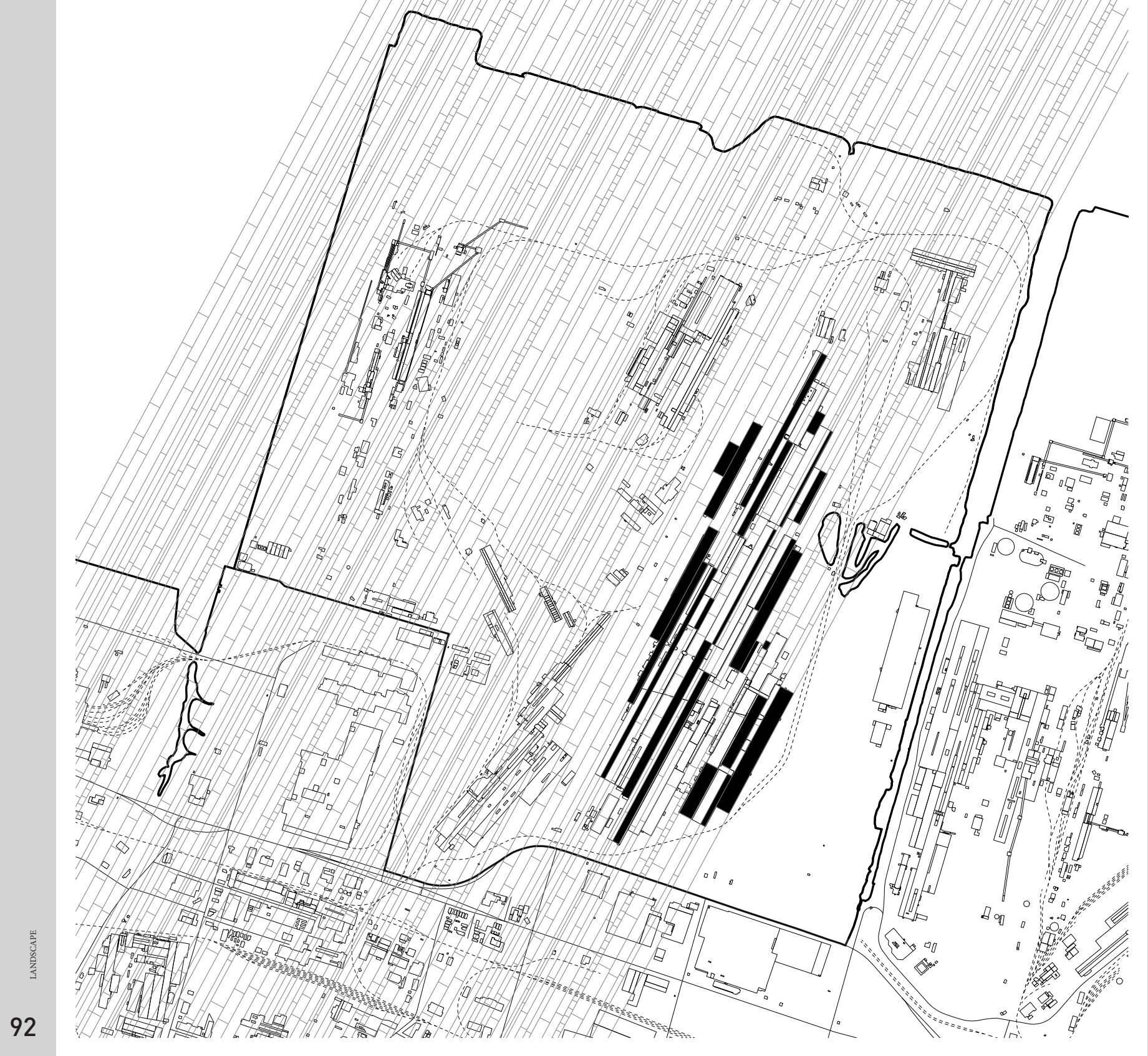




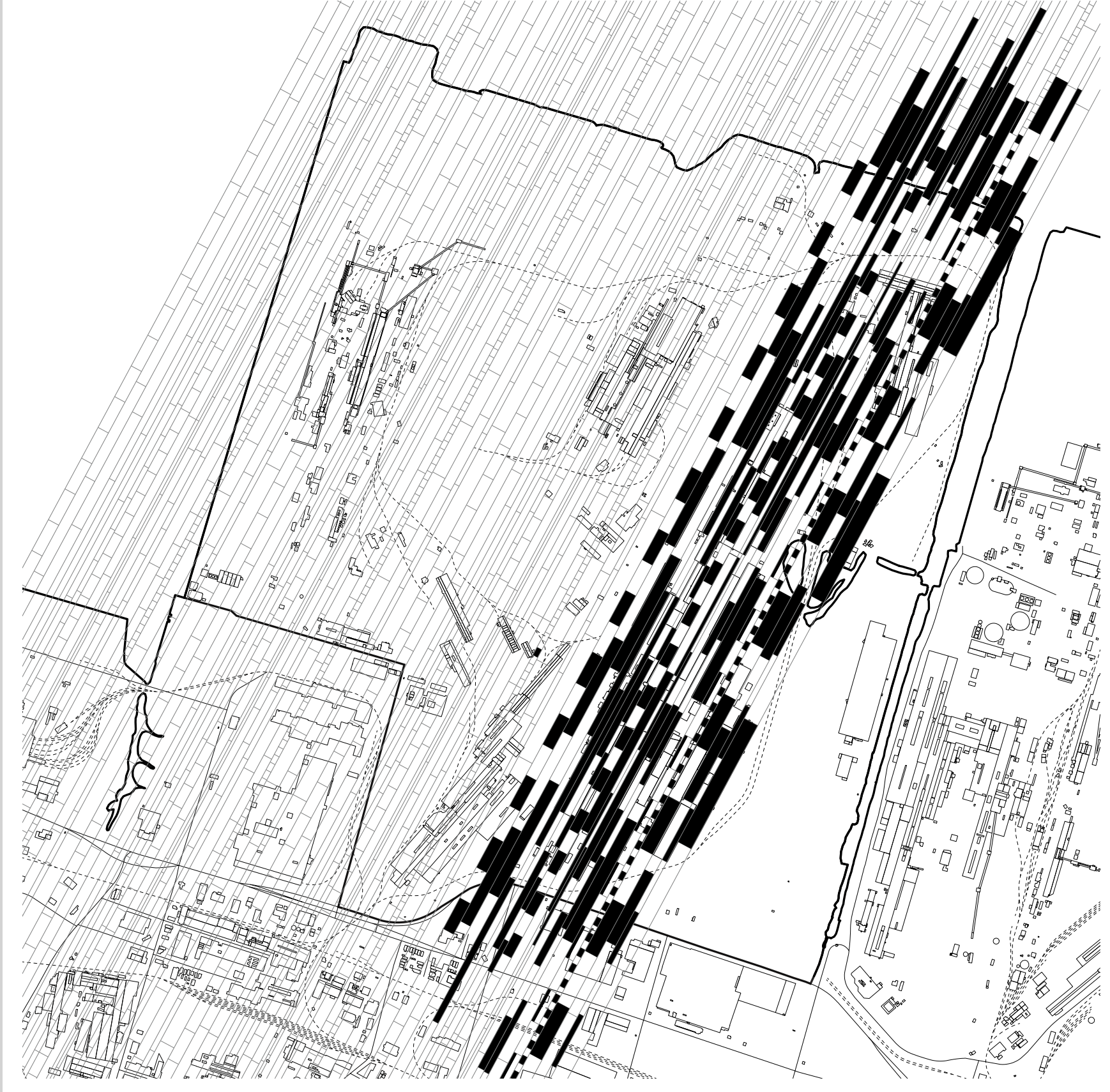




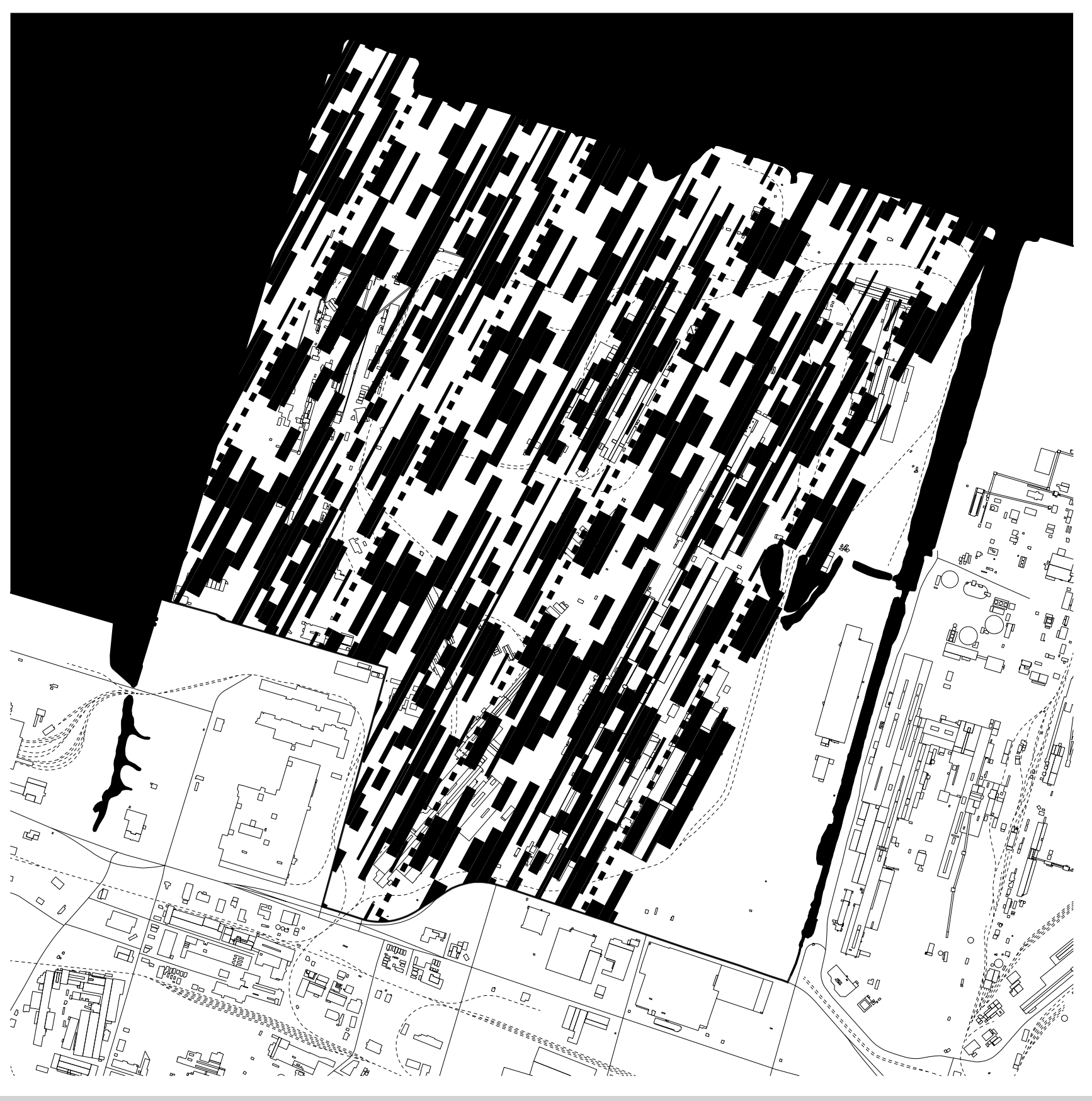




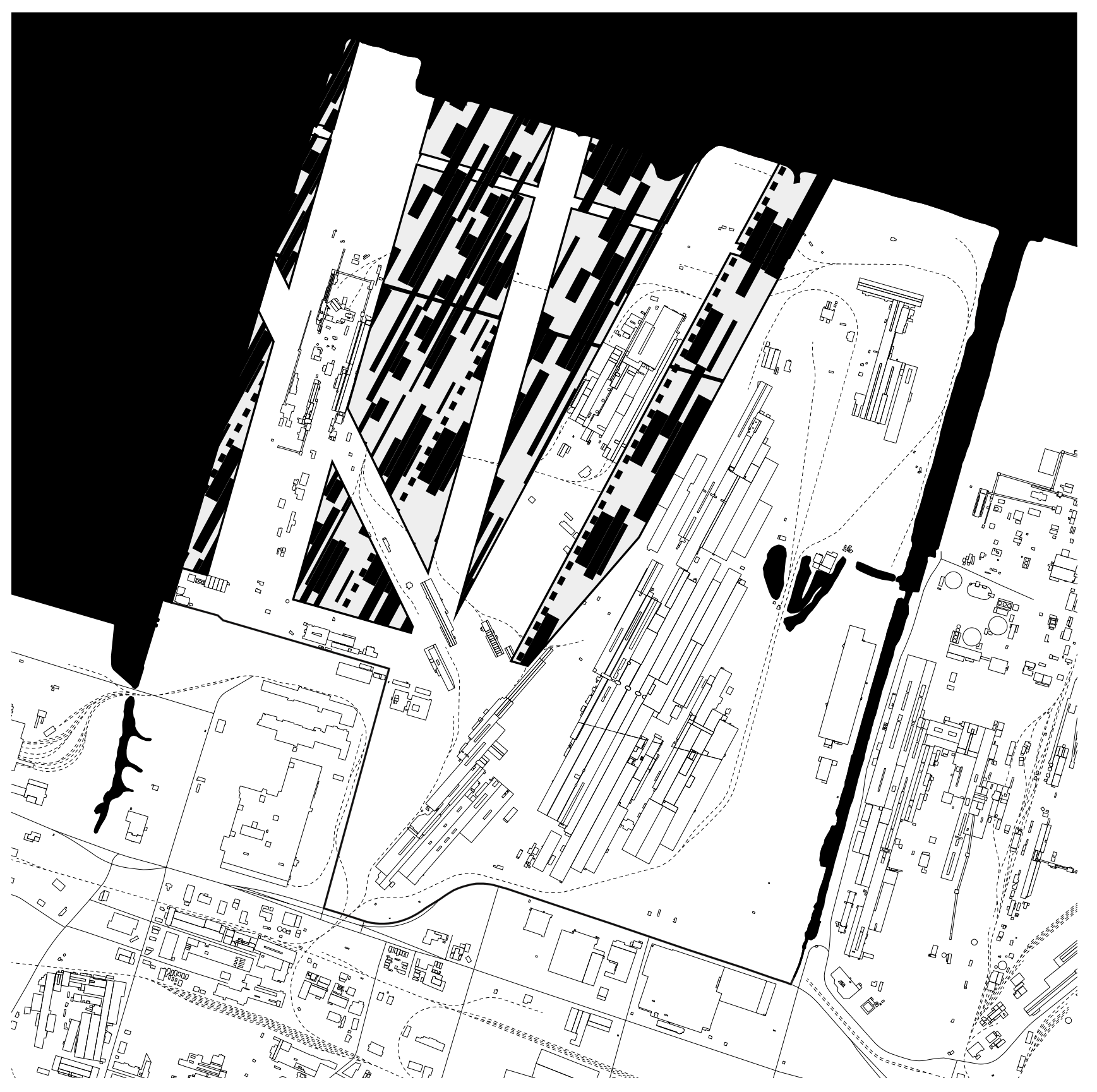




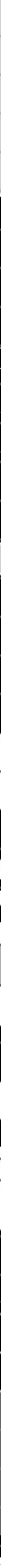




\section{Physical Model}
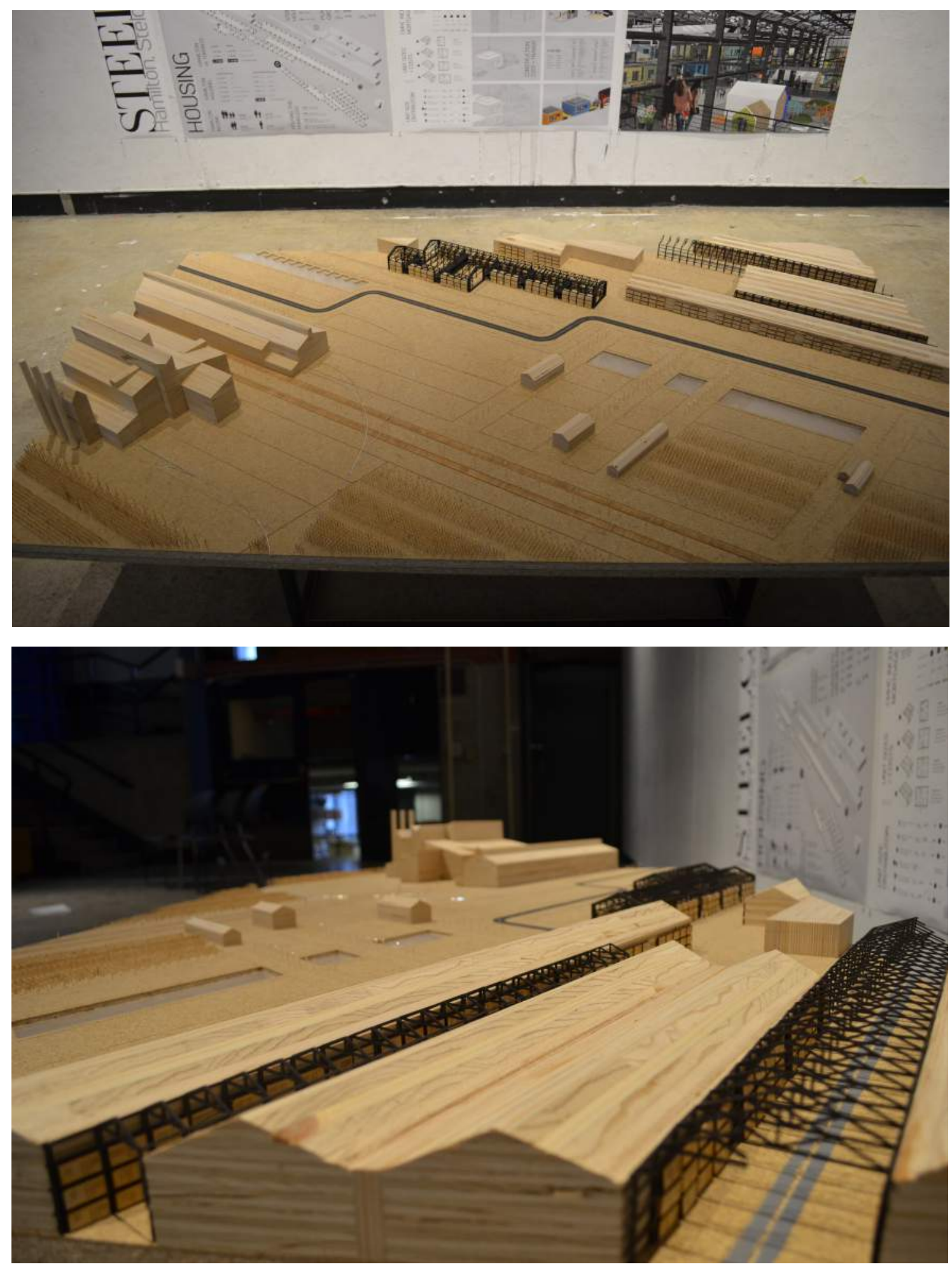

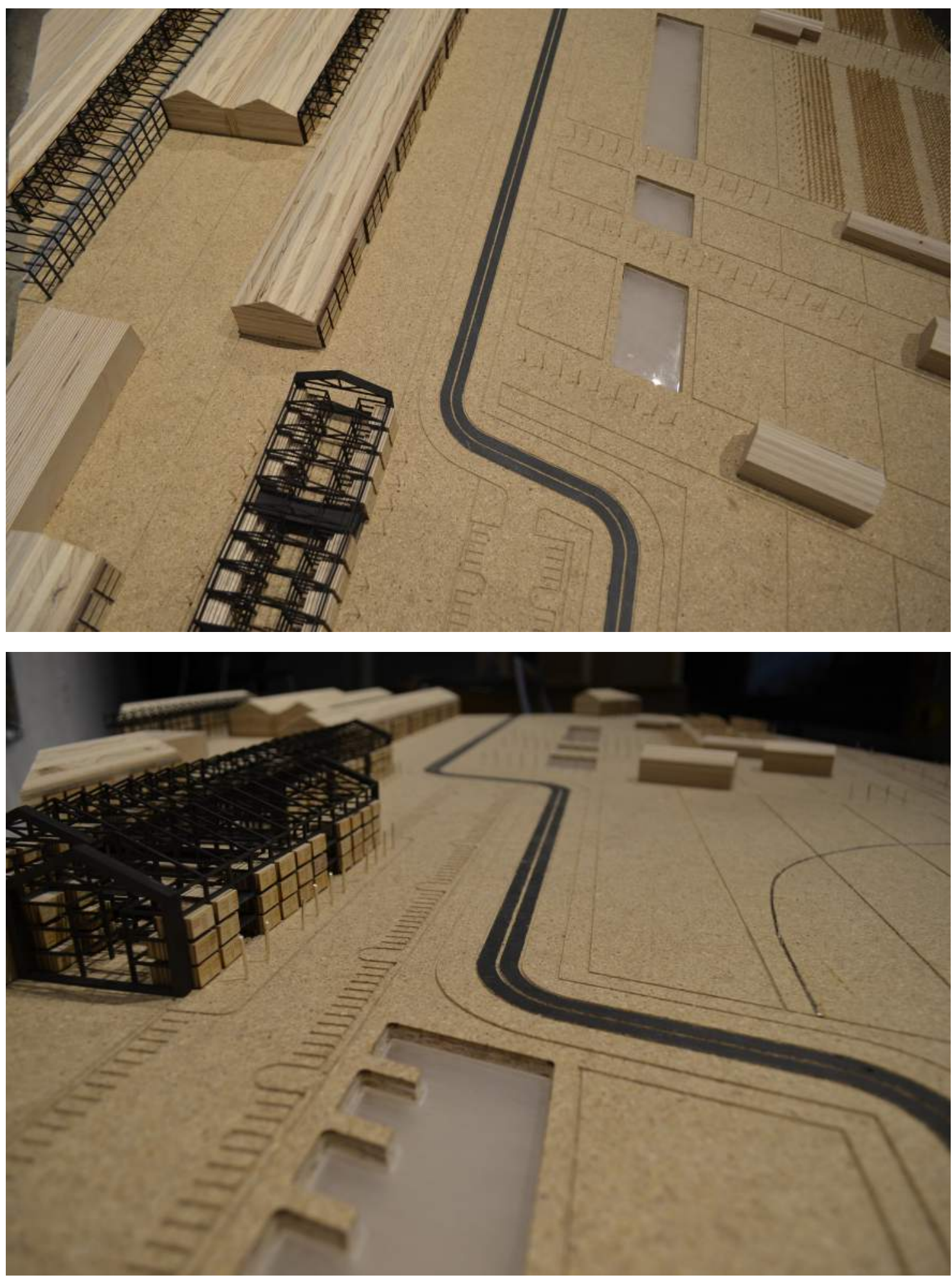


\section{(4) Tree Farm}

The new vision for Hamilton's industrial park on the U.S. Steel site is that of an integrated approach, profiting from the conscious layering of preservation, remediation and ultimately adaptation. It is an active and functional landscape, slowly changing the toxic state of the site to construct a new landscape design that provides benefits to communities through work and play. Programmatically, an urban tree farm is an industrial scaled business, a form of urban agriculture on a large scale. A tree farm requires invasive labour for a short period of time, while most of the work is waiting. With little industrial hazards, this presents the site with a unique opportunity to encourage public enjoyment in a dynamic landscape.

The integration of an urban tree farm provides four key benefits in its adaptation: remediation, employment, urban

application, and public landscape. As a working landscape, the tree farm physically transforms over time through growth and seasonal change. In close proximity to the blast furnace park it would be an extension of the community meeting space. As a productive farm, it would supply trees yearly to support Hamilton's street tree program, an initiative to push tree planting in parks, residential neighbourhoods and urban streets. In addition, the purposed program would provide new opportunities for jobs in agriculture and the city's landscape department. Participation through employment will nurture a sense of pride and belonging to the site's history and its current purpose in Hamilton's physical and social environment. In the process of a five-year growth cycle, the trees provide a fundamental service for the remediation of industrial contaminants present in the soil. Through the slow process of phytoremediation, plants transform hostile brownfield sites into habitable spaces.

With phytoremediation as the catalyst for landscape design, it answers a concluding not in Pardon My Lunch Bucket. ${ }^{2}$ 
"Surely, somewhere in the planning of the future city, there's room for a bit of green, open space and lush foliage where people can walk and sit and get away from the concrete downtown. We hope so, any way."

PARDON MY LUNCH BUCKET 


\section{Phytoremediation}

The application of phytoremediation is a new method of cleaning brownfields in North American over the past 20 years. ${ }^{3}$ Phytoremediation is the application of plants to remove, downgrade or alleviate contaminants from water or soil. Plants are selected for application according to their ability to treat present contaminants and thrive in the given geographic location. This is the benefit of phytoremediation: it contains the ability to adapt to a number of climates and represent the natural vegetation of a specific place. Unlike other methods of remediation that dispose or conceal contaminated soil, phytoremediation is a slow but effective process that directly addresses a hazardous environment and alters it to become habitable.

\section{Contaminants}

The Canadian government defines contaminants in A Federal Approach to Contaminated Sites (1999) as "any physical, chemical, biological or radiological substance in air, soil or water that has an adverse effect. Any chemical substance whose concentration exceeds background concentrations or which is not naturally occurring in the environment." ${ }^{4}$ These contaminants are unnatural chemicals that are physically attached to soil particles or exist in the spaces between soil particles. ${ }^{5}$ The primary concern for the presence of contaminants in brownfield sites is the potentially hazardous effects on humans once the site has been altered for public occupancy. In the situation of Stelco, the most common contaminants are Polyaromatic Hydrocarbons, or PAH for short. Polyaromatic Hydrocarbons include over 100 different chemicals, formed during the incomplete burning of organic substances. ${ }^{6}$ Emissions from coal burning, coke ovens, and electric ark furnaces would be just a few sources for this contamination in a steel factory. 


\section{Process of Phytoremediation}

Plants will react to different contaminants in a variety of ways in addition to the affects of climate and soil condition. These reactions can occur singularity or as a combination of absorbing, transforming or holding the contaminants. For the contaminants present at Stelco's site four process of phytoremediation occur in several plants species. Processes of phytoremediation for PAH contaminants on heavy industry sites. ${ }^{7}$

\section{PHYTOEXTRACTION}

Plants absorb contaminates into their roots and store them in large quantities within their stem and leaves, contaminates are not released into the air.

\section{PHYTODEGRADATION}

Plants break down contaminants through photosynthesis, the pollutants can be degraded into a less toxic state and integrated into the plant or remain in the soil.

\section{PHYTOVOLATILIZATION}

Plants absorb and release containments into the atmosphere following a process of photosynthesis and transpiration which degrades the contaminant into a less toxic state.

\section{RHIZOFILTRATION}

Plants can also assist in the degradation of contaminates. In this process, microbes within the soil will weaken or abolish contaminants but are dependent on the root environment provided by the plant. 


\title{
Tree Types
}

Due to the reactive nature of plant remediation, each design must choose plants according to its geographic location, and contaminants of concern. Specifically for Stelco, the following trees were chosen according to their capability to treat the contaminants on the Hamilton site, and their adaptability to future urbanspecific applications. The following trees will slowly remediate the land, while producing viable trees for distribution across Hamilton every 5 years. Once the soil has completed the cleaning process, other tree types can be integrated into the growing cycle for different applications, for example a Christmas tree farm.

\section{PINE TREE}

\author{
PAH : Polyaromatics Hydrocarbons \\ PHYTOEXTRACTION \\ PHYTOVOLATILIZATION \\ Fast-growing, Pine is commonly used in plantation \\ forestry, so is easy to source for mass plantings. \\ URBAN APPLICATION: \\ Used in seasonal plantings for December holiday \\ season. Private application as Christmas tree, \\ once brownfield is remediated.
}



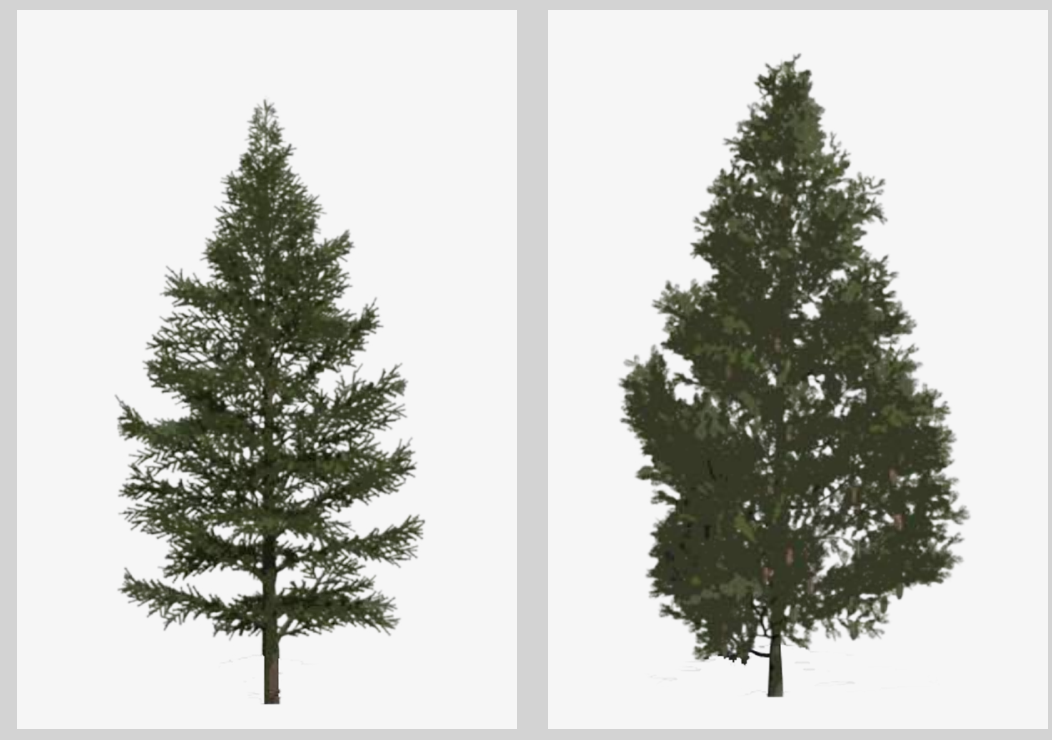

\section{Fraser + Balsam Fur}

\section{Blue + White Spruce}
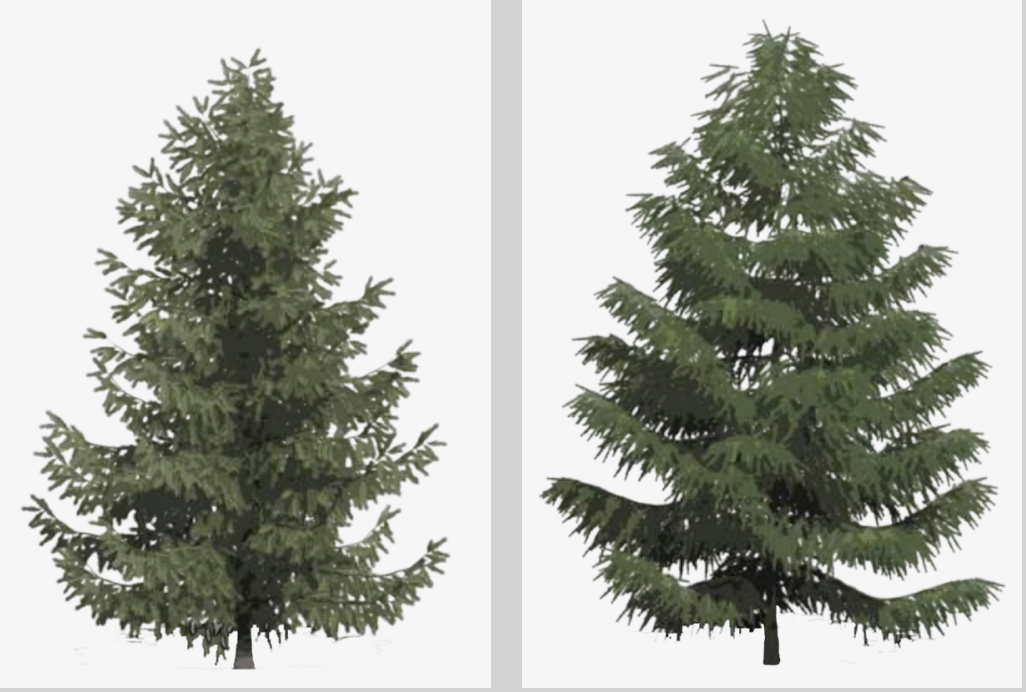

White + Scots Pine
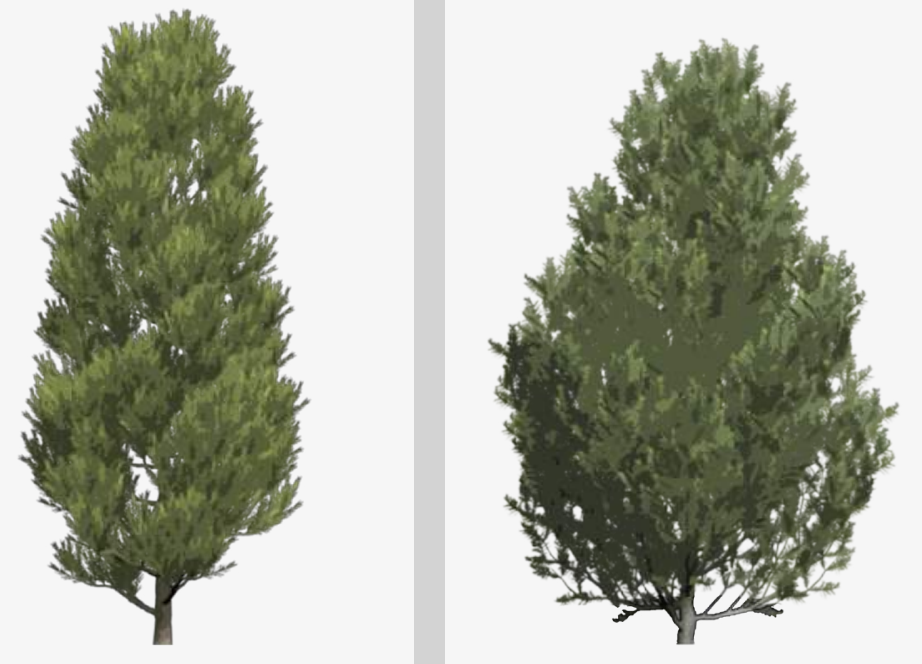


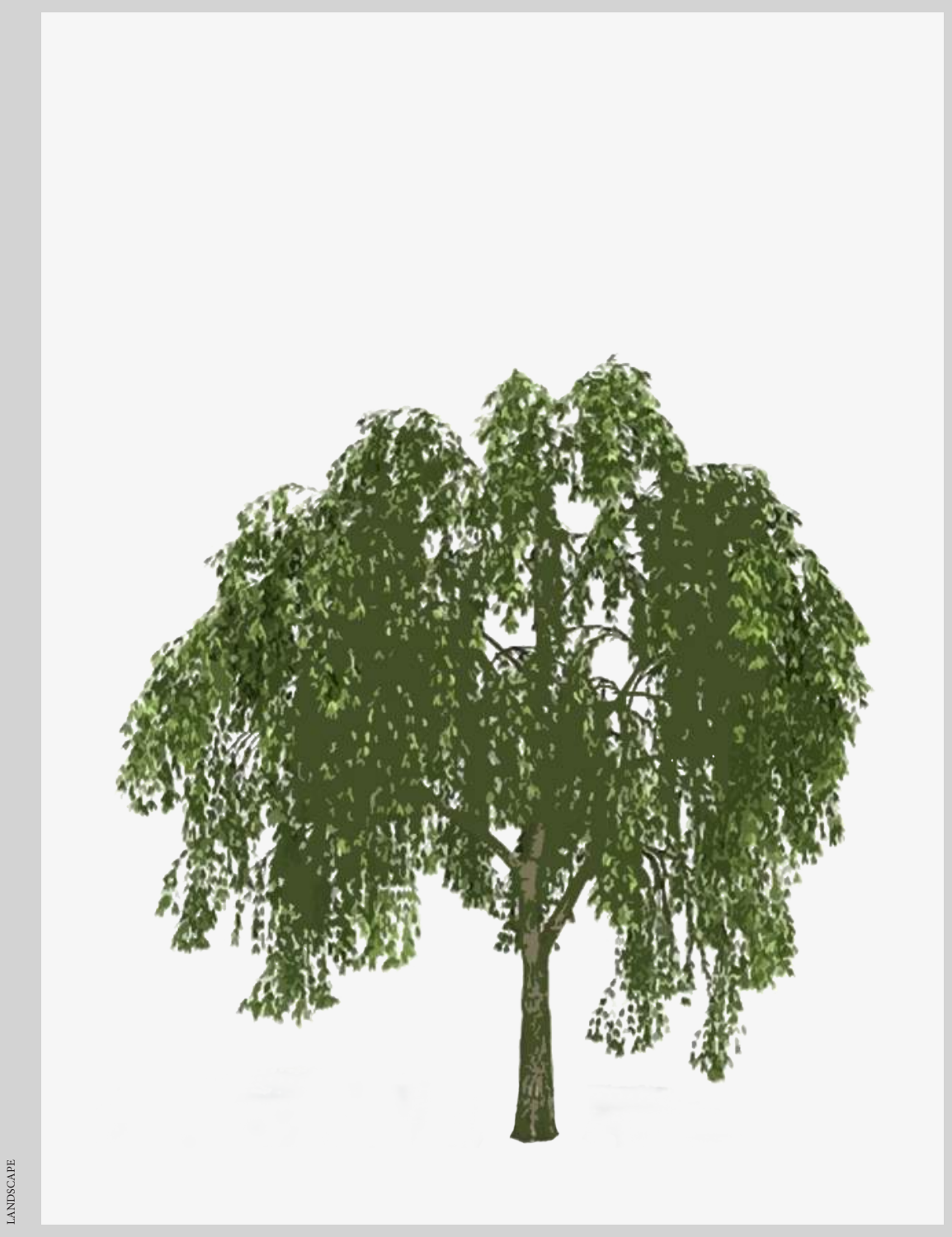

106

\section{WILLOW TREE}

PAH : Polyaromatics Hydrocarbons

PHYTOEXTRACTION

\section{PHYTOVOLATILIZATION}

Easy to grow and broadly effective.

URBAN APPLICATION:

Used in waterfront landscapes, wetlands and marches.

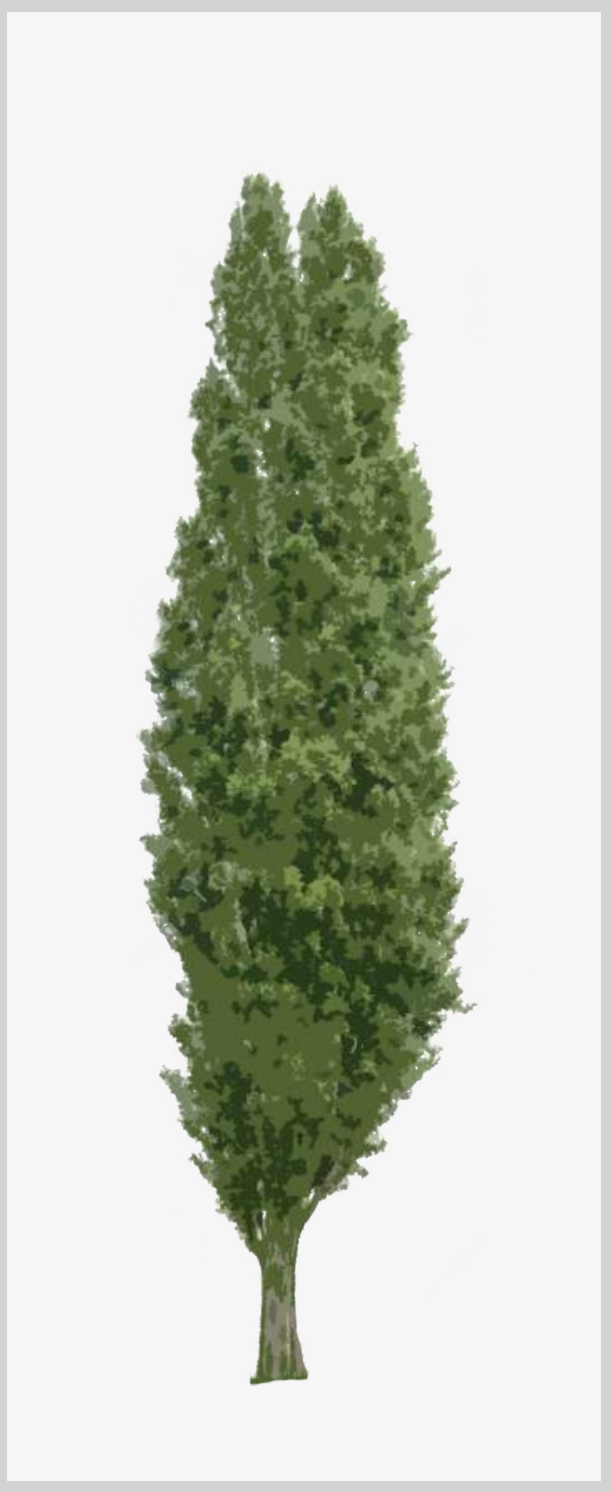

\section{POPLAR TREE}

PAH : Polyaromatics Hydrocarbons

PHYTOEXTRACTION

PHYTOVOLATILIZATION

PHYTODEGRADATION

RHIZODEGRADATION

\section{URBAN APPLICATION:}

Used in waterfront landscapes, beaches and marches. 


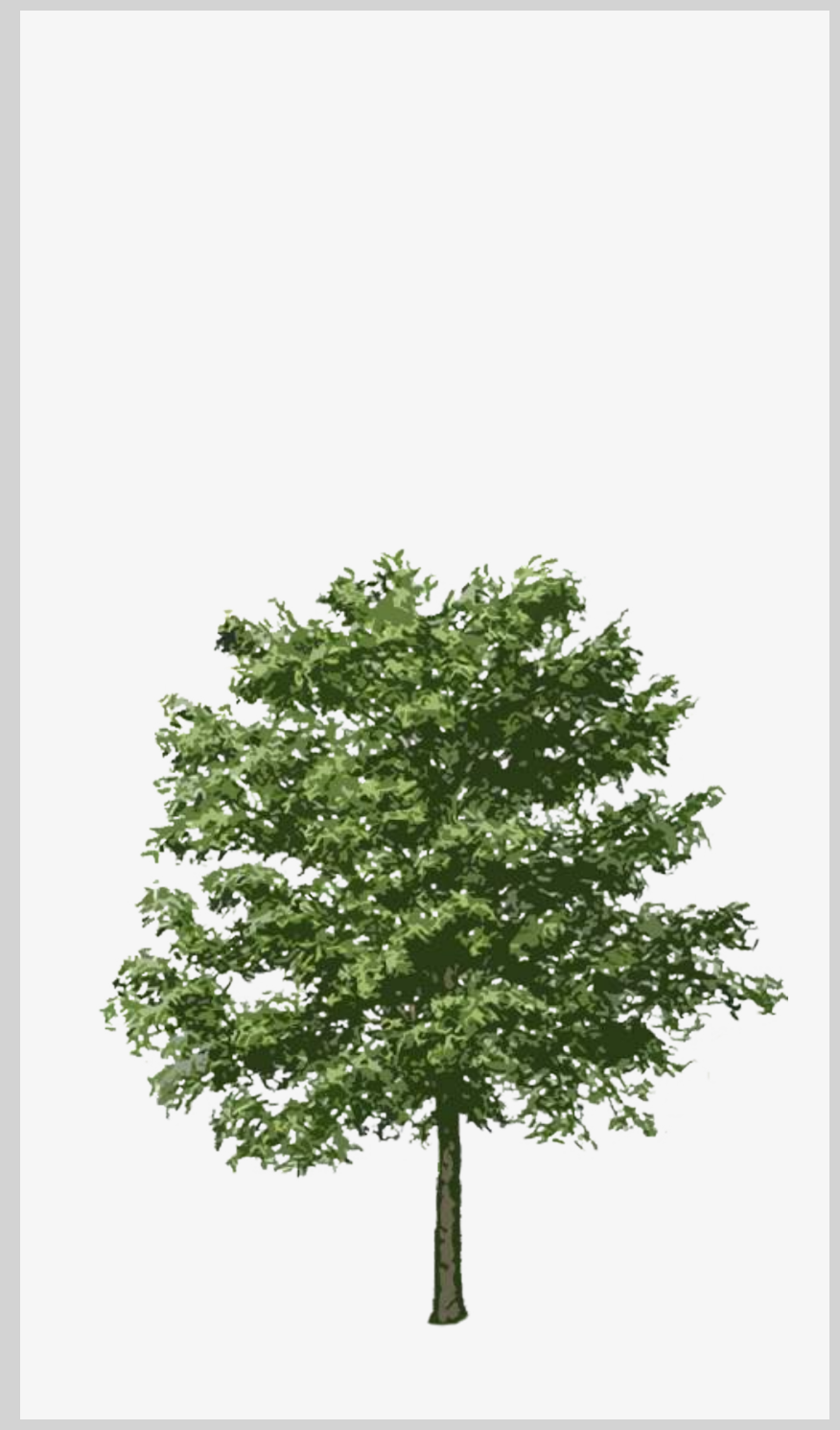

\section{LOCUST TREE}

PAH : Polyaromatics Hydrocarbons

PHYTOVOLATILIZATION

Nitrogen-fixing Locust is a scrappy pioneer species that can survive marginal sites and soils.

\section{URBAN APPLICATION:}

Very popular urban tree used in streetscapes, large landscapes, community parks and neighbourhoods.

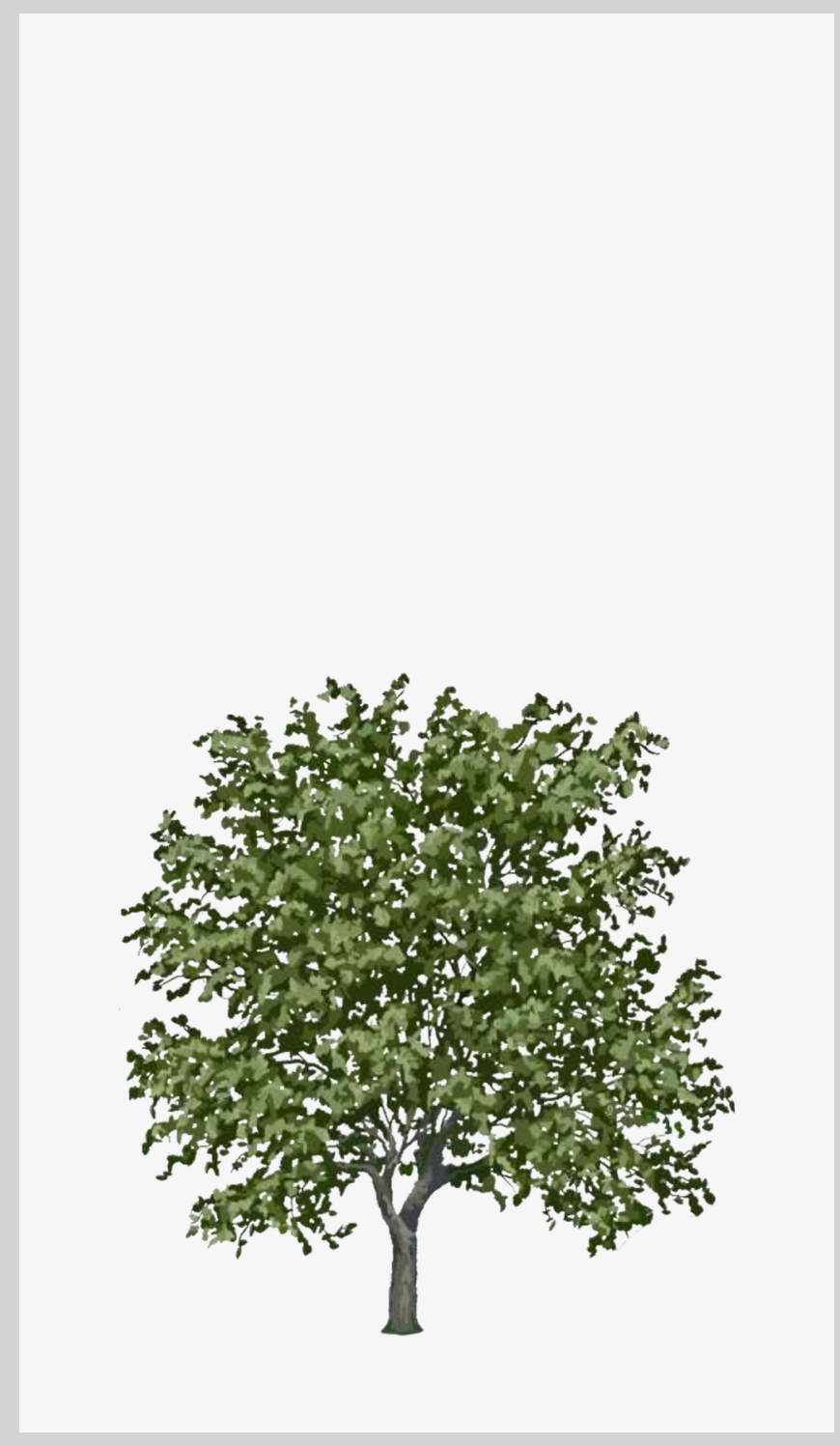

\section{MULBERRY TREE}

PAH : Polyaromatics Hydrocarbons

\section{PHYTOVOLATILIZATION}

\section{RHIZODEGRADATION}

Mulberry's support diverse fungal and bacterial communities in soil that degrade organic contaminants.

\section{URBAN APPLICATION:}

Mostly used in public parks and a few more remote residential neighbourhoods. 



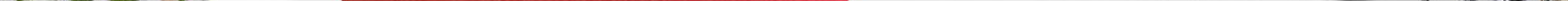



1 David Proulx, Pardon My Lunch Bucket (Hamilton: The Corporation of the City of Hamilton, 1970), n.p.

2 Ibid.

3 JG Isebrands and DF Karnosky, Environmental benefits of poplar culture. In: Dickmann DI, Isebrands JG, Eckenwalder JE, J. R (eds) Poplar Culture in North America. (Ottawa: CRC Press) n.p.

4 Dillon Consulting Limited, "A Federal Approach to Contaminated Sites.” Federal Contaminated Sites (1999): 1. Accessed March 15, 2015.

http://www.federalcontaminatedsites.gc.ca/8DF3AC07-5A7D-483F-B263-6DE03104319A/fa-af-eng.pdf.

5 “Soil Contamination,” EPA, accessed March 15, 2015, http://www.epa.gov/superfund/students/wastsite/soilspil.htm.

6 Rebekah Dye, Andrea Parker, Kaja Kühl, and Jay Tsai, "Brownfields and Greenfields.” Youarethecity(2011): 9. Accessed March 15, 2015.

http://www.youarethecity.com/work/brownfields-to-greenfields/.

7 Ibid, 14. 

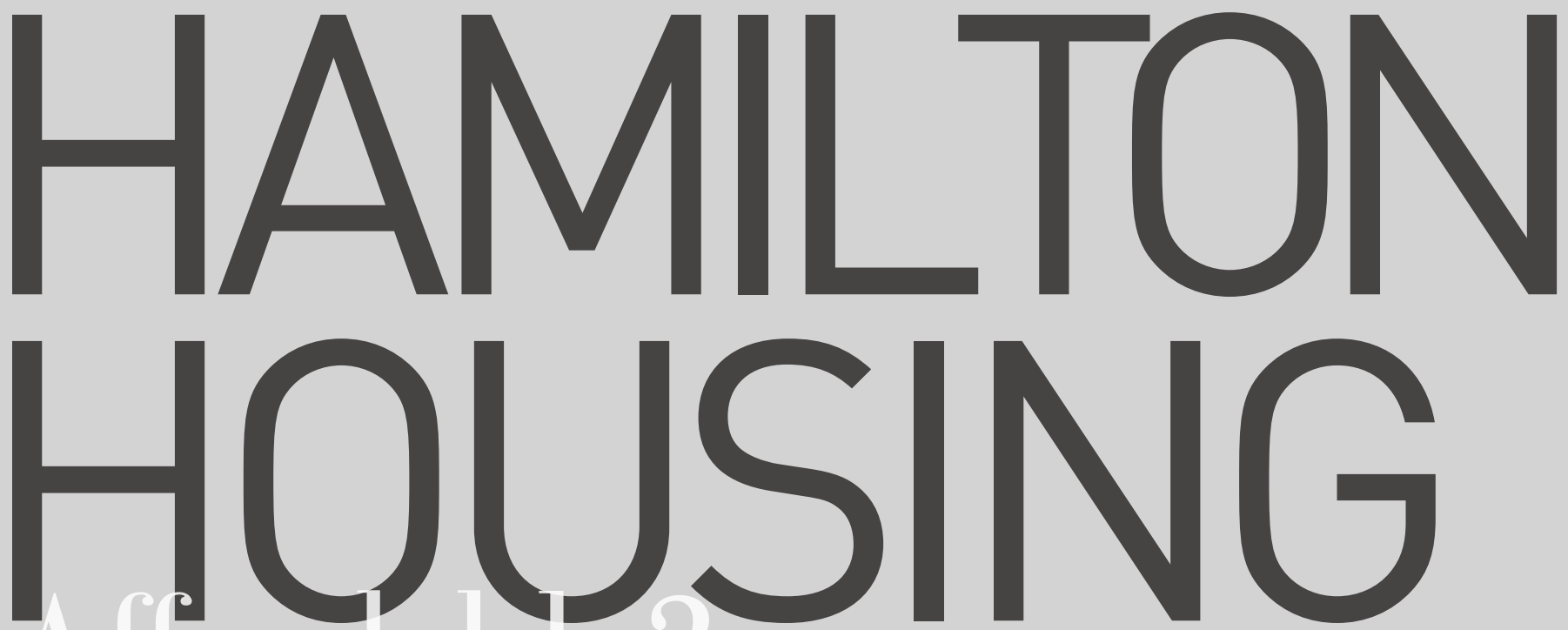

112 


\section{Places to Grow Plan}

Published in 2005 by the province of

Ontario, Hamilton's Places to Grow Plan is

a 30-year forecast of growth from 2001 to

2031. The plan includes strategies to guide development for population, employment and housing growth. Over the 30-year forecast, 80,000 households were estimated to lead to a population growth of 150,000 people. ${ }^{1}$ However, 10 years later, the 2011 Census Canada reported over 280,000 households in Hamilton, more than a 100,000 dwelling increase and 20 years earlier than the Places to Grow Plan prediction. In its plan, Hamilton provided basic growth strategies to support the new housing market. This included a limit to urban boundary expansion, downtown focused intensification, and appropriately distributed development that would support a nodes and corridor urban plan. ${ }^{2}$ In reality according to census data, a majority of the new homes built in the last decade have been of suburban types, thus applying pressure to the urban boundary of the city. Along with the new neighbourhoods, oversized commercial centres pushed people further and further away from the downtown. Hamilton's recent history has seen some improvements to its downtown. Street improvements, bicycle lanes, small commercial business and focus on public transportation have supported their desire of downtown intensification. For private development, the reality is that suburbanization produces results sooner and with less difficulty than urban renewal. New suburban neighbourhoods have proven in the past to be successful in providing large quantities of housing; however these have also arguably been a primary factor in the degradation of urban centres. With this unprecedented growth, approval for rapid residential development was lenient in order to fulfill the new housing demand. While this development method was not initially planned, it will continue to expand the urban boundary unless an alternative approach is enforced and supported in the private sector. Other Canadian cities have approached housing intensification in a variety of ways. Examples include laneway, infill and condominium construction in Vancouver, Toronto and Ottawa respectively. 


\section{PREDICTED GROWTH}

YEAR POPULATION \# OF HOUSEHOLDS

$2001 \quad 510000 \quad 190000$

$2011540000 \quad 210000$

$2021 \quad 590000 \quad 240000$

$2031 \quad 660000 \quad 270000$

change $\quad 150000 \quad 80000$

ACTUAL GROWTH

YEAR POPULATION \# OF HOUSEHOLDS

$2001 \quad 510000 \quad 190000$

$2011519949 \quad 282185$

$2014 \quad 551785 \quad 292755$

change $\quad 41785 \quad 102755$ 


\section{Hamilton Growth Strategies}

Although to some degree every developing city will utilize a variety of housing strategies, Hamilton as a rust belt city has unique urban characteristics unlike most Canadian cities. Hamilton's industrial sites are threatened with vacancy due to the shift from a national market to a global economy. While these sites hold historical significance, left vacant they are of no value to the development of Hamilton unless remediated and altered for a new use. Adapting brownfield sites has been a relatively new method of urban renewal in Canadian rust belt cities. Using this device for future development, large quantities of housing can be implemented within the urban boundary. These sites hold significant value to Hamilton's future development due to their abundance, central location and capacity to hold a variety of programs. For these future

116 mixed-use projects, housing should

\section{Growth Strategies}
(1) NO URBAN
BOUNDARY
EXPANSION
(2) APPROPRIATELY
DISTRIBUTED
DEVELOPMENT
(3) DOWNTOWN FOCUS
(NODES \& CORRIDORS)

continue to be a primary concern.

The next section on Hamilton's housing market will explore and compare the affordability of owner and rental housing for Hamilton residents and the Great Toronto Area. The goal of this research is to determine the housing needed by Hamilton residents (and not just the houses that are sell in the suburbs). 


\section{Average Hamilton Income}

In the 2011 Census Canada data, Hamilton's average annual income for households with two working adults was just shy of $\$ 90,000$. The average lone-parent family will earn less than half the income of a two-parent family and residents living alone will earn less than a third, $\$ 41,000$ and $\$ 25,000$ respectively). By the end of 2014, the average house price across all types was just shy of $\$ 330,000$. An annual income of $\$ 60,000$ is required to afford the average Hamilton house (affordable for households with two incomes); however it is far above the income of a single parent or individual living alone. Following the common definition of affordable housing as $30 \%$ of an individual's annual income, approximately $40 \%$ of local residents are being priced out of ownership within Hamilton's existing and new build housing market.
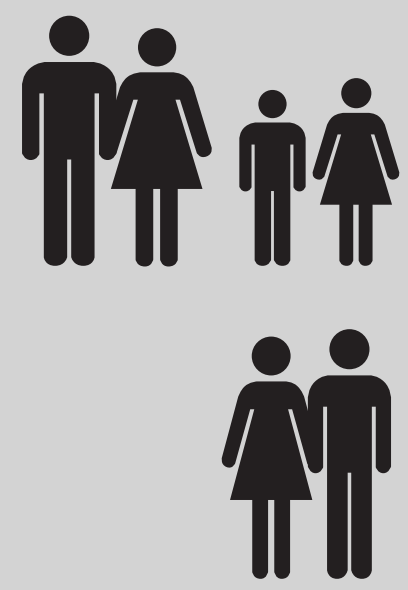

$\$ 80400$ ALL FAMILY TYPES AVERAGE INCOME

$\$ 89190$

COUPLE FAMILIES TWO INCOMES
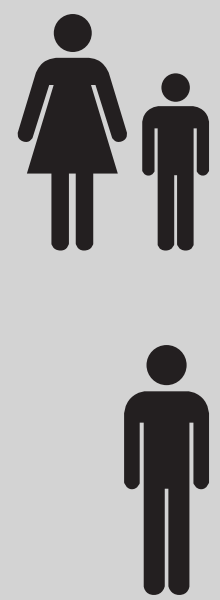

$\$ 41170$ LONE-PARENT FAMILIES SINGLE INCOME

\section{$\$ 25000$ \\ NOT IN A CENSUS FAMILY SINGLE INCOME - NO CHILDREN}




\section{Hamilton's Housing Market}

AVERAGE HOUSE PRICE

$\$ 266567$

$\$ 307304$

$\$ 329044$

$\$ 412000$

$\$ 538000$

$\$ 334537$
2010

2013

2014 APPROXTIMATE

2014 EXISTING SINGLE-DETACHED

2014 NEW SINGLE-DETACHED
AVERAGE PRIVATE RENT PRICES

\$ 537 /MONTH BACHELOR

\$ 687 /MONTH 1BEDROOM

$\$ 814$ /MONTH 2BEDROOM

\$ 980 /MONTH 3+BEDROOM

\$ 747 /MONTH AVERAGE

\section{OWNERSHIP}

In November 2014, among all Census Metropolitan Areas in Canada ${ }^{3}$, Hamilton recorded the largest increase in monthly new home prices. ${ }^{4}$ The average single-detached house price for new construction rose to almost $\$ 540,000$ and the average existing house price to $\$ 412,000$ by the end of $2014 .{ }^{5}$ In a four-year span (from 2010 to 2014) the average housing market has grown one and half times. This market growth is only sustainable if the average income increases at a similar rate. In 2014, the Canadian Mortgage and Housing Corporation projected that the income required to buy a home in Hamilton will continue to edge closer to the actual income for the average Hamilton household. ${ }^{6}$ 


\section{INDIVIDUAL SINGLE PARENT}

$\$ 9.81 / \mathrm{hr}$

$\$ 10.25 / \mathrm{hr}$

$\$ 6.08 / \mathrm{hr}$

$\$ 3.43 / \mathrm{hr}$
$\$ 15.16 / \mathrm{hr}$

$\$ 10.25 / \mathrm{hr}$

$\$ 13.96 / \mathrm{hr}$

$\$ 9.85 / \mathrm{hr}$
HOURLY WAGE REQUIRED TO

AFFORD AN APARTMENT.

ACTUAL MINIMUM WAGE

HOURLY WAGE FOR PERSON WITH GOVERNMENT SOCIAL ASSISTANCE.

HOURLY WAGE FOR PERSON ON OW (Ontario Works)

\section{RENTAL}

For many Hamiltonians owning a house is not affordable. Therefore, then must rent.

Considering that the average monthly rent (across all types of housing) is approximately

$\$ 750$, an individual requires a yearly income of $\$ 29,300$ to afford their monthly expenses. ${ }^{7}$

In reality $21 \%$ of Hamilton's renter households pay more than $50 \%$ of their monthly

income on rent. ${ }^{8}$ This kind of urban poverty suggests a severe lack in sufficient jobs and a

growing gap between the average income and the average price of rental units in Hamilton.

Minimal housing options for low-income families force proficient working citizens to

seek government assistance and a strain on Hamilton's social housing programs. While

Hamilton's social housing is struggling to provide housing and assistance for all residents, the vacancy rate in private rentals reached 4.1 percent in 2012, exceeding a healthy rate between two and three percent. ${ }^{9}$ This vacancy rate comes full circle, affecting the building owners that depend on their rental properties to provide an income, a consequence due to the lack of affordable housing in Hamilton's rental housing market. Rental units continue to rise in price across all bedroom types, increasing by a minimum of three percent between 2012 and 2013. ${ }^{10}$ A comparison between individual families and single-parent families with the price of the appropriately sized unit highlights the required hourly income for afford adequate housing with and without government assisted programs. 
HAMILTON

2009 AVERAGE HOUSE

2013 AVERAGE HOUSE

PERCENT INCREASE

5\% DOWNPAYMENT

MORTGAGE

MONTHLY MORTGAGE

MONTHLY HOUSING COSTS

MEDIAN FAMILY INCOME

YEARLY REQUIRED INCOME
\$ 248087

$\$ 307304$

$23.9 \%$

$\$ 15365$

\$ 291939

$\$ 1382$

$\$ 1425$

$\$ 77497$

$\$ 57000$
TORONTO

$\$ 395460$

$\$ 23007$

$32.25 \%$

$\$ 26150$

$\$ 496857$

$\$ 2351$

$\$ 2425$

$\$ 72890$

$\$ 97000$ 


\section{Hamilton vs. Toronto}

Propelling the increase in Hamilton's

housing prices is the influx of out-of-

town buyers. Compared to the rest of the

Greater Toronto Area housing markets,

Hamilton is still more affordable. Buyers

from less affordable municipalities will

continue to build a relatively stable local

market for Hamilton sellers, despite

creating more competition for local

buyers. ${ }^{11}$ Housing price gap between

Toronto and Hamilton listings grew from

$36 \%$ in the middle of 2014 to $43 \%$ at

the end of 2014, attracting prospective

homebuyers to a more affordable market. ${ }^{12}$

The widening house gap between

Toronto and Hamilton markets forced

first time homebuyers between 25 and

44 commuting to work to afford a family

home. ${ }^{13}$ Fewer new listings on the existing

home market have encouraged some

buyers to meet their needs in the new

home market. 


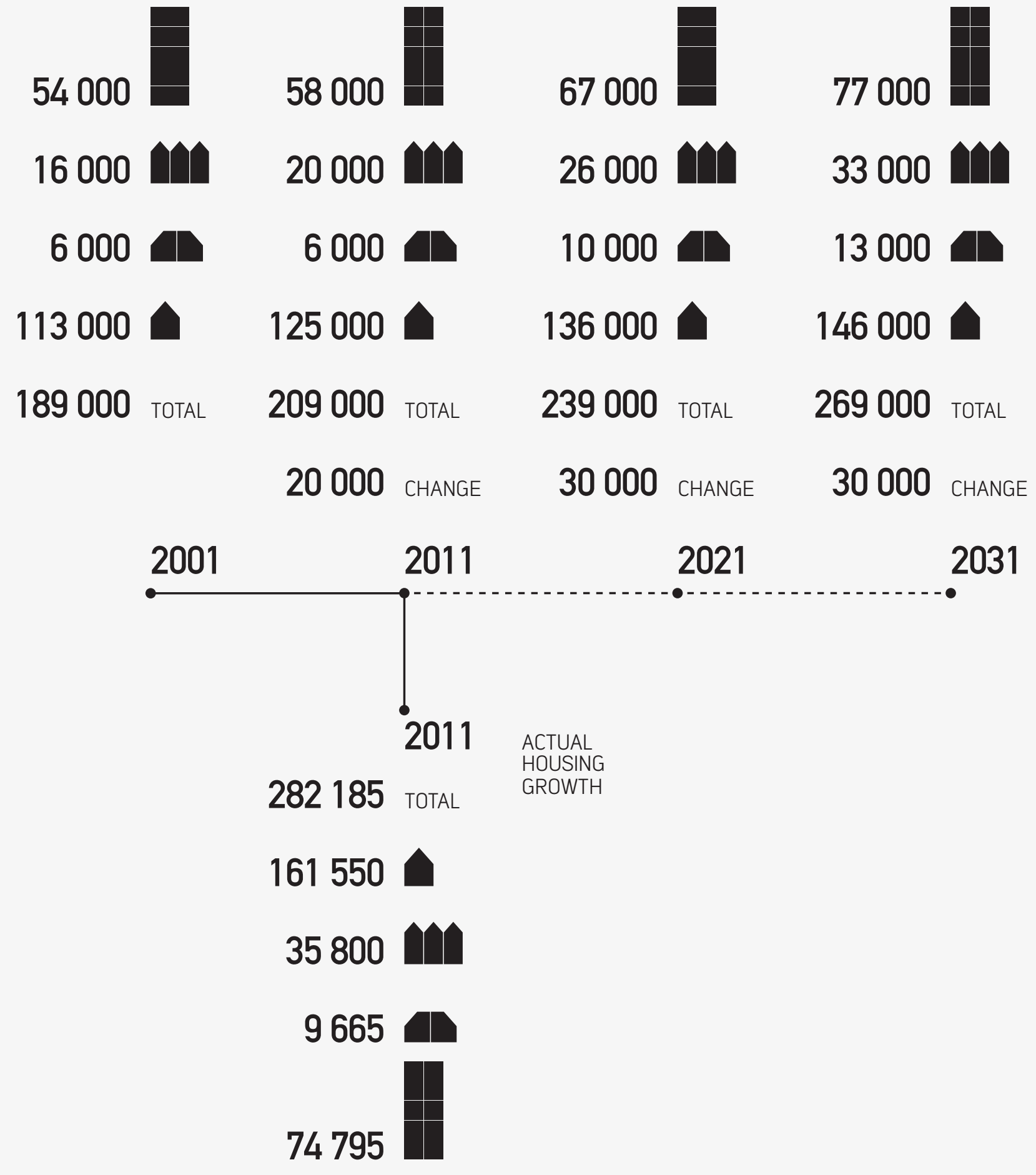




\section{Hamilton Housing Typologies}

Hamilton's Places to Grow Plan also

breaks down the purposed structural

typology to achieve the 80000 household

growth. When compared to the 2011

census data the current construction

market shows a high public interest in

single-detached and townhouses over

semi-detached houses and apartments. ${ }^{14}$

Given Hamilton's recent urban renewal of its downtown via the integration of small local businesses, including galleries, coffee shops and restaurants, in addition to the lack of interest in high-rise developments, suggests that the area's density has not reach a crisis.
A recent increase in townhouse construction in 2014 was due to a tight resale market.

Many homebuyers in search of affordable housing were encouraged to buy new town homes on the periphery of urban Hamilton, as the most affordable housing type in the low-rise category. This is particularly evident in a new housing type emerging in Hamilton's new suburbs (approximately 25 minutes from downtown): a back-to-back, three-storey townhouse. It includes the basic qualities that a traditional suburban house offers: quiet neighbourhood, new construction, parking, and street access while providing a low maintenance level. These are the qualities Hamilton residents are looking for and they should be achieved in houses built and sold at affordable rates. 


\section{“Affordable" Housing}

Affordable is a term commonly used

in current marketing strategies for

suburban and condominium developers.

"Affordable" describes something that

is perceived as more valuable than the

offered sale price; or it is associated with

questions of one's income level and the

ability to afford a specific lifestyle. Rarely

does it consider the product's economic

accessibility. Hamilton's definition of

affordable housing, as outline in the

Housing \& Homeless Action Plan, is

housing that costs $30 \%$ or less of the

gross household income for households

with low to moderate income. ${ }^{15}$ The

phrase "affordable housing" should be

accessible to the largest economic bracket.

In Hamilton, this value would be a yearly

income of $\$ 25,000$. A mortgage calculated

with an annual income of $\$ 25,000$ would

make it affordable and accessible to the

124 greatest number of Hamilton residents. 


\section{Hamilton's Housing \& Homeless Action Plan}

"Everyone has a home...Home is the foundation." This statement defines Hamilton's Housing \& Homeless Action Plan released in 2013. It addresses issues in providing adequate housing for citizens in need. The city believes that housing is a fundamental need and proves to be beneficial for a thriving economy and vibrant social community. ${ }^{16}$ It is the foundation for individuals to build a life, nurture their family and engage in the community. Although the city currently provides housing assistance there are still areas of social housing that require improvement. The Action Plan reveals that approximately 5,400 households are on the wait list for social housing in addition to the 5,650 individual men, women and children that sleep in emergency shelters yearly. ${ }^{17}$

\section{Rent-Geared-to-Income}

Rent-geared-to-income (RGI) housing is a form of subsidized housing provided by the Ontario Government. The rent is based directly on the tenant's income, usually $30 \%$ of the gross monthly household income. If you receive social assistance such as Ontario Disability Support Program (ODSP) or Ontario Works (OW), the rent charges are based on the rent benefit set by the Ontario government, (rather than 30 per cent of the gross monthly income). ${ }^{18}$ In 2006, the RGI waitlist included 4,375 active applicants; this value grew to 5,406 in 2011 and continues to grow with the increase in Hamilton's housing market. ${ }^{19}$ The average waiting time for active applicants is 19 months; this can be drastically shortened or lengthened depending on the applicant, (male individuals wait the longest while females with children will receive housing almost immediately). There are obvious issues with this program, given the extensive waiting list. Rent-geared-to-income cannot provide adequate housing for all citizens in need. Moreover, it often fosters long-term dependency with no clear goal to integrate residents back into the housing market. 


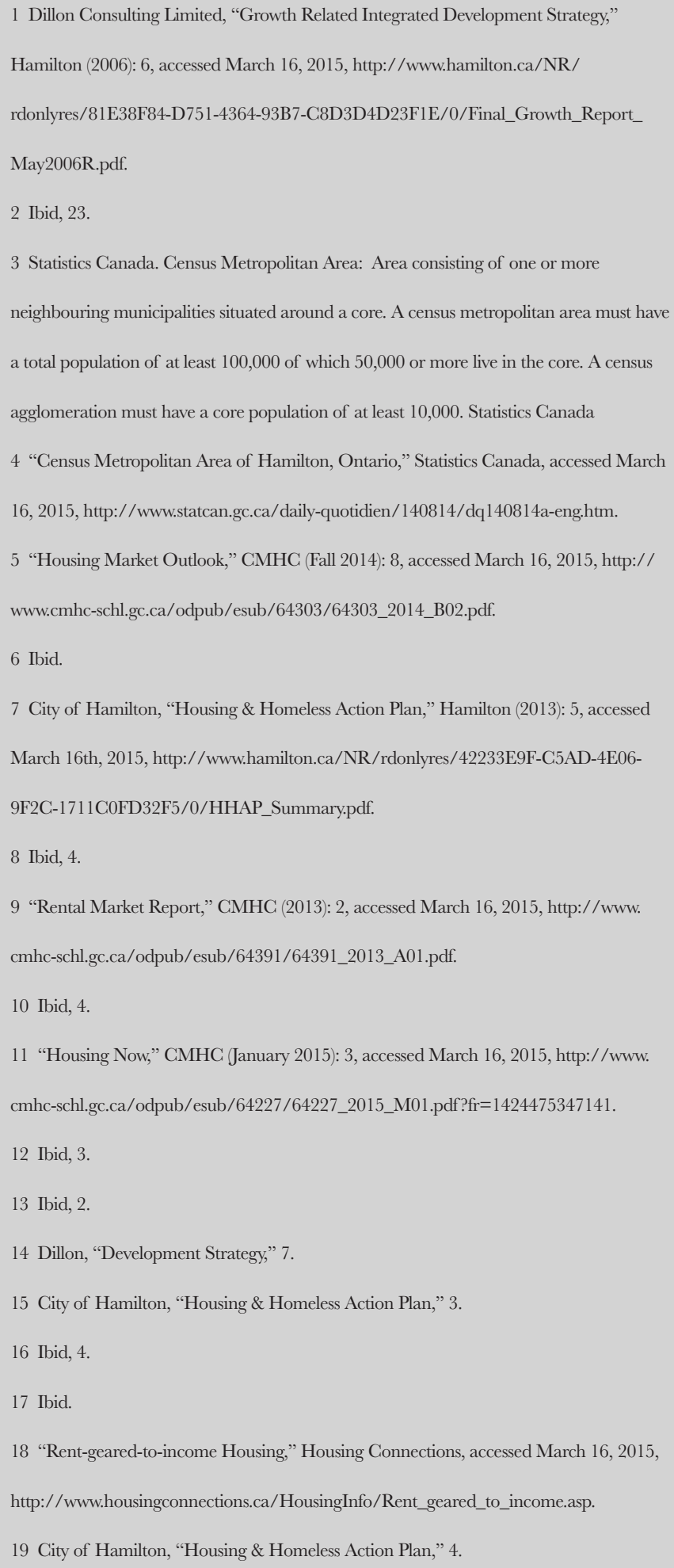




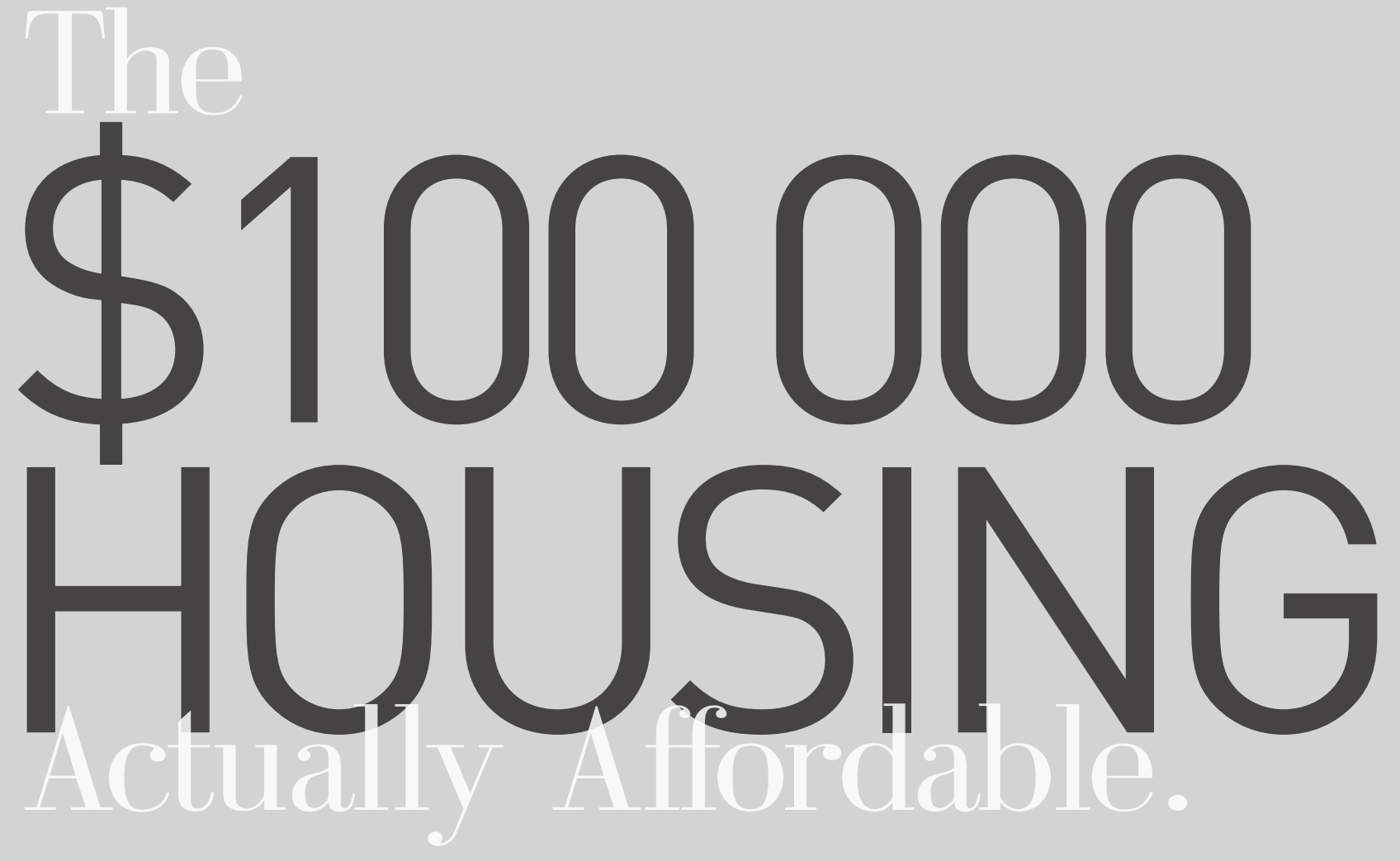

128 


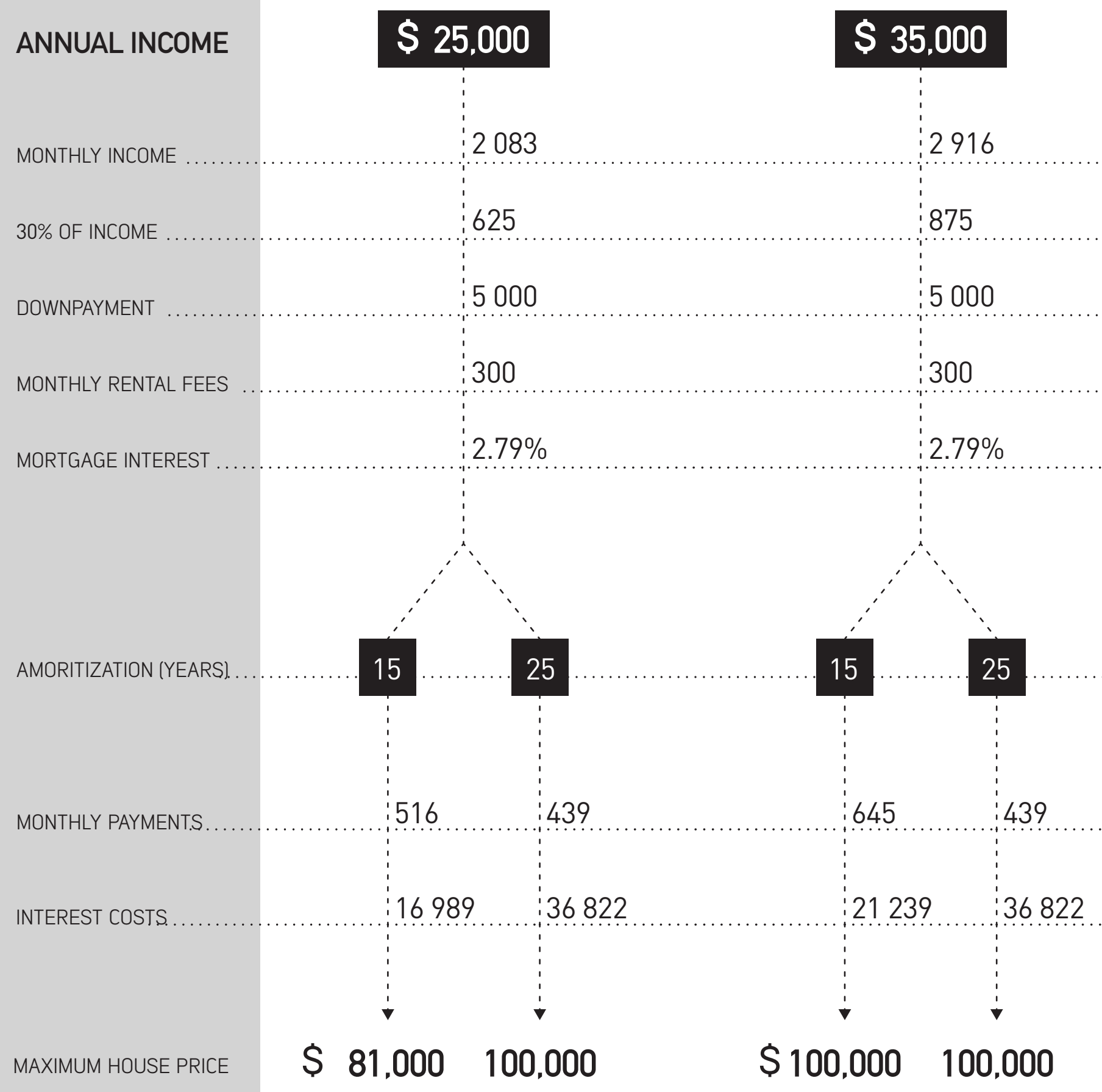




\section{$\$ 100,000$ House}

The $\$ 100,000$ house is a new typology of affordable housing that draws upon the favourable characteristics of condominiums, apartments and coop housing developments. The occupant owns their housing unit like a condominium; however in addition to monthly mortgage payments the occupant will pay $\$ 300$ per-month for utilities, storage, laundry and lot rent. This will secure their housing spot within the development and provide the connection for plumbing and electricity. The system is similar to an apartment, where multiple units share common utilities.

\section{Mortgage Affordability}

Unit price is based on the three incentives provided by the Canadian Mortgage and Housing Corporation and an annual income of $\$ 25,000$, the lowest income quintile and the average income for single individuals in Hamilton. With an annual income of $\$ 25,000$ an individual can afford a mortgage of $\$ 100,000$ over 25 years with monthly payments of $\$ 439.41$. This is approximately $\$ 185$ lower than the affordable month payment of $\$ 625$ according to Hamilton's definition of affordable housing ( $30 \%$ of annual income). 


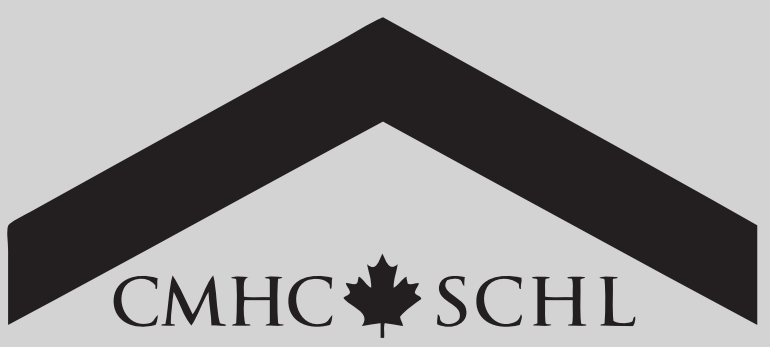

\section{\$5 000 FIRST-TIME HOME BUYERS TAX CREDIT}

\section{5\% DOWNPAYMENT}

\section{FORGIVABLE LOAN}

\section{CMHC Incentives}

It's CMHC mission statement commentary reads:

Canada Mortgage and Housing Corporation (CMHG) has been Canada's national housing agency for more than 65 years. Together with other housing stakeholders, we help ensure that the Canadian housing system remains one of the best in the world. We are committed to helping Canadians access a wide choice of quality, environmentally sustainable and affordable housing solutions that will continue to create vibrant and healthy communities and cities across the country. ${ }^{1}$

CMHC provides a number of incentives for first-time homebuyers and individuals with a low income. These incentives include a $\$ 5,000$ tax credit, a 5\% down payment, and forgivable loans. A house designed around this set of incentives for low-income families would make ownership possible for the large majority that are currently priced out of the Hamilton market. 


\section{Ownership-Geared-to-Income}

Ownership-geared-to-income (OGI) is a suggested service for individuals that make less than $\$ 25,000$ annually. Like RGI the provincial government would subsidize the initial costs in purchasing a $\$ 100,000$ home. This potential service could provide better interest rates, financial help with a down payment or month support for utilities or mortgage payments. The difference with this program is permanency: the future goal of financial assistance in ownership is to provide all citizens in need with a permanent house and equity to live a financially stable life.

\section{Neighbourhood Commitee}

The role of the Neighbourhood Housing Board after development completion is crucial to the success of the neighbourhood as a whole, and specifically its endeavour to provide continual affordable housing well into the future. Like many coop housing boards, the housing committee will manage daily and long-term building maintenance and regulate conflicts and communication on behalf of all residents within the site or with city hall. Unique to this social system of housing, the committee would provide the support services suggested by Hamilton's Official Plan via the governing of the initial sale of all units and provide financial guidance for first-time homebuyers. Moreover, the committee's purpose is to regulate and market the resale of any unit within the site. The resale value for social housing units will increase in correlation with the average low-income in Hamilton to ensure units remain affordable for many people. The unit resale price should never decrease in value to protect the investment made by the individual owner. However, if the average annual income drops dramatically below the minimum income requirement to afford a $\$ 95.000$ house mortgage, previous owners will be subsidised by the government to cover any lose of investment. This is to say that if the average individual income for Hamilton residents not in a census family dips below $\$ 25,000$ annually so to will the resale price of the unit, and therefore the city will provide the difference of investment for the first owner. Most likely, the average income will increase and the value of each housing unit will too increase at the same affordable rate. For example, if the annual income of $\$ 25,000$ increases by $10 \%$ to $\$ 27,500$, the value of the $\$ 100,000$ unit will increase to $\$ 110,000$. 


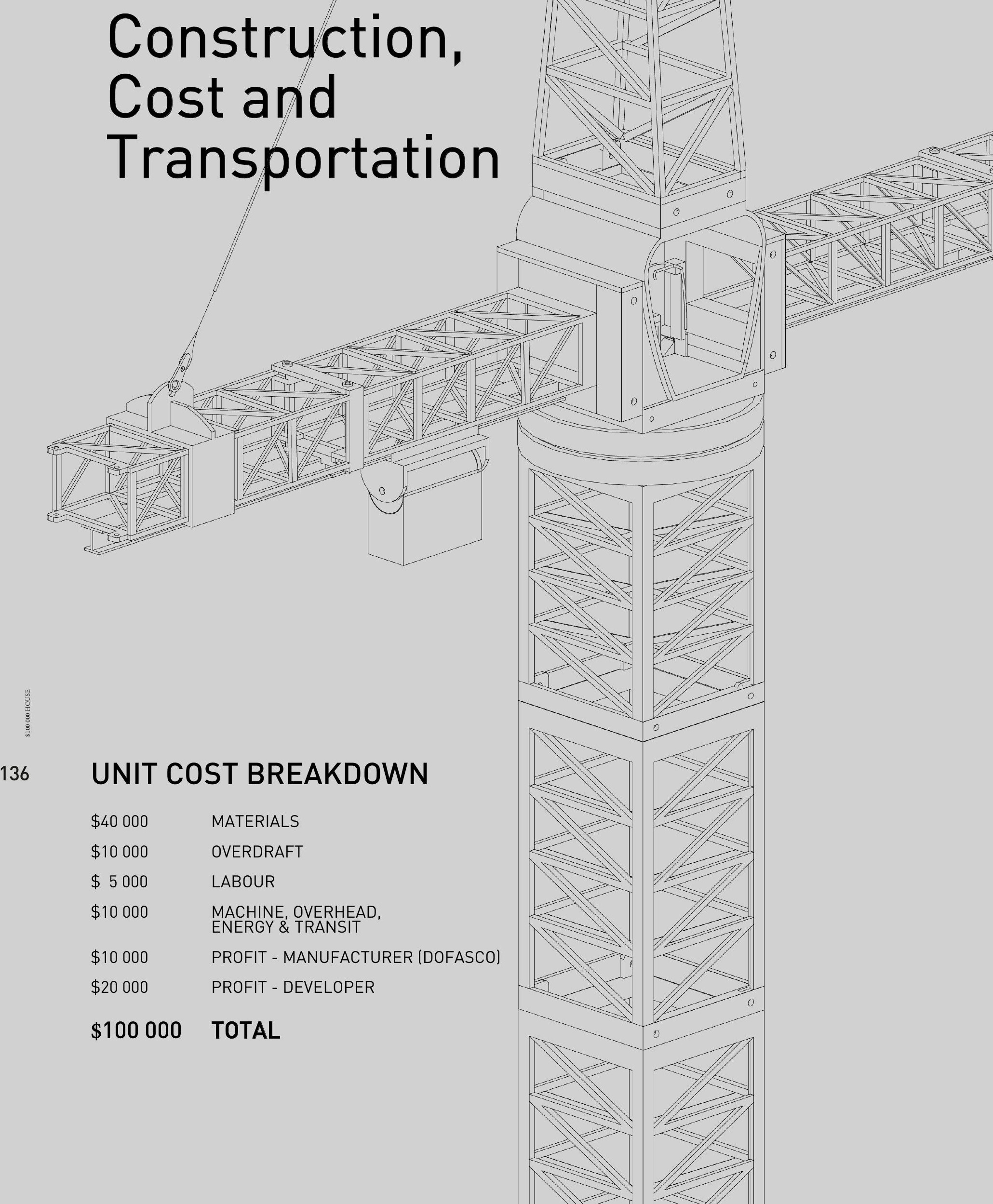




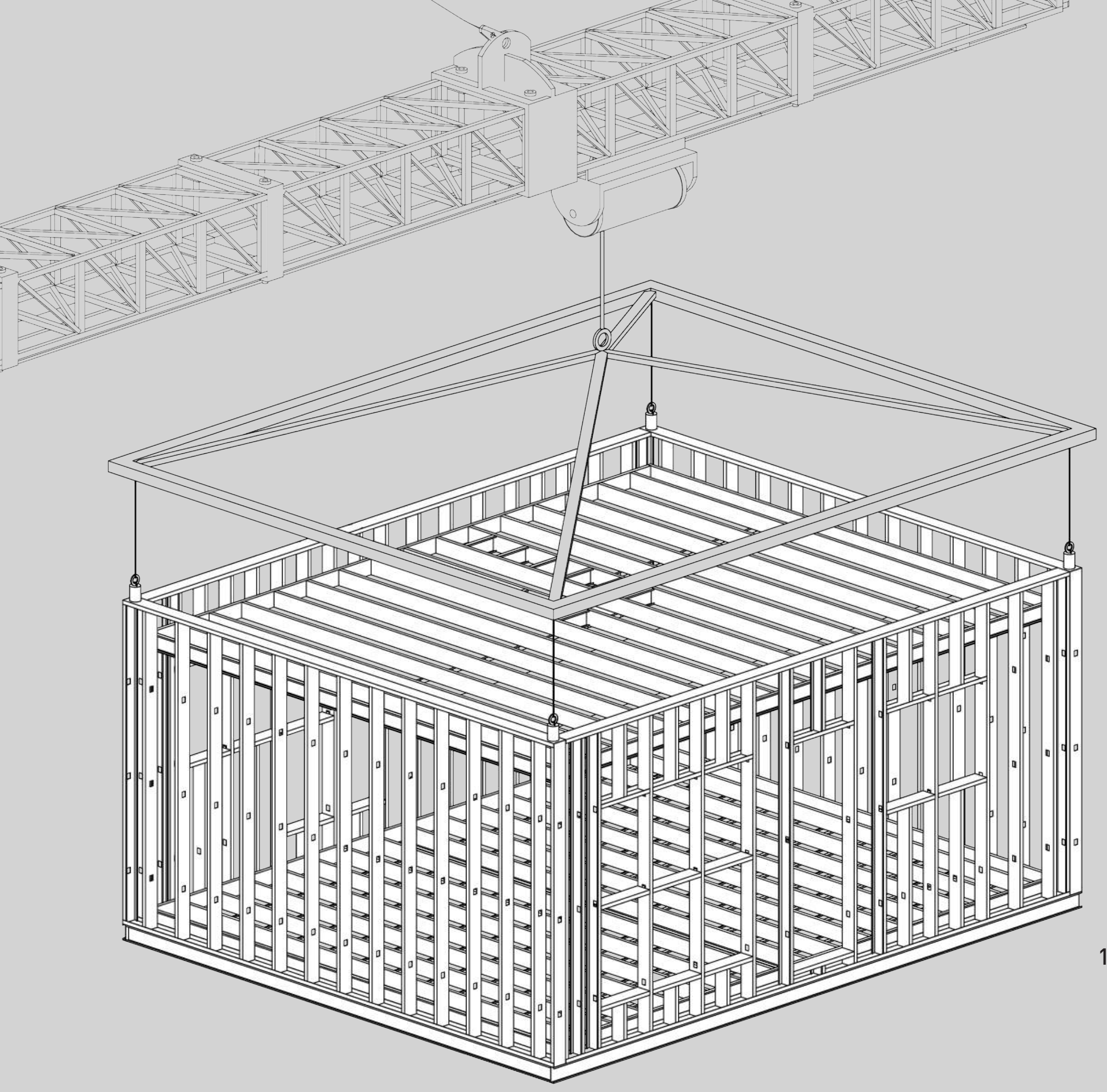

The one bedroom unit is less than 400 square feet and costs approximately $\$ 40,000$ in construction materials. The size and shape of the unit is derived from the existing structural system of the long shed like buildings that formerly housed the hot and cold mills of the steel plant. Nevertheless, the unit itself is fundamentally independent; its envelope and steel structure are self sufficient apart from the existing industrial frame. Minimal adaptation can allow the unit to exist apart from the factory. 


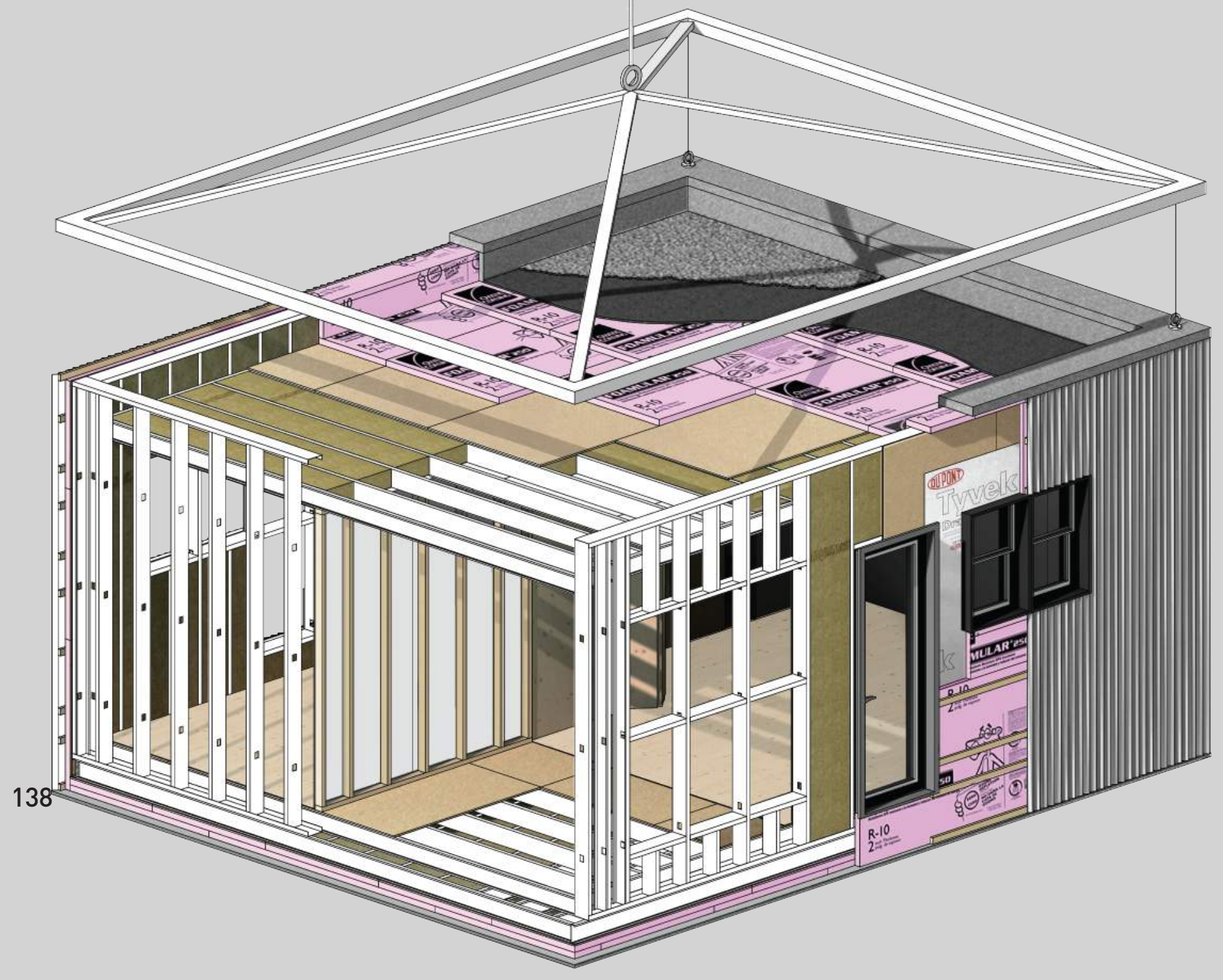




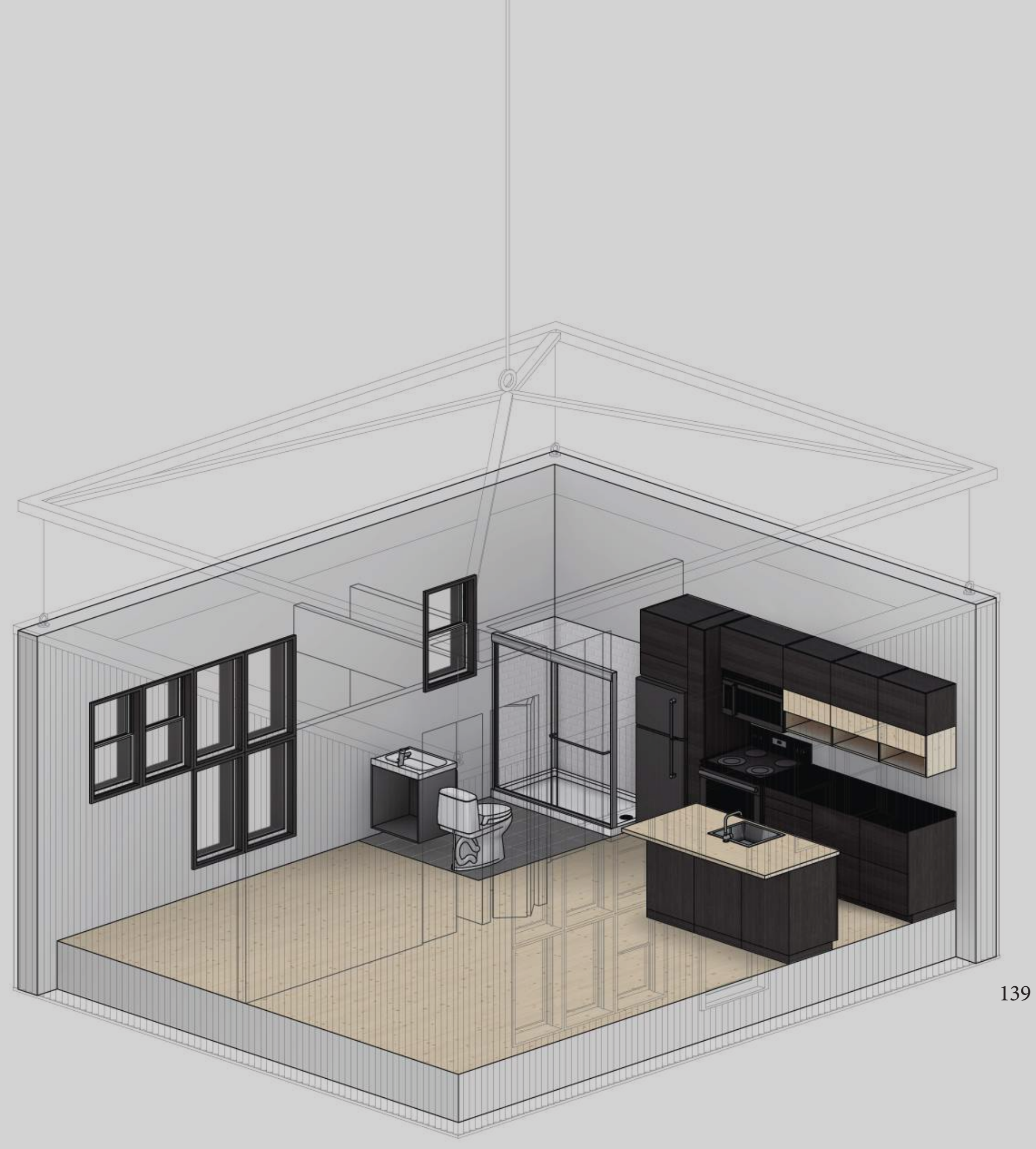





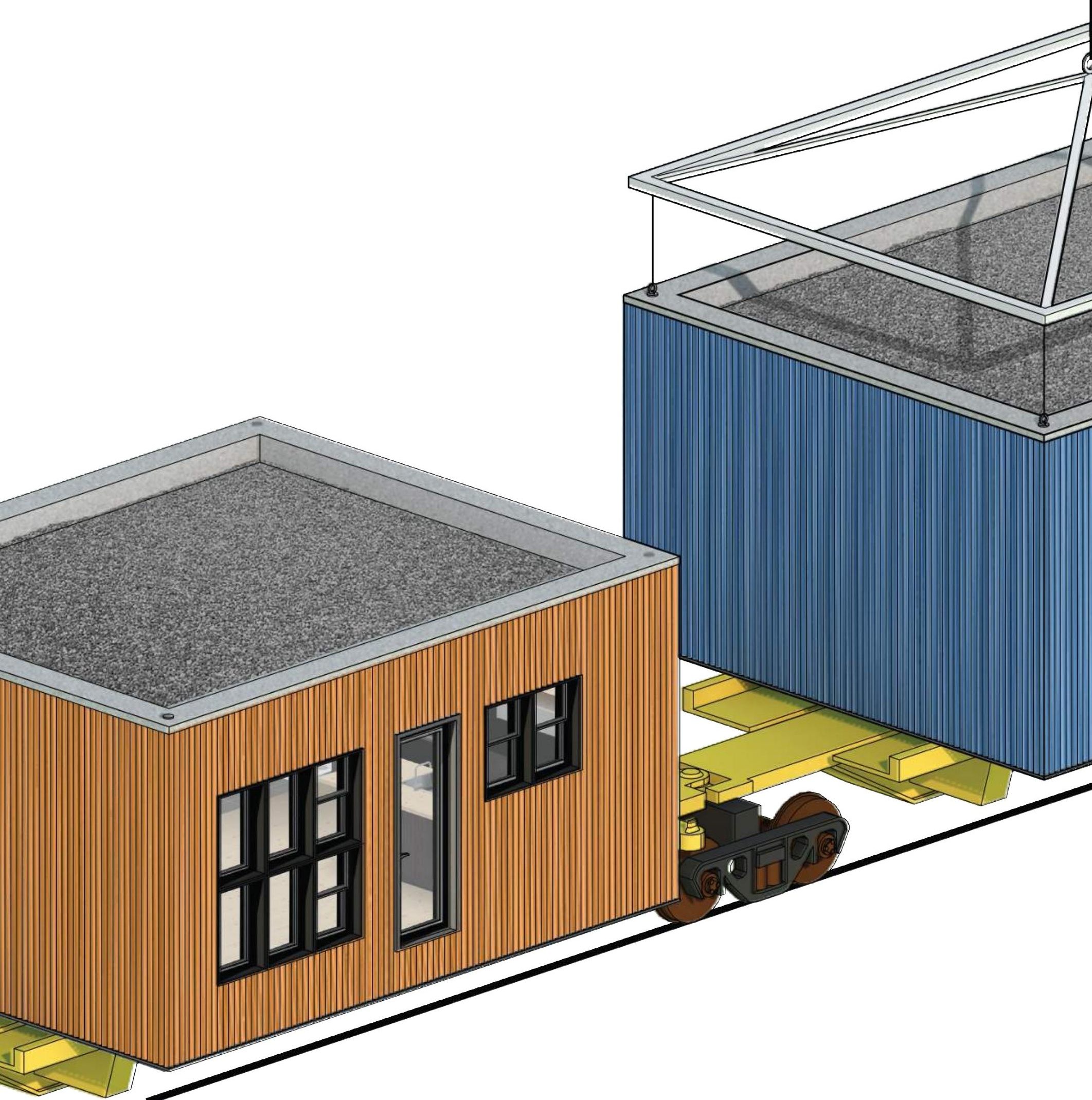




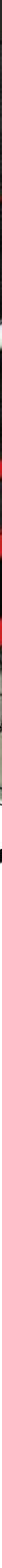




\section{Unit Sizes and Prices}

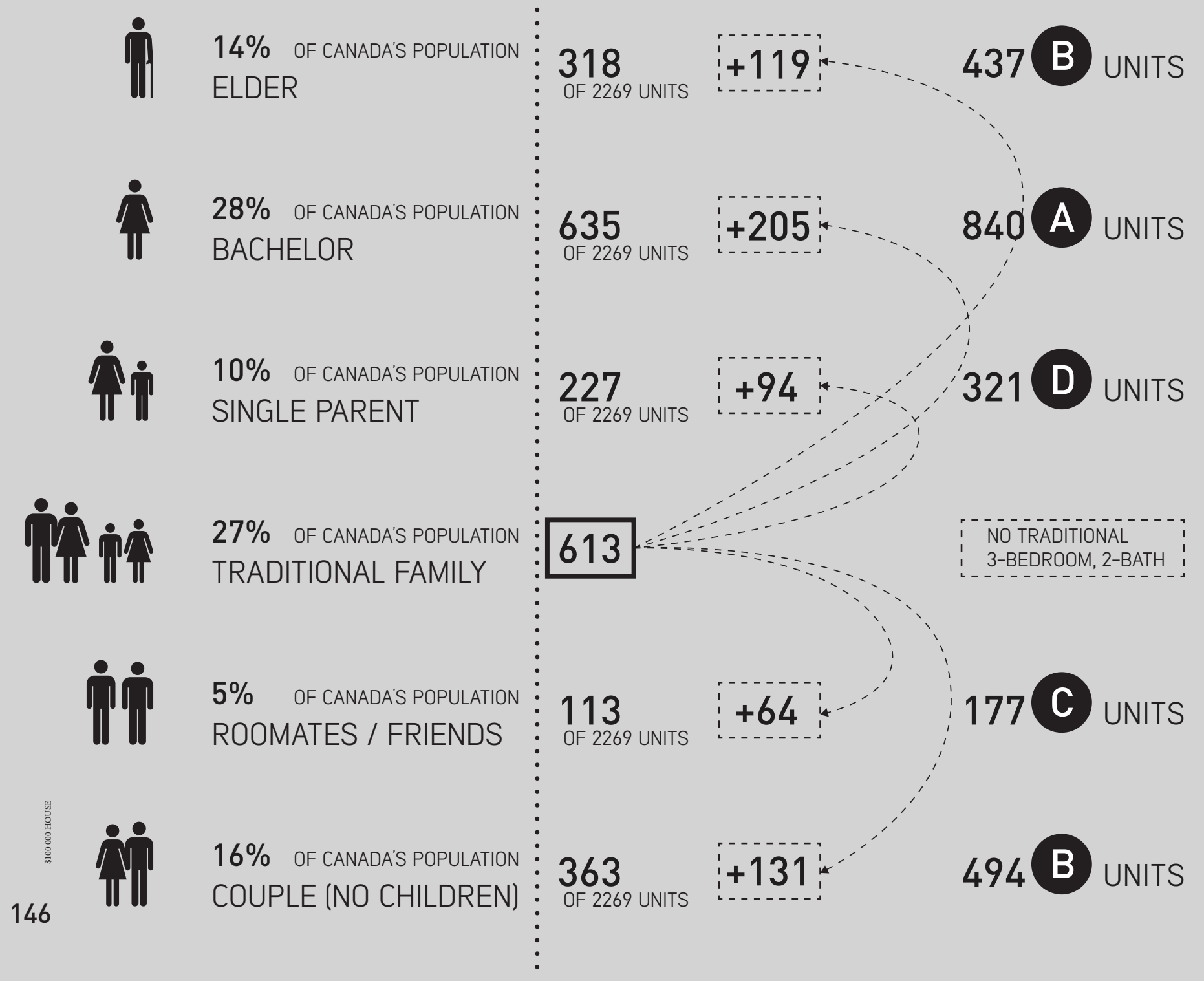

Units range in size from one-bedroom to two bedrooms plus a den. The majority of family types that cannot afford adequate housing in the Hamilton market are those with a single person income, individuals living alone or single-parent families. For that reason the unit designs are focused on family types that do not require the traditional 3-bedroom, 2-bathroom houses that define the Hamilton housing market. Approximately 40\% of Canada's population only requires a single bedroom household, 28\% of Canada's population are individuals living alone, $16 \%$ are couples with no children and $14 \%$ of the population are retired individuals or couples. 

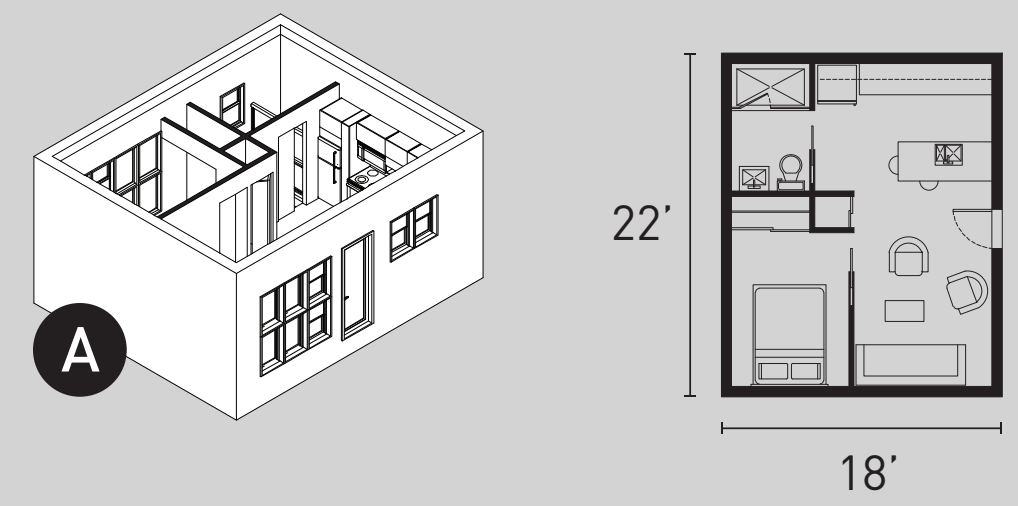

\section{BEDROOM}

TOTAL AREA : 396 ${ }^{\prime}$

MATERIAL PRICE : \$40 840

SALE PRICE : $\$ 100000$
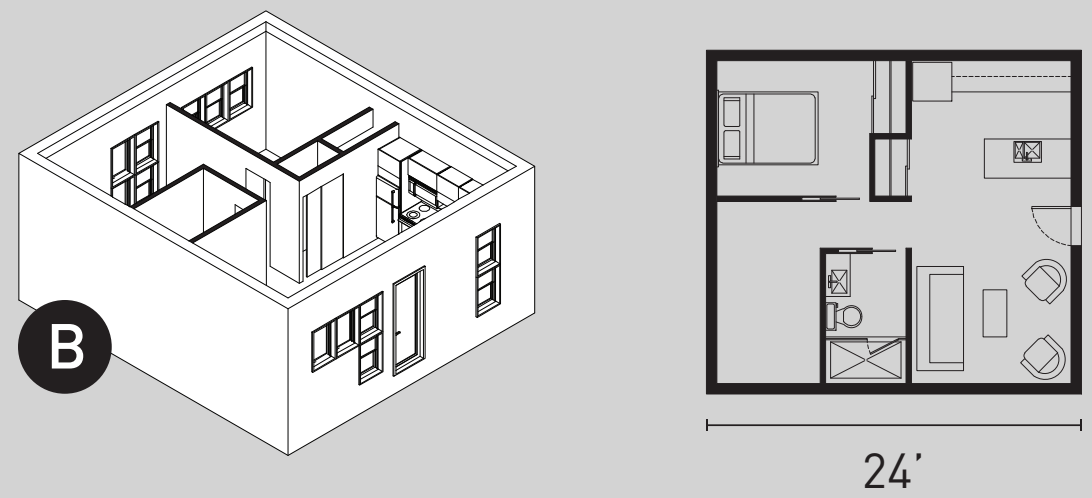

\section{BEDROOM + DEN}

TOTAL AREA : 432 $\square^{\text {' }}$

MATERIAL PRICE : \$44 552

SALE PRICE : $\$ 110000$

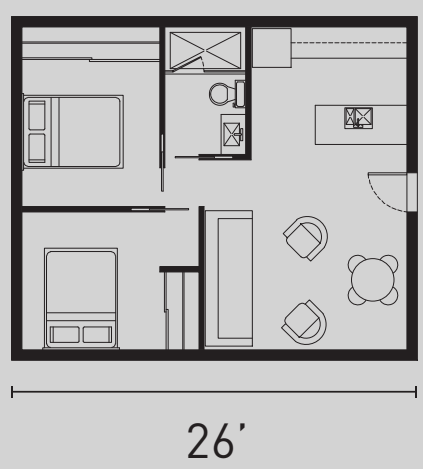

\section{BEDROOM \\ TOTAL AREA : 468ם ' \\ MATERIAL PRICE : \$48 265 \\ SALE PRICE : $\$ 118000$}
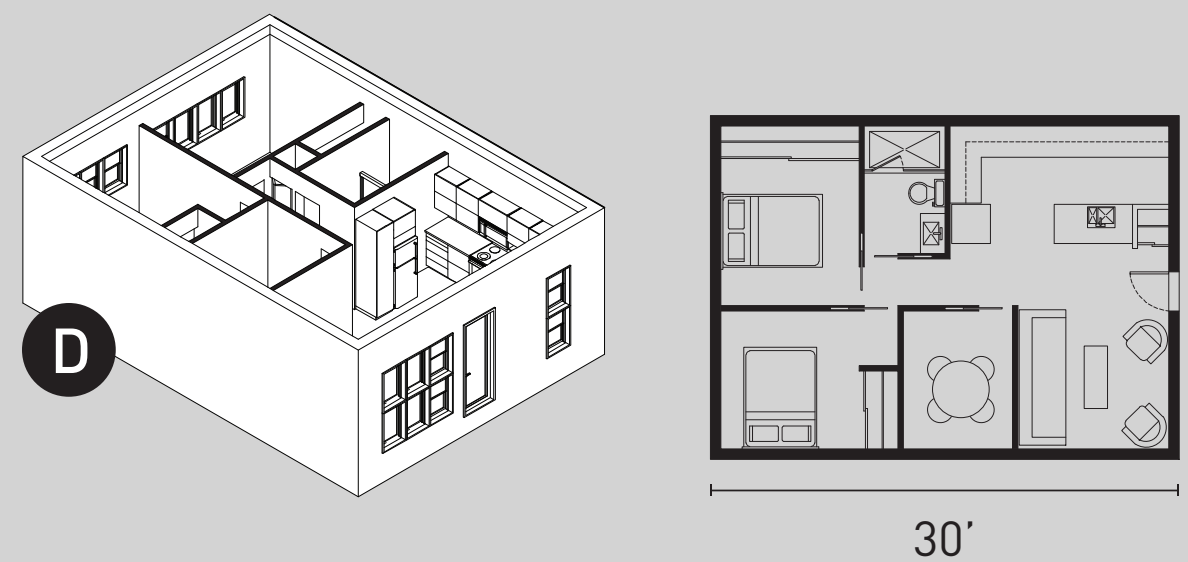

\section{BEDROOM + DEN}

TOTAL AREA : 540 ${ }^{\text {' }}$

MATERIAL PRICE : $\$ 55690$

SALE PRICE : \$137000

* MATERIAL COST/ ${ }^{\prime}: \$ 103.13$

* SALE COST/ $\square$ ' : \$252.52 

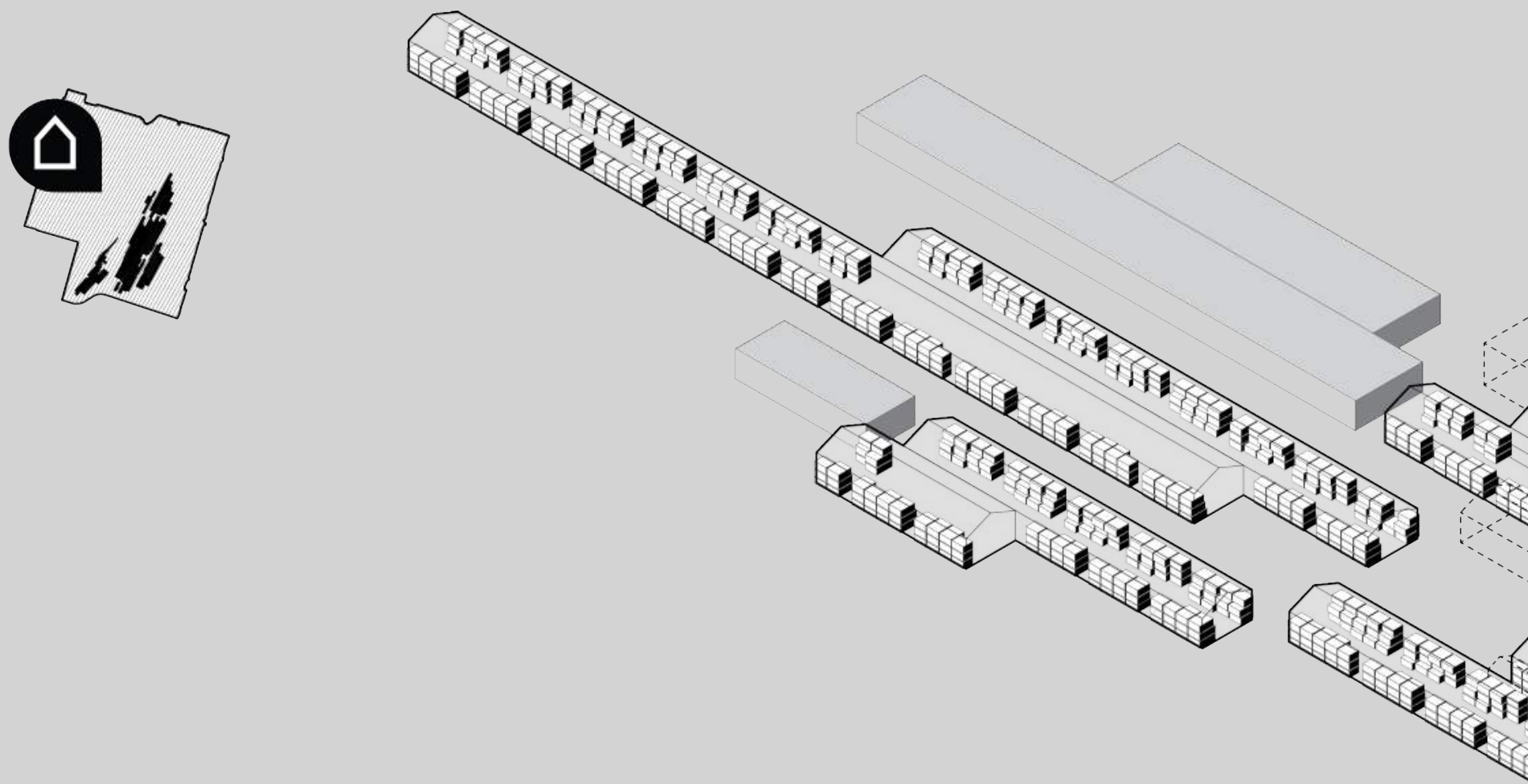

\section{AFFORDABLE 975 MARKET VALUE 2269 TOTAL UNITS}

The new design of the industrial sheds can hold roughly 2,269 units, for obvious reasons not all units can provide social housing. With the site's economic plan for development and public private partnership, a balance of market housing will provide funding to support the integration of social housing. The City of Hamilton's Official Plan outlines that $57.7 \%$ of all new ownership housing will be affordable to low and moderate income households, including housing with supports. Their suggested methods to achieve this target include controlling the housing market, low down-payment options, first-time buyer program and support services. The remaining $43.3 \%$ of new ownership housing will not be affordable to individuals with a lower income. ${ }^{2}$ For the housing adaptation of Stelco, 1,294 units will be affordable to the low-income families and 975 units will be market housing to supplement the low profitability from selling affordable units. 


\section{Site Application}

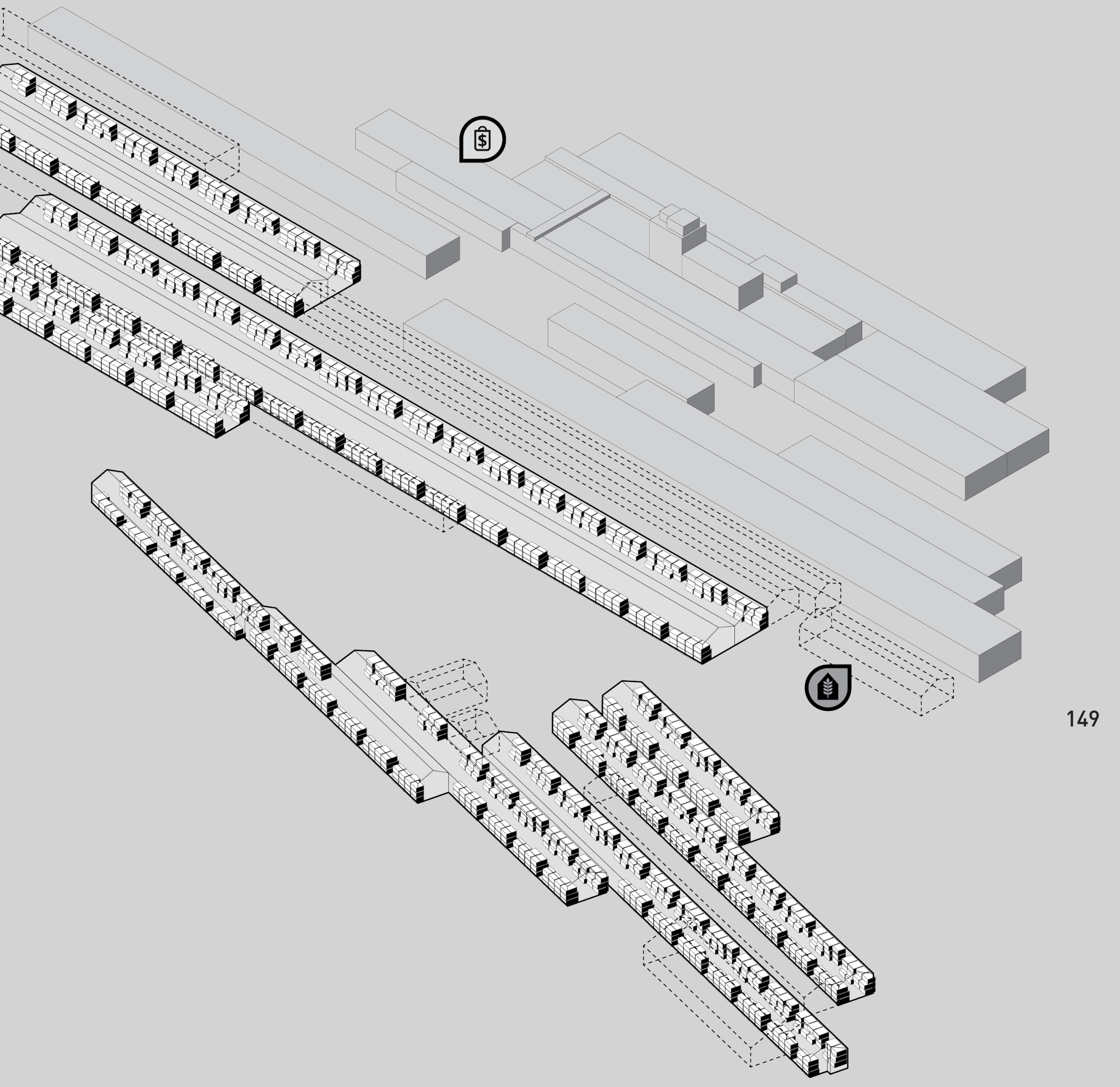



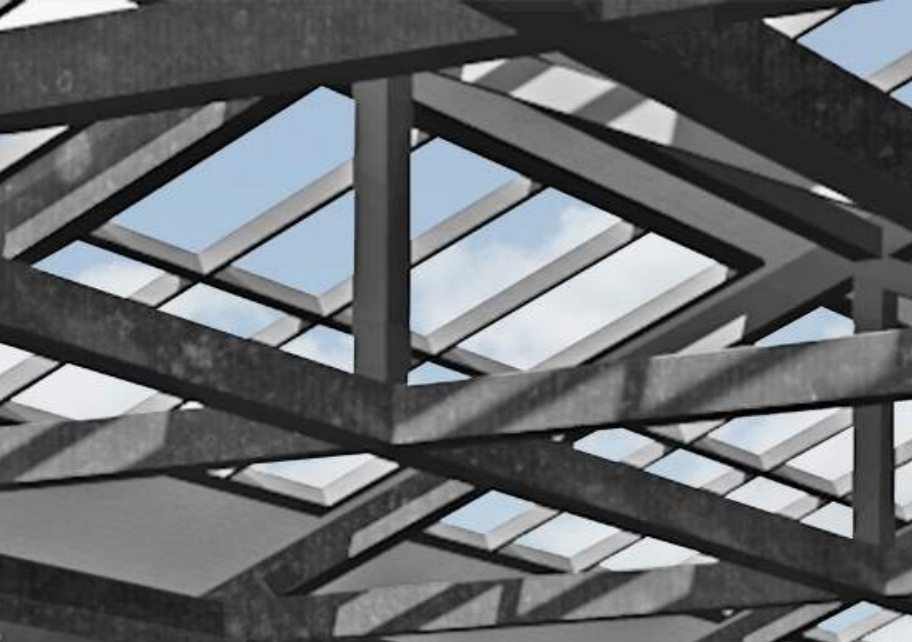

3
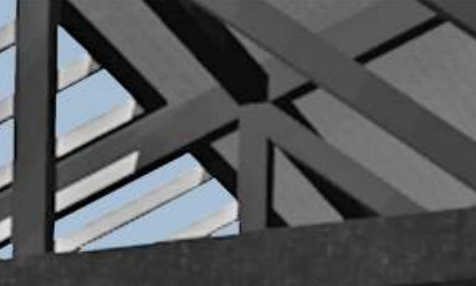

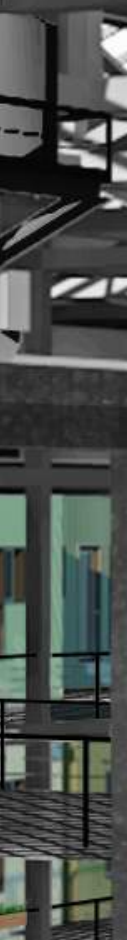

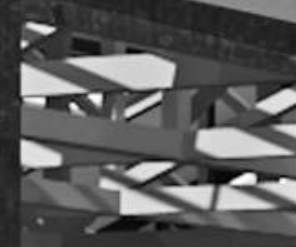

>

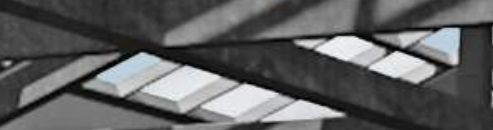

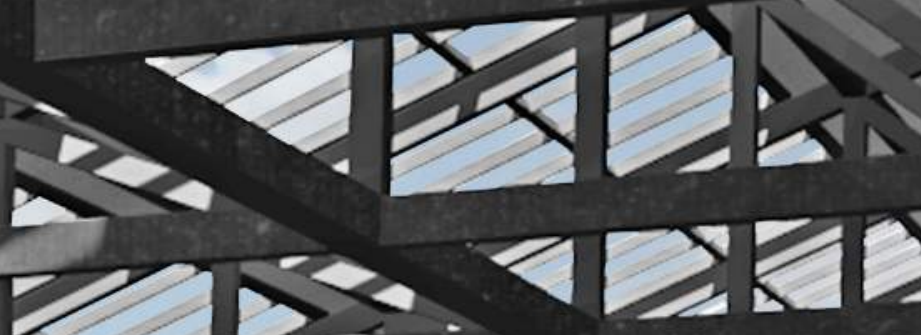

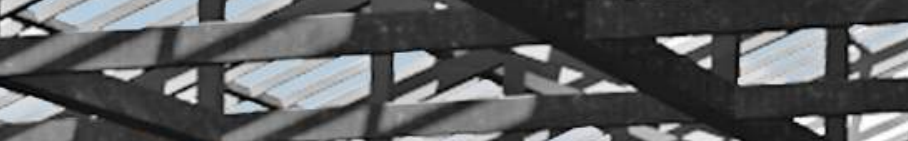

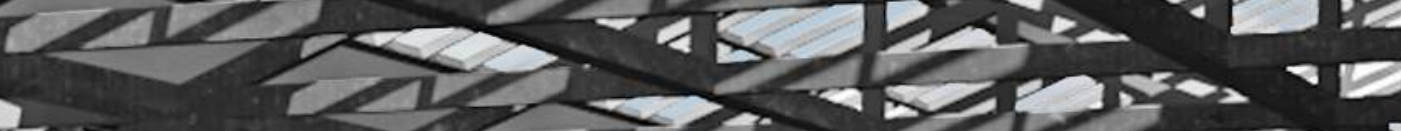

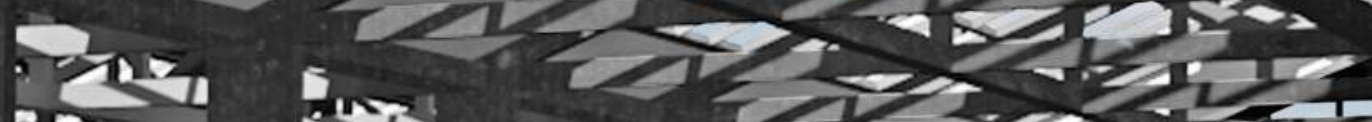

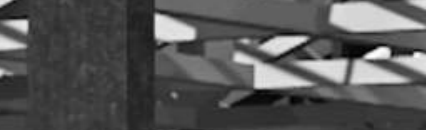

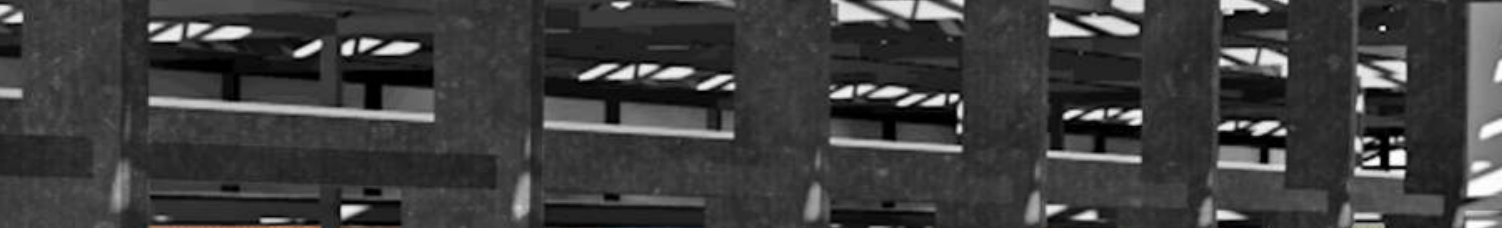
एक $45 \mathrm{~s} \rightarrow \frac{1}{2}$

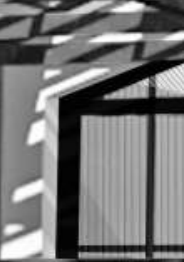

$2=\frac{1}{2}$
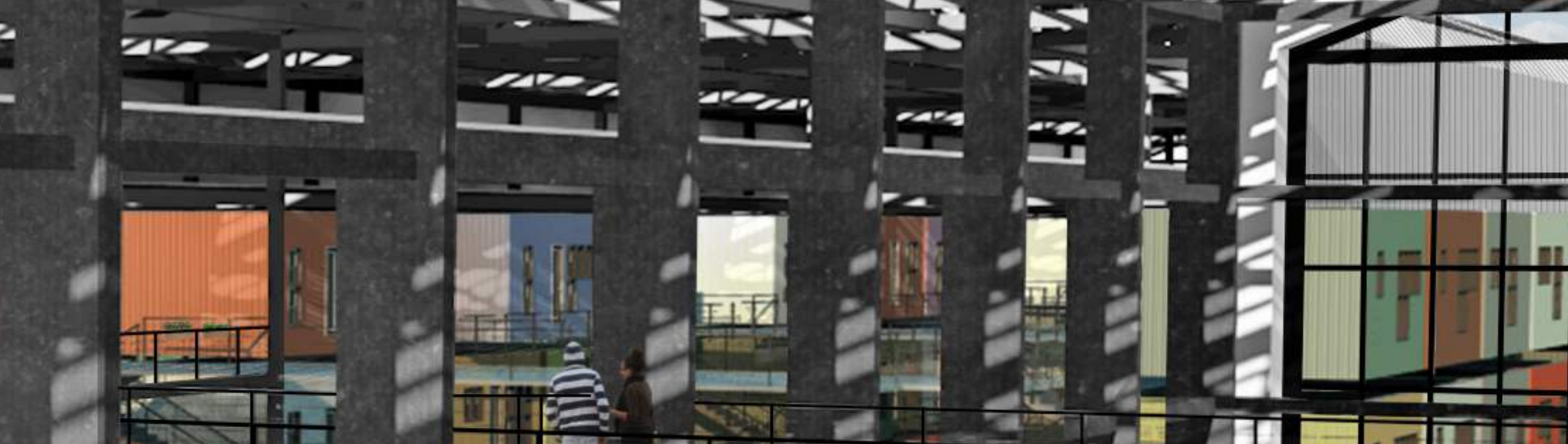
1 "Appointments to CMHC Board of Directors," Canada Mortgage and Housing Corporation, accessed March 16,

2015, http://www.cmhc-schl.gc.ca/en/corp/nero/nere/2015/2015-02-06-1300.cfm.

2 "Urban Hamilton Official Plan," The City of Hamilton (February 2014): B.3.6, accessed March 26, 2015, http:// www.hamilton.ca/NR/rdonlyres/0A939735-8827-4D79-8C54-B01970515106/0/UHOPVol1PoliciesrevOct2013.pdf. 

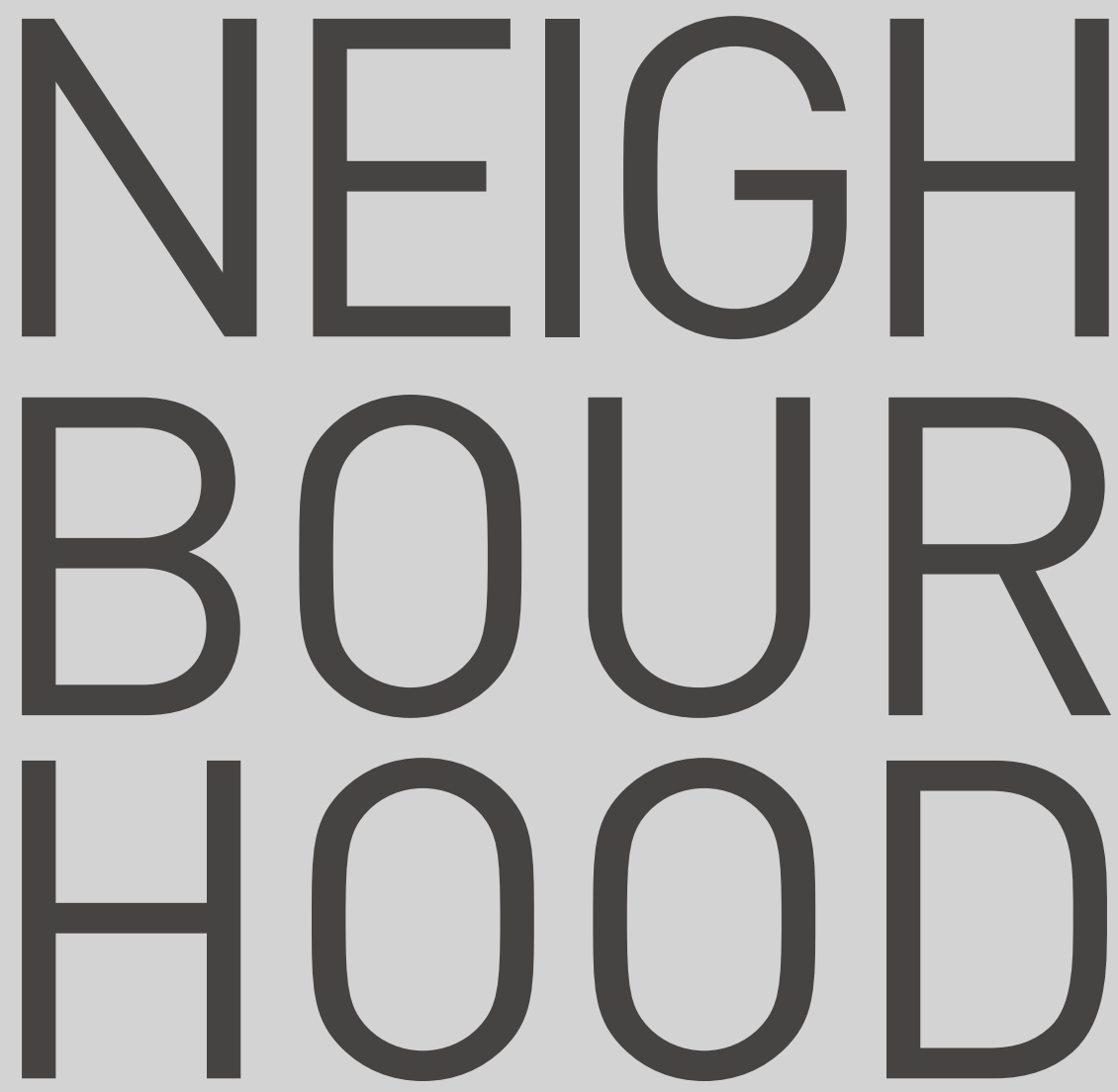

154 


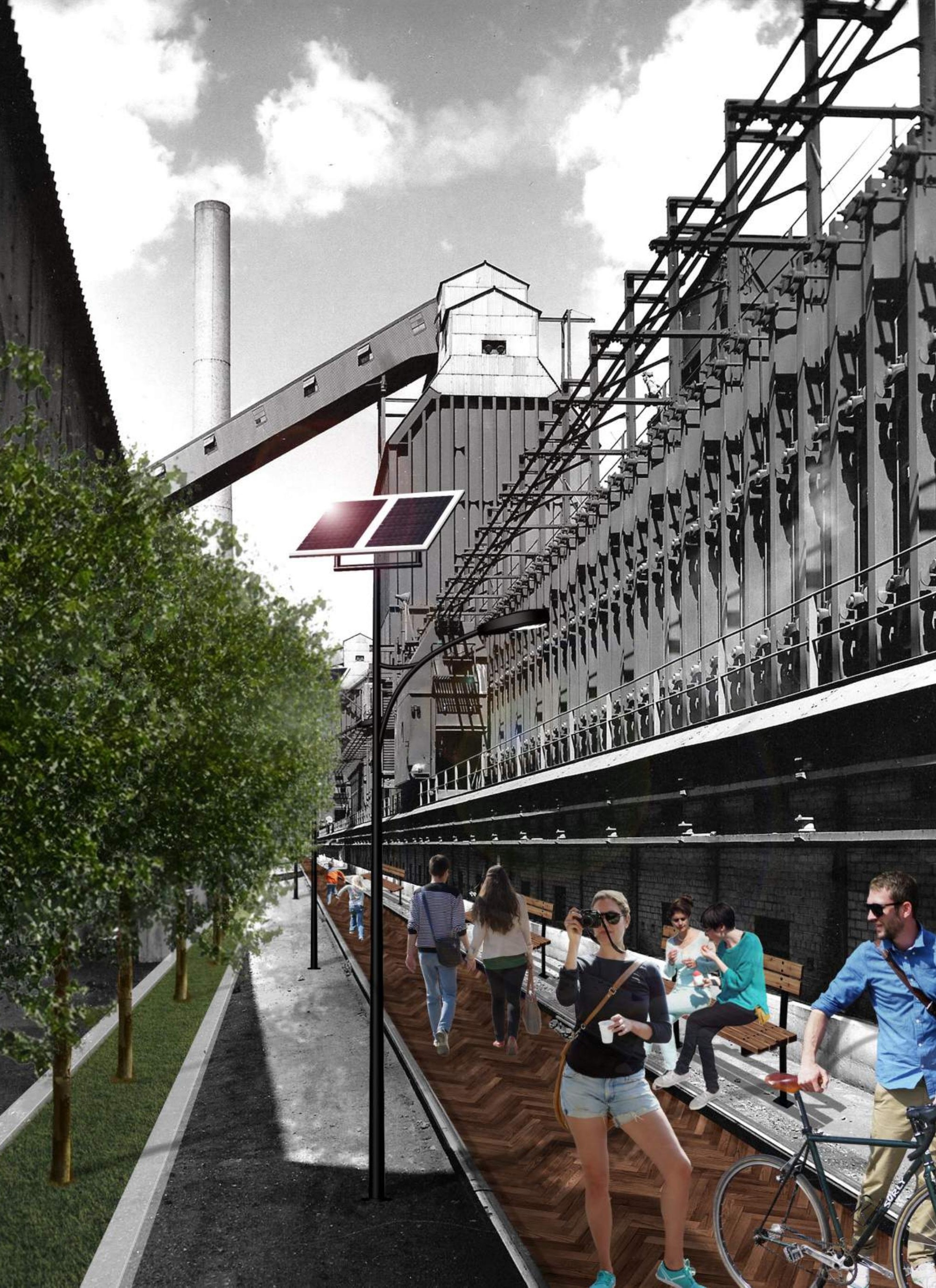


Post-industrial sites are the future of Canadian rustbelt cities. These cities provide new opportunities for citizens to lead in the development of their community. Previous success as an industrial based economy has provided a strong sense of cultural identity, a comparatively low cost of living and an extensive inventory of industrial ruins. Hamilton is a present case of this social and economic transition as a post industrial city. Moreover it is fervently seeking urban renewal motivated by the influx of out of town buyers from the Greater Toronto Area seeking. The growing inventory of brownfields and the demand for housing are influential factors in this season of urban development. Although Hamilton's recovery from a deindustrialized economy has begun on a local scale, much of its waterfront continues to be plagued with the economic and environmental side effects of heavy industry.

Steelcity Living is the development of the U.S. Steel Canada plant along Hamilton's waterfront. The project seeks to reoccupy the site from private industry to public habitation through the adaptation, remediation and preservation of its industrial ruins for a new model of mixed use programming. The project focuses on a new type of affordable housing, alleviating the pressure of government assisted living with homeownership for low-income individuals. The $\$ 100,000$ house is enriched via the remediation and preservation of Stelco's industrial ruins and will contribute to the recognition and rebuilding of Hamilton's cultural past.

Referencing the site's historical past as the Canadian steel giant, Steelcity Living on the site of U.S. Steel Canada has the potential to set a national precedent for affordable homeownership and brownfield development. 


\section{LIST OF ILLUSTRATIONS}

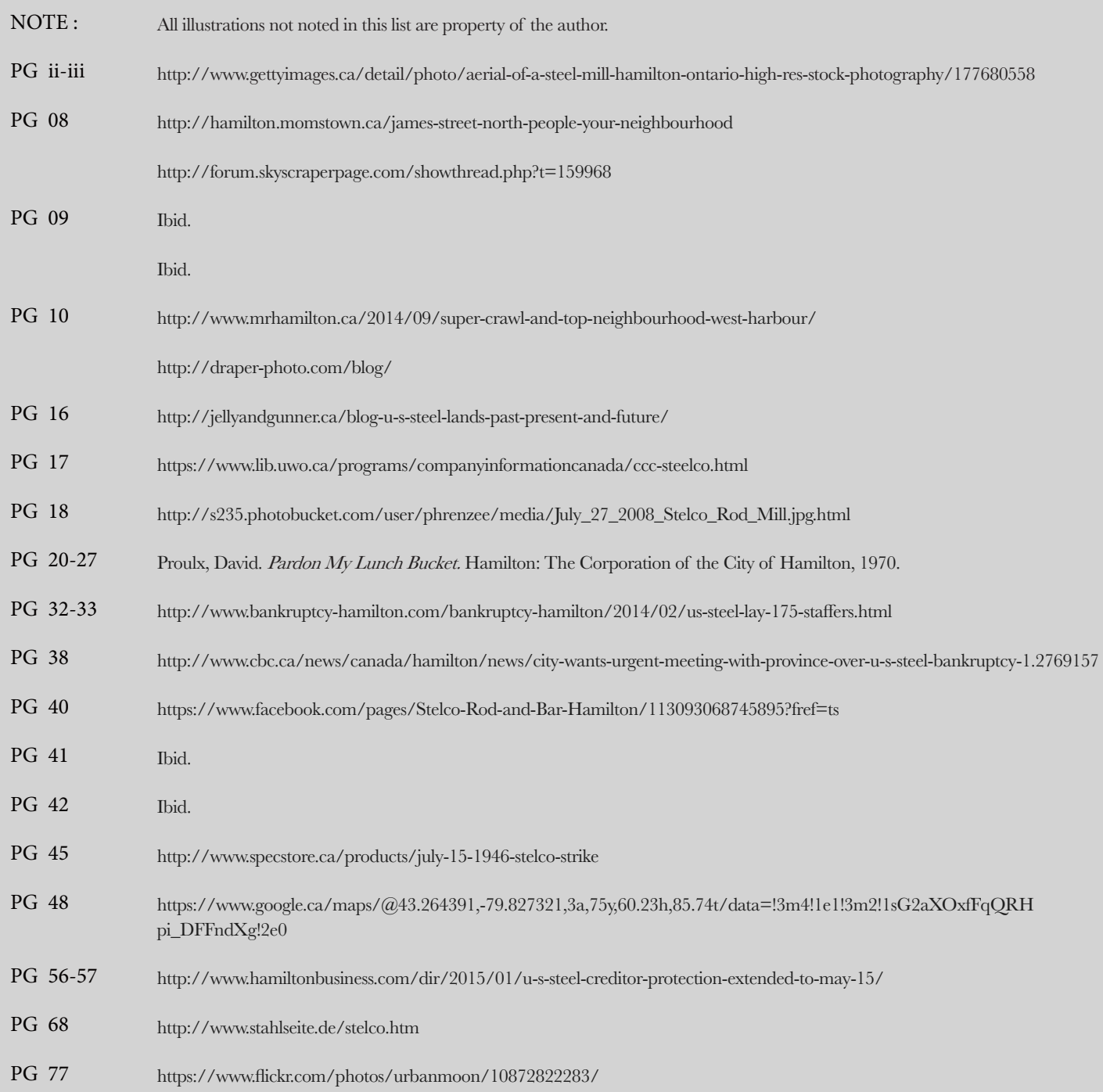




\section{LIST OF TABLES}

PG 107 Dillon Consulting Limited, “Growth Related Integrated Development Strategy,” Hamilton (2006): 6, accessed March 16, 2015, http:// www.hamilton.ca/NR/rdonlyres/81E38F84-D751-4364-93B7-C8D3D4D23F1E/0/Final_Growth_Report_May2006R.pdf.

PG 108 Ibid

PG 109 Canada. "Census Metropolitan Area of Hamilton, Ontario.” Statistics Canada. Accessed March 16, 2015. http://www.statcan.gc.ca/ daily-quotidien/140814/dq140814a-eng.htm.

PG 110 Housing Market Outlook," CMHC (Fall 2014): 8, accessed March 16, 2015, http://www.cmhc-schl.gc.ca/odpub/ esub/64303/64303_2014_B02.pdf.

GMHC “Rental Market Report," Hamilton and Brantford CMA's (2013). Accessed March 16, 2015. http://www.cmhc-schl.gc.ca/ odpub/esub/64391/64391_2013_A01.pdf.

PG 111 City of Hamilton, "Housing \& Homeless Action Plan," Hamilton (2013): 5, accessed March 16th, 2015, http://www.hamilton.ca/NR/ rdonlyres/42233E9F-C5AD-4E06-9F2C-1711C0FD32F5/0/HHAP_Summary.pdf.

PG 112 "Housing Now," CMHC January 2015): 3, accessed March 16, 2015, http://www.cmhc-schl.gc.ca/odpub/esub/64227/64227_2015_ M01.pdf?fr=1424475347141.

PG 114

Dillon Consulting Limited, “Growth Related Integrated Development Strategy,” Hamilton (2006): 6, accessed March 16, 2015, http:// www.hamilton.ca/NR/rdonlyres/81E38F84-D751-4364-93B7-C8D3D4D23F1E/0/Final_Growth_Report_May2006R.pdf.

PG 124-124 CMHC. "Homebuying Tools - Calculators." Accessed December 8, 2014. http://www.cmhc-schl.gc.ca/en/co/buho/buho_005.cfm.

PG 96-99 Dye, Rebekah, Andrea Parker, Kaja Kühl, and Jay Tsai, "Brownfields and Greenfields." Youarethecity (2011): pg. Accessed March 15, 2015. http://www.youarethecity.com/work/brownfields-to-greenfields/.

PG 138 Canada. Statistics Canada. http://www.statcan.gc.ca. 


\section{BIBLIOGRAPHY}

Allen, Smout. Augmented Landscapes. New York: Princeton Architectural Press, 2007.

Arendt, Hannah. The Human Condition. Chicago: University of Chicago Press, 1958.

Arnold, Steve. "Does the former Stelco have a future in Hamilton?" The Spec, February 04, 2012. Accessed December 18, 2014. http://www.thespec.com/ news-story/2223072-does-the-former-stelco-have-a-future-in- hamilton-/.

Arnold, Steve. "Stelco Timeline: A story of booms, busts and back again." The Spec, August 27, 2007. Accessed March 14, 2015. http://www.thespec.com/ news-story/2143631-stelco-timeline-a-story-of-booms-busts-and-back-again/.

Arnold, Steve. "U.S. Steel Canada files for bankruptcy protection." The Spec, September 17, 2014. Accessed September 17, 2014. http://www.thespec.com/ news-story/4863643-u-s-steel-canada-filing-for-bankruptcy-protection/.

Arnold, Steve. "U.S. Steel says it can't finance operations without creditor protection." The Spec, September 18, 2014. Accessed September 18, 2014. http:// www.thespec.com/news-story/4865160-canadian-plants-drain-2-billion-u-s-steel/.

Bernard Ward, Harold. Hamilton, Ontario, as a manufacturing centre... Chicago: The University of Chicago Libraries, 1937.

Buist, Steve. "U.S. Steel's pension shortfall raises concerns." The Spec, September 18, 2014. Accessed September 18, 2014. http://www.thespec.com/newsstory/4865604-u-s-steel-s-pension-shortfall-raises-concerns/.

Burke, Edmund, On the Sublime and Beautiful. New York: P.F. Collier \& Son, 1909-14. Vol. XXIV.

Canada. "Census Metropolitan Area of Hamilton, Ontario." Statistics Canada. Accessed March 16, 2015. http://www.statcan.gc.ca/daily-quotidien/140814/dq140814a-eng.htm.

Carter, Adam. "What's next for Hamilton's brownfields?” CBC Hamilton, July 16, 2013. Accessed March 30, 2015. http://www.cbc.ca/news/canada/hamilton/news/what-s-next-for-hamilton-s-brownfields-1.1411099.

Chodikoff, Ian. "Bricks and Mortar." Canadian Architect, January 2007. Accessed December 19, 2013. http://dtah.com/wp-content/uploads/2012/05/2007-01_CanArchitect_Bricks-and-Mortar.pdf.

Christensen, Peter. Home Delivery. New York: Museum of Modern Art, 2008.

City of Hamilton. "Housing \& Homeless Action Plan," Hamilton (2013). Accessed March 16th, 2015. http://www.hamilton.ca/NR/rdonlyres/42233E9FC5AD-4E06-9F2C-1711C0FD32F5/0/HHAP_Summary.pdf.

City of Hamilton. "Nine Directions to Guide Development," Urban Hamilton Official Plan (February 2014): B.3.6. Accessed March 26, 2015, http://www. hamilton.ca/NR/rdonlyres/0A939735-8827-4D79-8C54-B01970515106/0/UHOPVol1PoliciesrevOct2013.pdf.

CMHC. "Canada's Economic Action Plan Offers Incentives for Homeownership." Accessed December 6, 2014. http://www.cmhc-schl.gc.ca/en/co/buho/ buho_008.cfm.

CMHC. "Homebuying Tools - Calculators." Accessed December 8, 2014. http://www.cmhc-schl.gc.ca/en/co/buho/buho_005.cfm.

CMHC. "Housing Now," Hamilton and Brantford CMA's (January 2015): 3, accessed March 16, 2015, http://www.cmhc-schl.gc.ca/odpub/ esub/64227/64227_2015_M01.pdf?fr=1424475347141.

CMHC. "Housing Market Outlook." Hamilton and Brantford CMA’s (Spring 2013). Accessed March 16, 2015. http://www.cmhc-schl.gc.ca/odpub/ esub/64303/64303_2013_B01.pdf.

CMHC. "Housing Market Outlook." Hamilton and Brantford CMAss (Fall 2014). Accessed March 16, 2015. http://www.cmhc-schl.gc.ca/odpub/ esub/64303/64303_2014_B02.pdf.

CMHC "Rental Market Report," Hamilton and Brantford CMA's (2013). Accessed March 16, 2015. http://www.cmhc-schl.gc.ca/odpub/ esub/64391/64391_2013_A01.pdf.

Crawford, Margaret. Building the Workingman's Paradise. London, New York: Verso, 1995.

Deborah Sawyer and Erin James-Abra. "Stelco Inc." The Canadian Encyclopedia, October 20 2014. Accessed 3 February 2015. http://www.thecanadianencyclopedia.ca/en/article/stelco-inc/.

Dillon Consulting Limited. "Growth Related Integrated Development Strategy." Hamilton(2006). Accessed March 16, 2015, http://www.hamilton.ca/NR/ rdonlyres/81E38F84-D751-4364-93B7-C8D3D4D23F1E/0/Final_Growth_Report_May2006R.pdf.

“The Distillery District: a shot of history.” Distillery District Heritage Website, 2007. Accessed December 18, 2013. http://www.distilleryheritage.com/inbrief. html. 
Dye, Rebekah, Andrea Parker, Kaja Kühl, and Jay Tsai, "Brownfields and Greenfields.” Youarethecity(2011): pg. Accessed March 15, 2015. http://www. youarethecity.com/work/brownfields-to-greenfields/.

Ebers, Malko. Shrinking Cities, The Hidden Challenge. Germany: GRIN Verlag, 2005.

Edensor, Tim. Industrial Ruins: Space, Aesthetics and Materiality. New York: Berg, 2005.

EPA, Office of Solid Waste and Emergency Response (2001): Brownfield Technology Primer: Selecting and Using Phytoremediation for Site Cleanup http:// nepis.epa.gov.

EPA. “Soil Contamination.” Accessed March 15, 2015. http://www.epa.gov/superfund/students/wastsite/soilspil.htm.

"Evergreen Brick Works / Diamond Schmitt Architects." Arch Daily, June 11, 2012. Accessed December 19, 2013. http://www.archdaily.com/?p=241503.

Gadamer, Hans Georg. The Relevance of the Beautfiul. Quebec: McGill-Queens University Press, 1999.

Hayden, Dolores. Seven American Utopias. London: MIT Press, 1981.

Keenan, Greg. "US Steel ends an era in Hamilton." The Globe and Mail, October 29, 2013. Accessed December 18, 2013. http://www.theglobeandmail. com/report-on-business/us-steel-to-shut-down-hamilton-works- ceo-says/article15142440/.

Kilburn, William. 24 The Elements Combined, A history of The Steel Company of Canada. Toronto, Vancouver: Clarke, Irwin \& Company Limited, 1960

Kirkwood, Niall. Manufactured Sites. London \& New York: Spon Press, 2001.

Le Corbusier. Towards a New Architecture. London:J. Rodker, 1931.

Leatherbarrow, David. Uncommon Ground. London: MIT Press, 2000.

Nye, David E. American Technological Sublime. London: MIT Press, 1994.

Macleod, Meredith. "Dofasco brightens a bleak week for steel." The Spec, November 08, 2013. Accessed December 18, 2014. http://www.thespec.com/ news-story/4199638-dofasco-brightens-a-bleak-week-for-steel/.

McKay, Jock. "From the Beginning." Stelco R\&D History. Accessed 12 March 2015. http://motem.ca/FromTheBeginning.pdf

Mumford, Lewis. Technics and Civilization. New York: Harcourt, Brace \& World, Inc., 1934

O'Connell. "In the Shadows of steel." September 12, 2013. CBC Radio. Accessed 17 Sept 2014. http://www.cbc.ca/ideas/episodes/2013/09/12/in-theshadow-of-steel/\#igImgId_81661.

Pérez-Gómez, Alberto. Chora: The Space of Architectural Representation. Montreal: McGill-Queen’s University Press, 1999.

Peter Latz, "The Metamorphosis of the 20th Century's Landscape,” March 1st 2004, Lecture at the University of California, Berkeley.

Proulx, David. Pardon My Lunch Bucket. Hamilton: The Corporation of the City of Hamilton, 1970.

Radwanski, Adam. "Rust Belt revival: Lessons for southwest Ontario from America's industrial heartland." The Globe and Mail, January 16, 2015. Accessed March 30, 2015. http://www.theglobeandmail.com/news/national/rust-belt-revival-lessons-for-southwestern-ontario-from-americas-industrial-heartland/ article22489159/.

Rossi, Aldo. 'The Structure of Urban Artifacts' in The Architecture of the City," (pp. 29-61).

Samantha Craggs. "City increases Hamilton artist grants or first time in 15 years." CBC Hamilton, March 24, 2015. Accessed March 30, 2015. http://www. cbc.ca/news/canada/hamilton/news/city-increases-hamilton-artist-grants-for-first-time-in-15-years-1.3007072.

USDA, United States Department of Agriculture : Phytoremediation of Chicago's Brownfields: Consideration of Ecological Approaches and Social Issues (Accessed: Feb 18, 2015) http://www.nrs.fs.fed.us/urban/calumet/local-resources/downloads/westphal_isebrands_phytoremediation.pdf.

Warren, Marty and Leo W. Gerard. "Canada Needs a Steel Strategy." Financial Post, November 5, 2013. Accessed March 16, 2015. http://business.financialpost.com/2013/11/05/canada-needs-a-steel-strategy/.

Weilacher, Udo. Syntax of Landscape. The Landscape Architecture by Peter Latz and Partners. Basel, Berlin, Boston: Birkhauser Publisher, 2008.

Young, Gordon. Tear-Down: Memoir of a Vanishing City. London: University of California Press, 2013. 